\title{
Using the NOABL Flow Model and Mathematical Optimization as a Micrositing Tool
}

H. L. Wegley

J. C. Barnard

November 1986

Prepared for the U.S. Department of Energy under Contract DE-AC06-76RLO 1830

Pacific Northwest Laboratory Operated for the U.S. Department of Energy by Battelle Memorial Institute 


\title{
DISCLAIMER
}

This report was prepared as an account of work sponsored by an agency of the United States Government. Neither the United States Government nor any agency thereof, nor Battelle Memorial Institute, nor any of their employees, makes any warranty, expressed or implied, or assumes any legal liability or responsibility for the accuracy, completeness, or usefulness of any information, apparatus, product, or process disclosed, or represents that its use would not infringe privately owned rights. Reference herein to any specific commercial product, process, or service by trade name, trademark, manufacturer, or otherwise, does not necessarily constitute or imply its endorsement, recommendation, or favoring by the United States Government of any agency thereof, or Battelle Memorial Institute. The views and opinions of authors expressed herein do not necessarly state or reflect those of the United States Government or any agency thereof, or Battelle Memorial Institute.

\author{
PACIFIC NORTHWEST LABORATORY \\ operated by \\ BATTELLE \\ for the \\ UNITED STATES DEPARTMENT OF ENERGY \\ under Contract DE-AC06-76RLO 1830
}

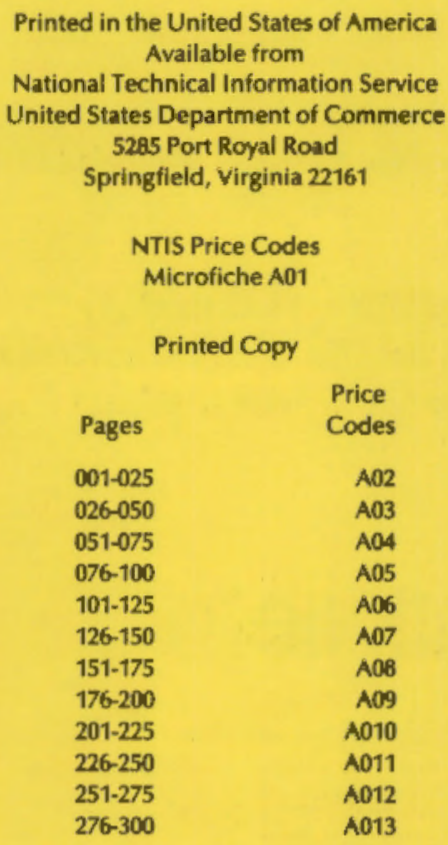



H. L. Wegley ${ }^{(a)}$
J. C. Barnard

November 1986

Prepared for

the U.S. Department of Energy

under Contract DE-AC06-76RLO 1830

Pacific Northwest Laboratory

Richland, Washington 99352

(a) Present Affiliation: Ultrasystems Defense and Space Systems, Inc. Kent, washington 98032 



\section{SUMMARY}

This report describes the use of an improved mass-consistent model that is intended for diagnosing wind fields in complex terrain. The model was developed by merging an existing mass-consistent model, the NOABL model, with an optimization procedure. The optimization allows objective calculation of important model input parameters that previously had been supplied through guesswork; in this manner, the accuracy of the calculated winds has been greatly increased.

The report covers such topics as the software structure of the model, assembling an input file, processing the model's output, and certain cautions about the model's operation. The use of the model is illustrated by a test case. 
. 


\section{ACXNOWLEDGMENTS}

The authors greatly appreciate the assistance of many people in the preparation of this user's guide: Dr. L. L. Wendell, for his constant encouragement during the development of the model; Laurel Grove and Dr. D. C. Powe11, for their excellent reviews of the draft manuscript; Gene Gower, for his help in preparing the appendices, and Rosemary Ellis, who cannot be thanked enough for her usual efficient help in assembling this manuscript. 


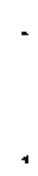




\section{CONTENTS}

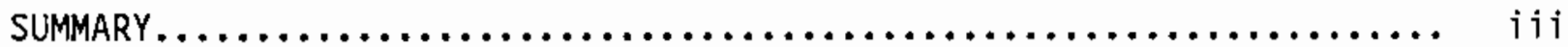

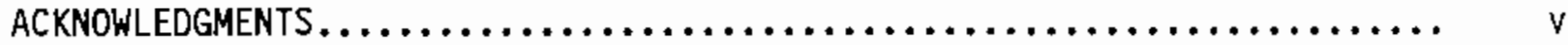

1.0 INTRODUCTION.................................... $1-1$

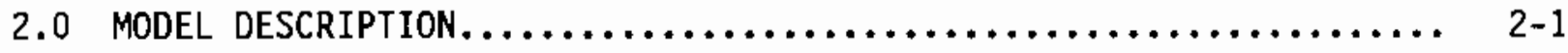

2.1 THE USE OF OPTIMIZATION IN THE MODEL............... $2-1$

2.2 SOFTWARE STRUCTURE, ......................... 2-3

3.0 USING THE MODEL............................... $3-1$

3.1 ASSEMBLING AN INPUT FILE...................... $3-1$

3.2 INITIATING A MODEL RUN........................ $3-9$

3.2 .1 Finding ITMAX......................... $3-9$

3.2 .2 Model Run of Test Case..................... 3-12

3.3 PROCESSING THE MODEL'S OUTPUT..................... 3-12

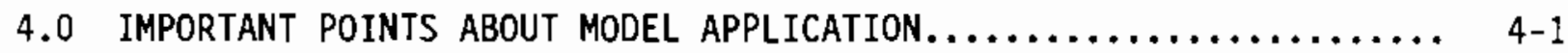

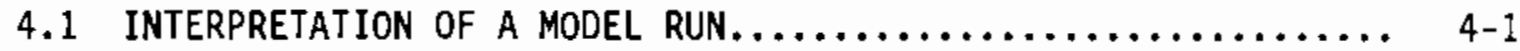

4.2 TERRAIN SETUP............................... 4-1

4.3 NUMERICAL STABILITY.......................... 4-2

4.4 PROPAGATION OF EDGE EFFECTS.................... 4 .4

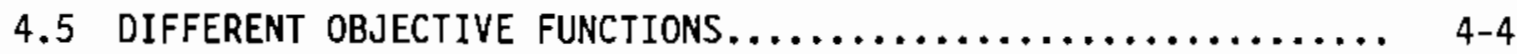

4.6 CHANGING THE ARRAY DIMENSIONS OF THE CODE AND SUPPLEMENTARY SOFTWARE................................. 4-5

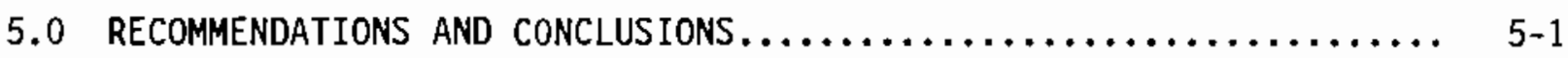

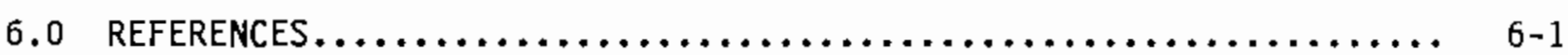

APPENDIX A: NOABL INPUT VARIABLES $\ldots \ldots \ldots \ldots \ldots \ldots \ldots \ldots \ldots \ldots \ldots \ldots \ldots$ A-1

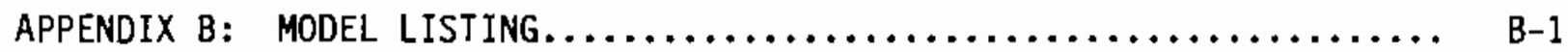

APPENDIX $c:$ TERRAIN DATA FOR MODEL TEST CASE................

APPENDIX D: LISTING OF THE OBJECTIVE FUNCTION AS A FUNCTION OF ITERATION NUMBER.......................... D-1

APPENDIX E: PRINTED OUTPUT FOR THE TEST CASE................ E-I

APPENDIX $F:$ SUPPLEMENTARY SOFTWARE..................... F-1

APPENDIX G: PRINTED OUTPUT FROM THE SUPPLEMENTARY SOFTWARE......... G-1 


\section{FIGURES}

2.1 Software Structure of the Mode1................ 2-5

3.1 Terrain Contours of the Test Case................ $3-2$

3.2 Sumnarized Description of Input File............... $3-3$

Input File for the Test Case................... $3-4$

3.4 Command Stream Required to Operate the Model........... 3-10

3.5 Objective Function as a Function of Iteration Number for

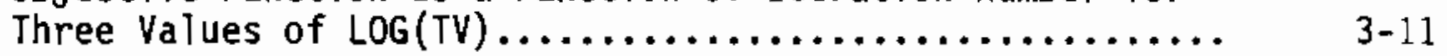

3.6 Sample Input to Supplementary Software that Produces Wind Speed contours (or wind Speed Ratios)................ 3-13

3.7 Wind Speed Contours, for the Test Case, Produced by the Supplementary Software and the Input File of Figure 3.6... 3-14

4.1 Number of Iterations, within the Subroutine "CNWAD", as a Function of the Overrelaxation Parameter.............. 4-3

4.2 Array Dimensions for the Model and Supplementary Software. $\quad 4-7$

\section{TABLE}

3.1 Coordinates and Wind Speeds of the Eight Tuning Sites.... 


\subsection{INTRODUCTION}

Over the past decade, the U.S. Wind Energy Program has sponsored the development and testing of several three-dimensional fluid flow models for wind energy applications. These models were, for the most part, developed to provide economical wind field predictors for wind resource assessments over large areas of complex terrain (Phillips 1979; Hiester and Pennell 1981). However, as the growth in wind farm development accelerated, a need arose for tools to predict flow variability over microscale $\left(\sim 10 \mathrm{~km}^{2}\right)$ areas in complex terrain. This report describes briefly the adaptation of an existing mass-consistent flow model to create such a tool and then explains the proper use of this tool for micrositing applications.

This report is intended to serve as a user's guide for the micrositing tool (which will be referred to as the 'model' in the remainder of this report). This model is based upon a combination of a mathematical optimization technique and the NOABL objective analysis model (Barnard et al. 1985). This user's guide should be used in conjunction with the NOABL objective analys is code user's guide (Phillips 1979). Phillips' report explains how the mass-consistent NOABL model simulates flow and describes the input parameters to the model.

It is recommended that users of this model have some background in the atmospheric sciences, particularly atmospheric stability and factors that affect flow in the boundary layer. Furthermore, users should have some knowledge of iterative methods for soiving systems of partial differential equations. Users of the model will need access to at least a minicomputer that has scientific computing power roughly equivalent to that of a VAX 11/780 and that has a resident FORTRAN compiler (preferably FORTRAN 77).

At this time the model should be considered as a research model and not as a fully refined micrositing tool. This is due to several reasons. The first of these is that the model has been verified using only a limited data set and although it performed well, further verification studies are necessary to establish its reliability under a variety of modeling situations. Second, 
the model is somewhat cumbersome to use, and it requires a significant amount of computer resources. Despite these difficulties, it is essential that the model be made available to the wind energy community so that experience gained by its use can guide further model development. 


\subsection{MODEL DESCRIPTION}

The NOABL flow model is the framework around which the current model was built. Since a NOABL user's guide has been published (Phillips 1979) and a mathematical description of the NOABL model is available in several publications (Traci et al. 1978; Heister and Pennell 1981), this section will briefly discuss the optimization procedure that has been integrated into the NOABL flow model. Further information about the optimization procedure and a description of the model verification studies are given by Barnard et al. (1985).

\subsection{THE USE OF OPTIMIZATION IN THE MODEL}

The NOABL model, without optimization, requires as input several parameters that describe the state of the atmosphere. Two of these parameters are of particular importance: the stability parameter, $\tau$, which is used to simulate the effect of atmospheric stability, and the mean wind direction, $\theta$, an estimate of the direction of the mean flow over the modeled area. Because a relationship between $\tau$ and any common measure of the atmospheric stability has not been discovered, it has not been possible to specify, as input to the model, a $\tau$ value that is appropriate for the wind flow conditions that are being simulated. Also, $\theta$ is often only approximately known because surface measurements of the wind direction, even if they are available, are influenced by the local terrain and do not represent the mean flow over the modeled area. This ignorance of appropriate $\tau$ and $\theta$ values is not a major problem, provided that the model-calculated winds are not very sensitive to these parameters. However, for many modeling situations, the calculated winds are quite sensitive to one or both of these parameters. Thus, without knowledge of appropriate values for them, confidence in the calculated wind fields is not justified.

The sensitivity of the calculated winds to $\tau$ and $\theta$ is a difficulty that can be turned to the modeler's advantage when a number of wind observations are available over the area to be modeled. In this case, the wind observations can be used to tune $\tau$ and $\theta$; this tuning process adjusts $\tau$ and $\theta$ so that the error between the observed winds and the model's simulation of these 
winds, is minimized. When this error is a minimum, $\tau$ and $\theta$ have taken 'optimum' values, and the calculated winds at the observation sites are as close as possible to the observations. Then it is presumed that the calculated winds away from the observation sites are also a good estimate of the actual winds. A past study (Barnard et al. 1985) has shown that this is the case, provided that the error is sufficiently small.

In the parlance of optimization, the error to be minimized is called the objective function. The objective function (OF) is quantitatively expressed by a ratio root mean square error, given by

$$
O F(\tau, \theta)=\left[\sum_{i=1}^{N}\left(r_{i}^{c}-r_{i}^{0}\right)^{2} / N\right]^{1 / 2}
$$

where $r_{i}^{o}$ are the observed wind-speed ratios at $N$ wind-observation sites, and $r_{i}^{c}$ are the model-calculated ratios for these same sites. For each set of modeled or observed speeds, the ratios are formed by dividing the speeds at the sites by the speed at a reference site; $i$ is chosen to be 1 for the reference site so that $r_{1}^{0}=r_{1}^{c}=1$. As indicated above, the $O F$ is a function of $\tau$ and $\theta$ because the calculated ratios depend upon these quantities.

An optimization procedure is merged with the NOABL model to minimize the objective function. In practice, two identical optimization routines similar to the Coggins algorithm (Kuester and Mize 1973) act on $\tau$ and $\theta$ until the objective function is minimized. Oerivative-based optimization schemes, such as steepest descent, were avoided because of the extreme computational effort required to calculate objective function derivatives accurate enough to be useful in these schemes. 


\subsection{SOFTWARE STRUCTURE}

The software structure of the model is depicted in Figure 2.1 using code-like structured English. This figure provides a basis for the following discussion of the optimization procedure employed in the model.

As shown in the figure, the model is configured to optimize up to two parameters per model run. The two input parameters, which are optimized, are

1. Stability parameter (TV)

2. Initial wind field direction (WDR).

(TV and WDR are the model variables that correspond to $\tau$ and $\theta$, respectively.)

To run the model requires wind speed observations at several locations and preferably one observed wind direction within an area of interest. If a direction observation is not avallable, an estimate of the mean wind direction is adequate. The minimal data requirements as a function of grid size and terrain complexity have yet to be determined; however, good results have been obtained when as few as six simultaneous wind speed measurements were made within a $4 \mathrm{~km}^{2}$ area of complex terrain (Barnard et al. 1985).

The model, in the form listed in Appendix $B$, is configured to optimize first on the variable WDR (using subroutine NEWMIN), and then inside of this optimization, the optimal stability parameter (TV) is calculated (by subroutine STABRMIN). A typical model run might, for example, do the following:

STEP 1 NEWMIN starts optimizing on wind direction by initializing the wind field at the user-specified wind direction; it then passes control to an "inner loop" (by invoking function OF1, which in turn calls STABRMIN)

STEP 2 STABRMIN, in the inner loop, optimizes on TV by invoking function of to calculate the objective function as a function of the wind direction and the initial TV

STEP 3 function OF causes the SOR algorithm in subroutine CNWAO to run for a user-specified ${ }^{(d)}$ number of iterations, removing most of

(a) Determination of the proper number of iterations depends upon the number of iterations required for the objective function to converge within the SOR algorithm; methods of estimating the appropriate number of iterations are discussed in Section 3.2.1. 
the divergence from the flow, then OF calculates the objective function from the resultant wind field

STEP 4 STABRMIN then increments TV and step 3 is repeated until the optimal TV is obtained for the initial wind direction

STEP 5 control passes from STABRMIN, through OF1, and then back to NEWMIN where the initial wind direction is incremented; at this point the flow of control passes back to step 1 and OF 1 is invoked.

The above steps are repeated until the optimal initial wind direction for the model run is calculated. Note that at each step in the outermost loop (in this case the wind direction optimization) the model completely optimizes on TV. This means that several executions of the SOR algorithm (CNWAD) are required to calculate the optimal TV for one value of WDR, and numerous executions of CNWAD are required to complete one mode1 run that optimally calculates two NOABL input parameters (WDR and TV). The methods of reducing the CNWAD executions are discussed in Sections 3.1 and 3.1.2. (It is not necessary to optimize on both WDR and TV. If desired, the model can be directed to optimize on one or the other of these variables.)

Once optimal model parameters have been calculated, the model saves the calculated flow field and all parameters. Special software, which is described later in this report, can process the calculated flow field to produce graphical displays of the wind field. 


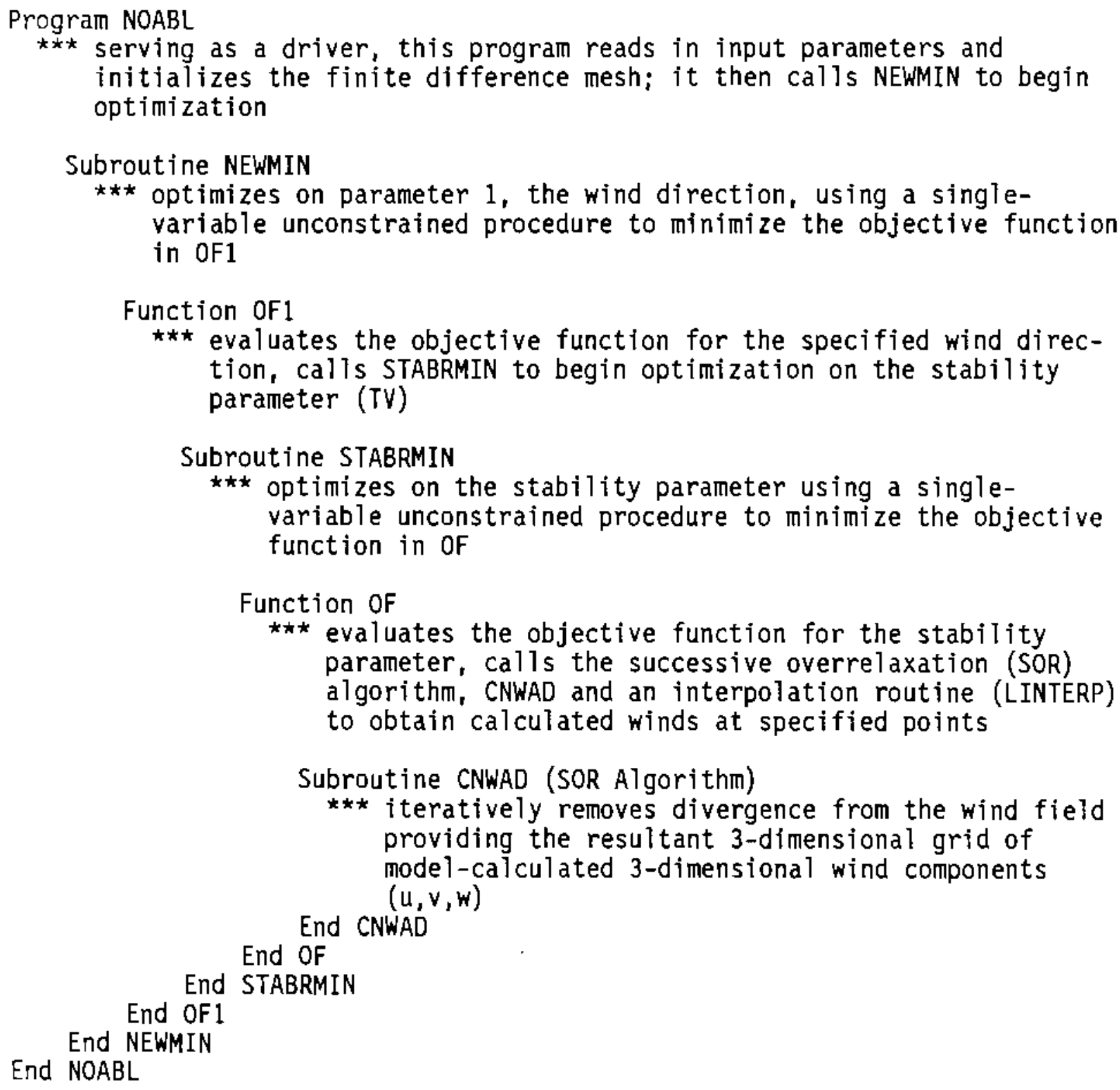




\subsection{USING THE MODEL}

This section describes the steps necessary to assemble an input file, start a model run, and then process the model's output. Some familiarity with the NOABL user's guide (Phillips 1979) is necessary to understand the material presented here.

The application of the model will be illustrated by a test case. This case represents an actual flow simulation over a wind farm in the Altamont Pass area of California. Figure 3.1 shows the terrain of the test case. The black dots in this figure mark the locations of eight wind observation stations used for model tuning. The positions of these stations and of the gridded terrain elevations used to generate this figure are referenced from the origin of the modeling grid. This is located at the lower left-hand corner of this figure, at the point $x=0, y=0$.

\subsection{ASSEMBLING AN INPUT FILE}

The model requires as input: (1) parameters that specify the geometry of the finite-difference mesh; (2) gridded terrain elevations over the area to be modeled; (3) wind speed observations and the location of these observation sites; (4) initial guesses of $\tau$ and $\theta_{;}$and (5) parameters that control the operation of the optimization and the overrelaxation process.

The model is comprised of parts of the NOABL code, which have been merged with an optimization scheme, and the dual nature of the model is reflected in the input file. One part of this file feeds the optimization software. The other part supplies input to a modified NOABL code, and these variables are put in exactly the same format as if they were to be used with the original NOABL model (i.e., an asterisk in column 1, followed by the variable name, its location in blank common, and finally, the value of the variable). Figure 3.2 is a summarized description of a typical input file, and Figure 3.3 shows the input file for the test case. Lines 2 through 21 contain the NOABLrelated variables; the other lines are data associated with the optimization. (Note: Some of the variables are used by both the NOABL code and the 
CONTOUR INTERVAL - $10 \mathrm{M}$

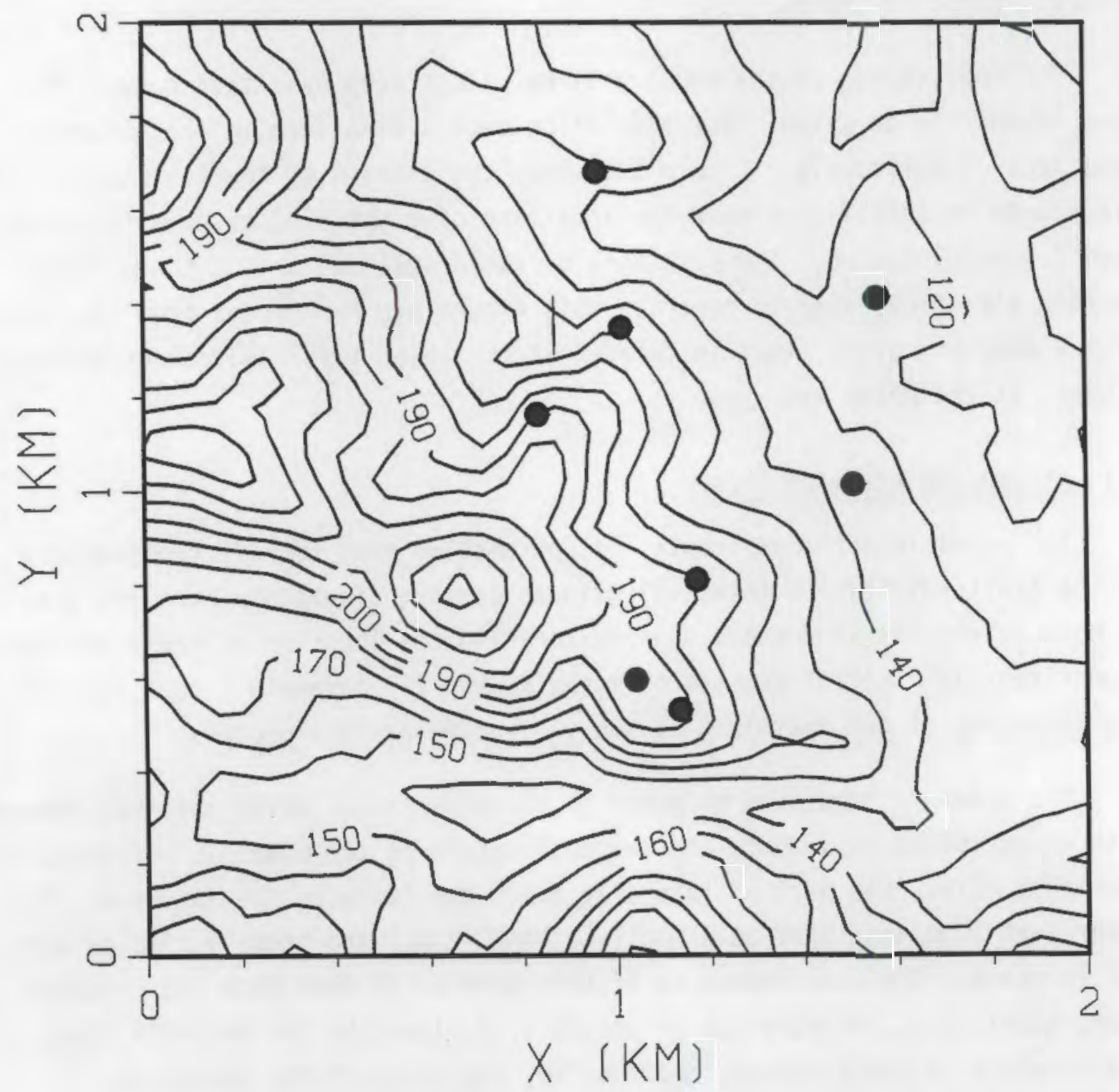

FIGURE 3.1. Terrain Contours of the Test Case. The contour interval is 10 meters. The black dots mark the locations of the 8 tuning sites. 
1 TITLE (up to 70 characters)

2 *DX (grid point spacing (meters) - $x$ direction)

3 *DY (grid point spacing (meters) - y direction)

4 *IMAX (number of grid points in the $x$ direction)

5 *JMAX (number of grid points in the $y$ direction)

6 *DZMIN (height (meters) of lowest conformal layer)

7 *KMAX (number of grid points in the $z$ direction or number of conformal levels)

8 *ZDIST (distance (meters) from the origin to the top of the grid)

9 *XSTA ( $x$ coordinates (meters) of tuning stations)

10 «YSTA (y coordinates (meters) of tuning stations)

11 *NSTAT (number of tuning stations)

12 *XO ( $x$ coordinate (meters) of reference site)

13 *YO (y coordinate (meters) of reference site)

14 *ZO (anemometer height of reference site (meters AGL))

15 *WSPD (wind speed (meters/sec) at reference site)

16 *WDR (wind direction (degrees) at reference site)

17 *NPTS (number of reference sites - always 1)

18 "ITMAX (maximum number of iterations allowed in subroutine "CNWAD")

19 *ITERAN (always 1, directs the program to read terrain data from LU 8)

20 "ITYLOR (always 1 , directs the program to invoke the routine "TAYLOR")

21 *END OF DATA \$ (informs input subroutine that there is no more NOABL input)

22 (wind speeds (meters/sec) at the tuning sites)

23 (anemometer heights (meters AGL) of the tuning sites)

24 (initial guesses of wind direction and stability)

25 (direction and stability switches, $1=$ optimize, $0=$ don't optimize)

26 (direction and stability optimization step sizes)

27 (direction and stability optimization convergence criteria)

28 (find objective function as a function of iteration ? $1=y e s, 0=n 0$ )

FIGURE 3.2. Summarized Description of Input File 
1 TEST CASE OF NOABL WITH OPTIMIZATION ON 8 DATA LOCATIONS

$2 \approx D X \$ 6,50.0$

$3 *$ DY $\$ 7,50.0$

4 *IMAX $\$ 14,40$

$5 * J \operatorname{MAX} \$ 24,40$

6 *DZMIN $\$ 9,20$.

7 *KMAX $\$ 27,10$

8 *ZDIST $\$ 38,700$.

9 \#XSTA $\$ 292,1041.0,1135.73,1172.33,834.03,1013.83,1507.63,962.03,1562.43$

10 *YSTA $\$ 317,598.0,533.64,811.04,1164.54,1350.54,1015.24,1682.74,1417.54$

$11 *$ NSTAT $\$ 291,8$

$12 * \times 0 \$ 141,1041.0$

$13 \approx Y 0 \$ 191,598.0$

$14 \star Z 0 \$ 241,14.02$

15 *WSPD $\$ 91,18.3$

16 *WDR $\$ 41,240.0$

17 *NPTS $\$ 33,1$

18 *ITMAX $\$ 40,25$

19 *ITERAN $\$ 19,1$

20 *ITYLOR $\$ 20,1$

21 *END OF DATA \$

$2218.3,17.4,13.4,13.4,11.6,11.6,12.5,12.1$

$2314.02,14.02,14.02,14.02,14.02,14.02,14.02,14.02$

$24240.0,1.0$

251,1

$26 \quad 5.0,0.2$

$27 \quad 0.5,0.05$

280

FIGURE 3.3. Input File for the Test case 
optimization.) The NOABL-related section of the input file is not orderspecific, and the variables can be shifted around without affecting the input process. Also, more variables may be added to this section, if necessary. Phillips' (1979) description of the NOABL-related input variables and the default values that they assume, if they are not explicitly included in the input file, comprises Appendix A of this report.

Each line of the input file contains a single input variable or array of related variables. A line-by-line description of the summarized input file follows, along with a parallel description of the specific test-case values that have been assigned to the input variables. Files for other runs may contain a different number of lines, depending upon the number of variables placed in the NOABL section.

Line 1 is a title, up to 70 characters long.

Lines 2 and 3 contain DX and DY, which are distances (in meters) between the horizontal grid points in the $x$ and $y$ directions, respectively. If $h$ is the array that contains the terrain elevations, the elevation $h(i, j)$ has $x$ and $y$ coordinates of $x=D X / 2+(i-1) * D X$ and $y=D Y / 2+(j-1) * D Y$. With this definition of the terrain elevation locations, it is important to realize that $h(1,1)$ is the elevation at the position $x=D X / 2 m, y=D Y / 2 m ; h(1,1)$ is not located at the origin. For the test-case terrain depicted in Figure 3.1, DX and $\mathrm{DY}$ are both 50 meters.

Lines 4 and 5 contain the number of grid points in the $x$ and $y$ directions, which are given by the model variables IMAX and JMAX, respectively. For the test-case IMAX $=\operatorname{JMAX}=40$, so that the modeled area is a $2 \mathrm{~km} \times 2 \mathrm{~km}$ square, over which there are 1600 terrain elevations. The terrain file is listed in Appendix $C$, and construction of this file is explained in the NOABL user's guide (Phillips 1979).

Vertical zoning in the model is controlled by the variables on lines 6 , 7, and 8. DZMIN is the thickness of the lowest conformal level, KMAX, the number of vertical conformal levels, and ZDIST, the distance from the origin to the top of the modeling domain. These variables are assigned values 20 meters, 10, and 700 meters, respectively, for the test simulation. Further 
description of these variables and an explanation of the terrain conformal coordinate system are found in the NOABL user's guide (Phillips 1979).

The model in its present form can accommodate up to 40 grid points in each horizontal direction and up to 10 points in the vertical. Therefore, IMAX and JMAX cannot exceed 40, and KMAX cannot exceed 10. However, the array dimensions of the model can be changed to allow more grid points; this procedure is described in Section 4.6.

Table 3.1 lists the $x$ and $y$ coordinates (in meters) of the 8 observation stations and hourly averaged wind speeds $(\mathrm{m} / \mathrm{s})$ for each of the 8 stations. These are the test-case wind speeds that the model uses during the tuning process to find the optimum values of $\tau$ and $\theta$. The first station in this list is the reference site, and observed ratios are obtained by dividing the speeds listed in Table 3.1 by the reference site speed. These ratios are used as the observed ratios in Equation (1). The reference site is usually taken to be the observation site with the highest wind speed. The station coordinates are placed in the array variables XSTA (line 9) and YSTA (line 10); NSTAT (line 11) is assigned the total number of tuning stations; for the testcase this is 8 . The first entry into both XSTA and YSTA must be the reference site coordinates. These same two coordinates are repeated in lines 12 and 13 , which contain the variables $X 0, Y 0$. These are the horizontal coordinates of the reference site $(X O=1041 \mathrm{~m}, Y O=598 \mathrm{~m})$, and $Z 0$ (line 14) is the reference site anemometer height (14.01 m AGL). WSPD (1ine 15) and WDR (1ine 16) are the wind speed and direction at the reference site, which are $18.3 \mathrm{~m} / \mathrm{s}$ and $240^{\circ}$, respectively. (If a wind direction measurement is not available at the reference site, an estimate of the direction will suffice.) NPTS on line 17 is set equal to 1 . This informs this model that only one wind observation, the reference site, is to be used to build the initial guess of the wind field. For the present model configuration, NPTS should always be 1 , and only one entry should be made on lines 15 and 16 . 
TABLE 3.1. Coordinates (m) and Wind Speeds $(\mathrm{m} / \mathrm{s}$ ) of the Eight Tuning Sites. $x$ and $y$ are measured from the model's origin; $h$ is the anemometer in meters AGL.

\begin{tabular}{cccc}
$\mathrm{x}(\mathrm{m})$ & $y(\mathrm{~m})$ & $\underline{\mathrm{h}(\mathrm{m})}$ & $\begin{array}{c}\text { Wind Speed } \\
(\mathrm{m} / \mathrm{s})\end{array}$ \\
\hline 1041.0 & 598.0 & 14.02 & 18.3 \\
1135.73 & 533.64 & 14.02 & 17.4 \\
1172.33 & 811.04 & 14.02 & 13.4 \\
834.03 & 1164.54 & 14.02 & 13.4 \\
1013.83 & 1350.54 & 14.02 & 11.6 \\
1507.63 & 1015.24 & 14.02 & 11.6 \\
962.03 & 1682.74 & 14.02 & 12.5 \\
1562.43 & 1417.54 & 14.02 & 12.1
\end{tabular}

ITMAX (on line 18) controls the maximum number of iterations within the subroutine CNWAD. The number of iterations that take place in one call to subrouting CNWAD is ITMAX + 1. - This subroutine removes the divergence from the wind field, and the final mass-consistent wind field that results from this procedure is used to find the calculated ratios, which, in turn, are used to evaluate the objective function during one iteration of the optimization process. If ITMAX is too small, then inaccurate values of the objective function will be fed to the optimization routine; if ITMAX is too large, the CPU time required to evaluate the objective function will be unnecessarily large. Methods of estimating an acceptable value of ITMAX will be discussed in Section 3.2.1. For the test case, ITMAX was set to 25 iterations.

On line 19, the variable ITERAN must have a value of one. This directs the model to read the terrain data from a file that is assigned to logical unit 8.

Line 20 is the input for the variable ITYLOR, which is always set to 1 causing the subroutine TAYLOR to be invoked. This subroutine is used to find model-derived vertical wind speed profiles over the observation sites. From these profiles, model-calculated winds at the anemometer heights are determined; the ratios formed from these are used to evaluate the objective function. The model is informed that all the NOABL-related variables have been read by the "*END OF NOABL DATA \$" on line 21. 
The optimization software receives data from the next 6 lines. Line 22 contains the set of wind speeds (in $\mathrm{m} / \mathrm{s}$ ) used for model tuning. The speeds must be given in the same order as the station coordinates in the arrays XSTA and YSTA, and the number of speeds must equal NSTAT. The anemometer heights of the tuning sites are given in 1 ine 23 , and these must be given in the same order as the station coordinates.

Line 24 contains the initial guesses of the mean flow direction, $\theta$, and the stability parameter, $\tau$. If a direction measurement is available within or near the modeled area, this direction can be used as the initial guess for $\theta$; otherwise, a crude estimate of $\theta$ is adequate. The value assigned to $\theta$ should be the same as the value given to WDR on line 16. A reasonable initial guess for $\tau$ is 1 .

Switches that control the optimization are on line 25 . These switches have either a value of 1 (on) or 0 (off); the first switch is for $\theta$ and the second is for $\tau$. If the switch is set equal to 1 , then the variable in question is optimized. If both switches are zero, the model operates without optimization.

Line 26 contains the optimization step sizes for $\theta$ and $\tau$. For this case, $\theta$ is initially incremented by $5^{\circ}$ during each optimization step; $\tau$ is incremented by $10^{\circ}$. (The actual step size for $\tau$ is $10^{x}$, where $x$ is the second value in line 26.$)$

Line 27 contains the convergence criteria for the optimization of $\theta$ and $\tau$. When $\theta$ changes less than $.5^{\circ}$ between steps, and $\log _{10}(\tau)$ changes less than 0.05 , the optimization is considered to have converged, and the routine stops. In general, the values on 1 ines 26 and 27 can remain unchanged from run to run.

Finally, line 28 is a switch that has values of either 1 (on) or 0 (off). When this switch is equal to 1 , the code will find the objective function as a function of the number of iterations within the CNWAD routine. This information is used to estimate ITMAX. When the switch is off, a normal optimization run occurs, using the value of ITMAX determined previously. 


\subsection{INITIATING A MODEL RUN}

Several steps are involved in starting a model run. Most of these steps are very simple and are concerned with connecting the input and output to the appropriate files. However, before starting a model run that finds optimum values for $\tau$ and $\theta$, it is necessary to have an estimate for ITMAX. This requires operation of the model in a special, non-optimizing mode. (This mode is invoked by setting the switch, on line 28 of the input file, equal to 1.)

The files associated with the model's use are the input file, which was described in Section 3.1, a terrain input file, which contains the gridded terrain data, and two output files. One output file is an ASCII file that logs the events that occur during the operation of the model. The other output file is a binary file that has as its contents the common block COMON and the final, computed wind components. The common block COMON stores the model variables and the terrain elevations. The binary file is not created if the model is being operated to find ITMAX. In that case, a special ASCII file is opened that receives information from which ITMAX can be determined.

Only a few job-control statements are needed to run the model. Figure 3.4 displays the command sequence that is used on a VAX/VMS operating system. Although this sequence is specific to the VAX/VMS operating system, the assignments of logical units to the input and output files are easily understood. Therefore, conversion of these commands to another system should pose little difficulty.

\subsubsection{Finding ITMAX}

A great deal of CPU time is sometimes required to operate the model. Therefore it is desirable to keep the total number of iterations per run as low as possible. One way of achieving this is to minimize the number of iterations in the subroutine CNWAD, which calculates, using an iterative overrelaxation technique, the nondivergent wind field. This routine stops when either a given number of iterations has occurred (specified by the variable ITMAX), or a given convergence criterion is met (specified by the variable EPSLN). The objective function is calculated from the nondivergent wind field, and if 
\$ ! ASSIGN THE TERRAIN FILE TO LOGICAL UNIT 8

\$ ASSIGN TERRAIN.DAT FORO08

\$! ASSIGN THE BINARY OUTPUT FILE TO LOGICAL UNIT 10

\$! (THIS ASSIGNMENT IS NOT NECESSARY IF FINDING THE OBJECTIVE FUNCTION

$\$$ ! AS A FUNCTION OF ITERATION)

$\$$ ASSIGN OUTPUT.BIN FOR010

\$! ASSIGN THE ASCII DUTPUT TO LOGICAL UNIT 6

$\$$ ASSIGN OUTPUT.DAT FORO06

$\$$ ! ASSIGN THE INPUT FILE TO LOGICAL UNIT 5

$\$$ ASSIGN INPUT.DAT FORO05

\$! RUN THE MODEL ("MODEL" IS THE EXECUTABLE CODE)

$\$$ RUN MODEL

\$! (THE ASSIGNMENT BELOW IS ONLY NECESSARY IF FINDING THE OBJECTIVE

$\$$ ! FUNCTION AS A FUNCTION OF ITERATION)

$\$$ ! ASCII FILE THAT CONTAINS THE OBJECTIVE FUNCTION AS A FUNCTION OF

\$! ITERATION IS ASSIGNED TO LOGICAL. UNIT 17

$\$$ ASSIGN FILE.DAT FORO17

FIGURE 3.4. Command Stream Required to Operate the Model. This set of commands is appropriate for a VAX/VMS operating system. The statements that are preceded by a '!' are comments.

most of the divergence has not been removed from the field by the routine CNWAD, then erroneous values of the objective function will occur, and the optimization may produce results that are misleading.

One way of gauging the accuracy of the objective function is to observe its behavior as the iteration proceeds. This behavior is shown in Figure 3.5, which plots the objective function against iteration number for three different values of $\log _{10}$ (TV). (The test case terrain and model parameters were used to make this graph.) For all three values of $\log _{10}$ (TV), the objective function does not reach a steady state until about the 25th iteration. Further iterations past this point do not greatly. alter the value of the objective function; therefore, the overrelaxation may stop at this point and, for this 
case, ITMAX can be taken to be 25 . Usually it is only necessary to find ITMAX for one value of TV, for a given modeled area.

The data used to create Figure 3.5, the value of the objective function at each iteration in CNWAD, are calculated by a special model run. To invoke this run, the switch on line 26 of the input file is set to 1 , instead of 0 . The iteration number and objective function are printed on a special ASCII file, which is assigned to logical unit 17. (Because of this, a command must be included in the command sequence that assigns a file to LU17.) For the test case data and a value of TV equal to 1 , this special ASCII file is shown in Appendix $D$.

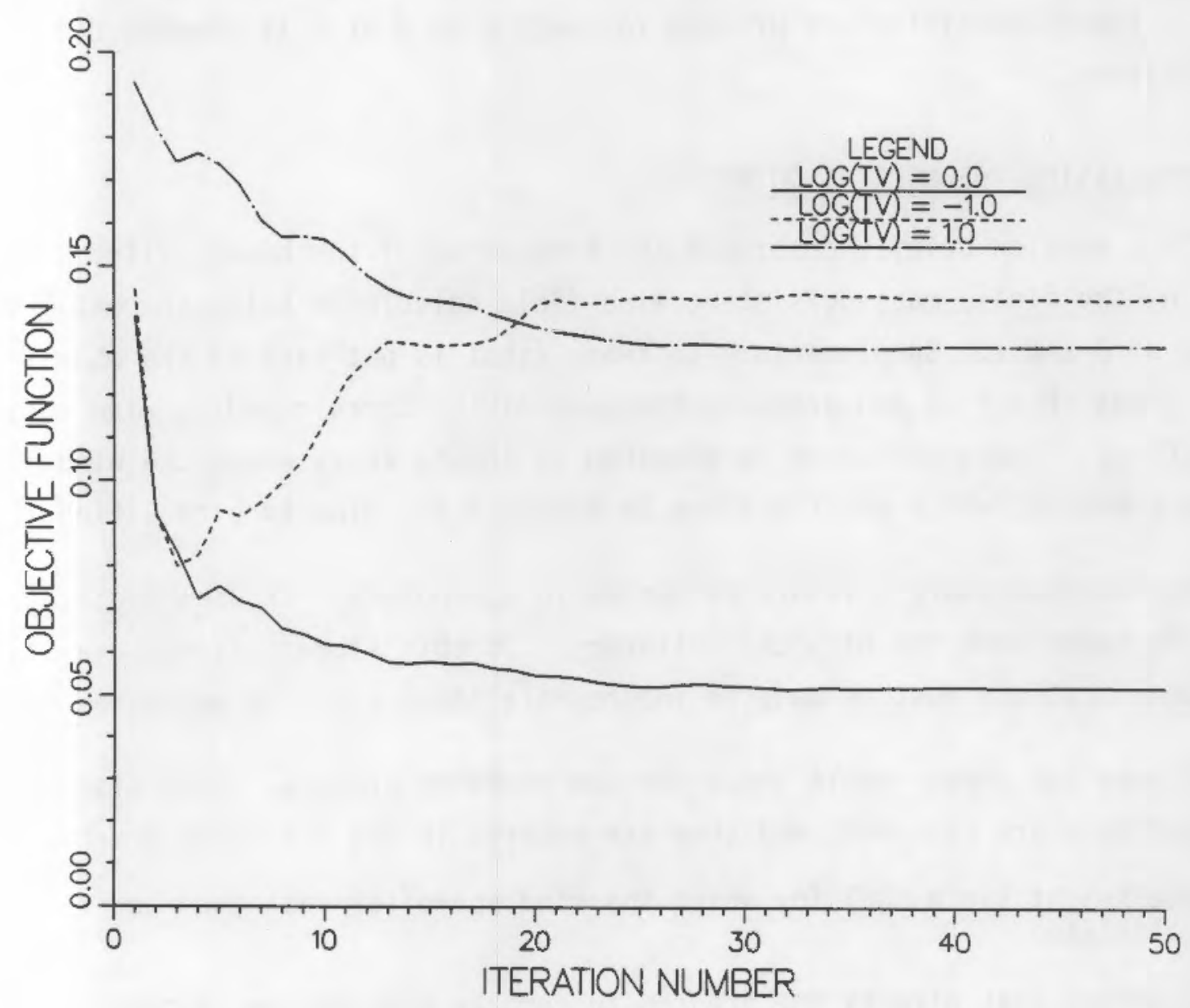

FIGURE 3.5. Objective Function as a Function of Iteration Number for Three Values of LOG(TV). The test case terrain and model parameters were used in developing this graph. 


\subsubsection{Model Run of Test Case}

The file shown in Figure 3.2 was used as the input file for a model run. The printed output is displayed in Appendix E. At the end of this output, the optimum values for $\tau$ (TV) and $\theta$ (WDR) are given, and also the minimum value of the objective function. These values are $0.57296,238.82$, and 0.03393 , respectively. The total number of iterations in the subroutine CNWAD was 624, which represent 25 calls to the subroutine CNWAD. The VAX 11/780 CPU time for this run was about 1 hour.

The bulk of the printed output consists of the calculated and observed ratios, and the calculated and observed speeds, at each of the NSTAT tuning sites. These quantities are printed for each time $\theta$ or $\tau$ is changed during the optimization.

\subsection{PROCESSING THE MODEL'S OUTPUT}

This section briefly describes the processing of the binary file, which contains the final, mass-consistent wind field calculated using the optimum values of $\theta$ and $\tau$. Supplementary software (that is not part of the model code) takes this file and produces contours of the terrain and/or wind speeds (or ratios). These plots can be examined to locate areas where the wind speeds may be enhanced, which may therefore be suitable for wind turbine siting.

The supplementary software is listed in Appendix F. It uses plotting commands taken from the DISSPLA (a) library. If this library is not available, then modifications must be made to incorporate other plotting software.

Figure 3.6 shows sample input for the plotting program. Only five pieces of input data are required, and they are entered in the following order:

1) the height (in $m A G L$ ) for which the wind speed (or ratio) contours are calculated

2) a switch that directs the program to compute wind ratios instead of wind speeds $(Y=$ calculate ratios, $N=$ calculate wind speeds only)

(a) DISSPLA is a proprietary software product of Integrated Software Systems Corporation. 
14.02 (HEIGHT (M AGL) AT WHICH THE WIND FIELD WILL BE CALCULATED)

$N$ (CALCULATE RATIOS? $N=N O, Y=Y E S$ )

2.0 (WIND SPEED CONTOUR INTERVAL (M/S), OR RATIO CONTOUR INTERVAL)

10.0 (TERRAIN CONTOUR INTERVAL (M))

OUTPUT.BIN (NAME OF THE BINARY OUTPUT FILE)

FIGURE 3.6. Sample Input to Supplementary Software that Produces Wind Speed Contours (or Wind Speed Ratios). The parentheses enclose comments that describe the input.

3) the wind speed (or ratio) contour interval (in $\mathrm{m} / \mathrm{s}$ if speed contours are calculated)

4) the terrain contour interval (meters)

5) the name of the NOABL binary file.

If item 3 (or 4 ) is assigned negative value, then the speed contours (or the terrain contours) are not calculated.

The graphical output of the plotting program using directives of Figure 3.6, is shown in Figure 3.7. This figure depicts the terrain contours as dotted lines at $10 \mathrm{~m}$ intervals, and the wind speeds are contoured at $2 \mathrm{~m} / \mathrm{s}$ intervals. Appendix $G$ is a listing of the printed output. This printed output includes the calculated and observed ratios at the tuning sites, and the calculated wind speeds at the specified height. The horizontal positions of the calculated wind speeds correspond to the horizontal positions of the terrain elevations. Therefore, the speed $S(i, j)$ is located at $x$ and $y$ positions of $D X / 2+(i-1) * D X, D Y / 2+(j-1) * D Y$, respectively, where these positions are measured relative to the origin. 
CONTOUR INTERVAL - $10 \mathrm{M} \quad$ AGL $-14.02 \mathrm{M}$

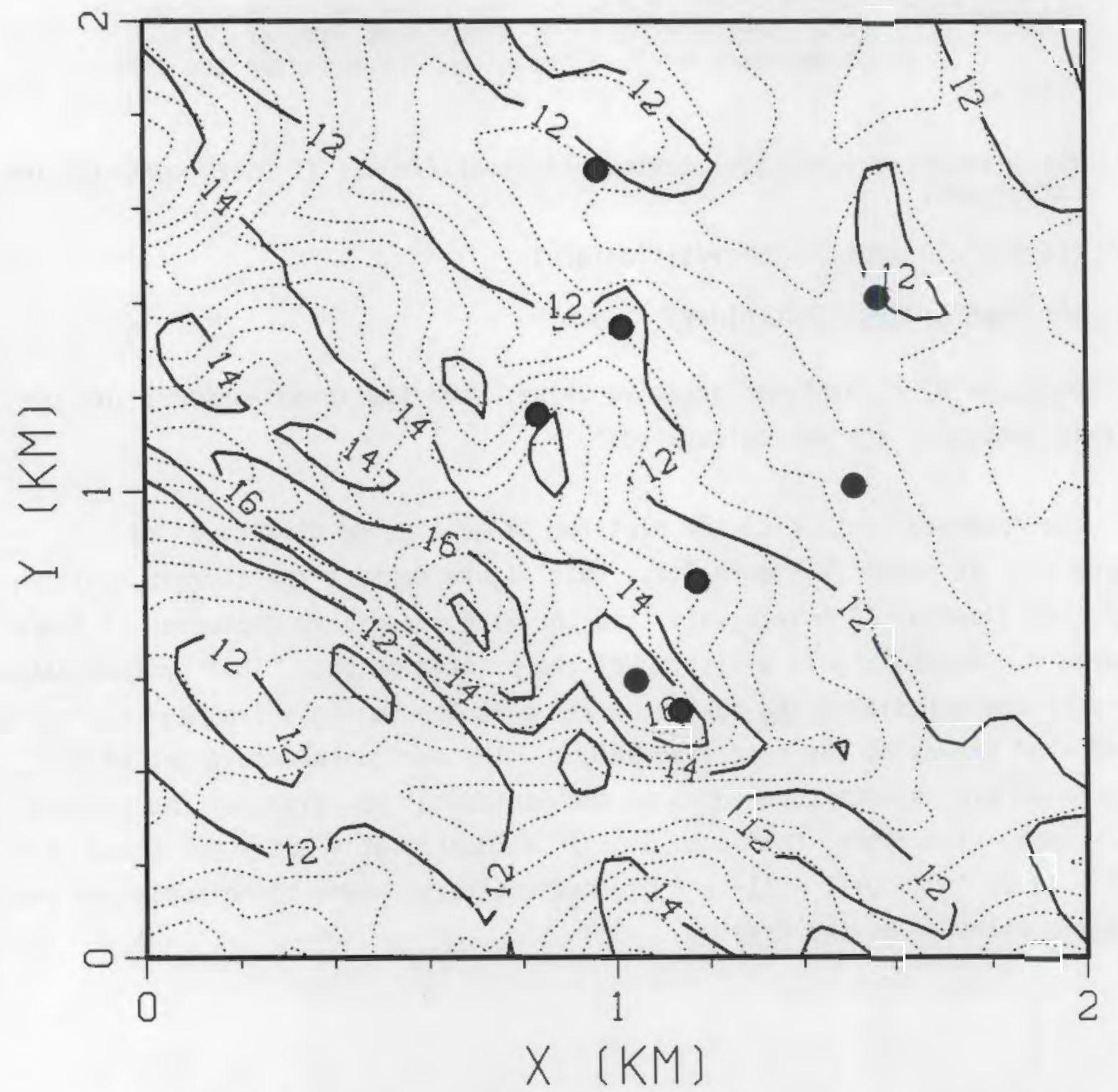

FIGURE 3.7. Wind Speed Contours, for the Test Case, Produced by the Supplementary Software and the Input File of Figure 3.6. 


\subsection{IMPORTANT POINTS ABOUT MODEL APPLICATION}

This section discusses several problems that the user might encounter when running the model and interpreting the model output. Methods of avoiding or ameliorating these problems are provided for the user.

\subsection{INTERPRETATION OF A MODEL RUN}

This model is a diagnostic model that calculates a steady-state flow over the area of concern. To properly interpret the results of a model run, the user must know what, in the real world, equates most closely to 'steady-state' flow. The authors have examined analyses of various time averages of wind speed and direction at the Goodnoe Hills MDD-2 test site near Goldendale, Washington. The basic data collection rate for the period of study was 5 seconds. Running means were calculated for the wind data for averaging intervals of 2 minutes, 10 minutes, and 30 minutes. An examination of these means indicated that steady-state flow was usually observed for averaging times greater than 10 minutes.

It is reasonable to assume that a model run represents a 10 - to 60 -minute picture of the mean flow. To apply the modeled wind flow for micrositing, it is desirable to simulate the flow for an ensemble of cases that represent all the primary power-producing wind regimes for the area of interest. In this manner, the wind energy potential of a wind farm can be evaluated with the flow model, by running the model using optimally calculated input parameters for each of the important wind regimes.

\subsection{TERRAIN SETUP}

Evenly spaced gridded terrain elevations over an area of interest are required to run the model. The importance of having high quality terrain data cannot be overemphasized. To determine the resolution of the terrain grid, users should consider the size of the terrain features that influence the wind flow in the area of interest. To ensure the quality of the terrain data and accuracy of the model results, users should carefully edit the data to remove any erroneous terrain elevations. The terrain grid should not be 
so coarse that such features become smoothed out. For the moderately complex terrain in the Altamont Pass area of California, it was found that the minimal grid distance above which significant loss of terrain resolution occurred was 50 meters. This can be used as a rough guideline for other areas of complex terrain until experience is gained using the model in the area of interest.

As noted by Phillips (1979), the grid cell aspect ratio (DX/DY) affects the convergence rate of the iterative scheme used to solve the system of equations in the model. The user should use a square mesh to minimize model run time. That is, DX and DY should be equal.

Terrain data is entered into the model from left to right, beginning at the lower left corner of the grid (the originn) and working upward, row by row, toward the top row. The units used for terrain by the model are heights above sea level in meters.

\subsection{NUMERICAL STABILITY}

The numerical method used to remove the divergence from the flow field is block overrelaxation. Occasionally this method becomes unstable and does not converge. This problem is most often associated with simulations of a stable atmosphere (i.e., $\log _{10}(T V)<0.0$ ). However, terrain slope can also contribute to nonconvergence. As the terrain slope increases, the amount of adjustment required to make the wind field mass-consistent increases. If the slope becomes too great, the numerical technique can exhibit numerical instability.

One important parameter of the overrelaxation procedure is the overrelaxation parameter, w. Figure 4.1 shows the number of iterations required for convergence as a function of $\omega$ for three different grid sizes imposed on the same terrain (not the same terrain as used in the test case). For a given grid size, one value of $w$, called the optimum overrelaxation parameter, wopt ' is associated with the minimum number of iterations. As indicated in Figure 4.1, values of $w$ much greater than $w_{\text {opt }}$ cause a rapid rise in the number of iterations required for convergence and may lead to nonconvergence. For values of w less than wopt' convergence usually occurs, although at a slower rate. 


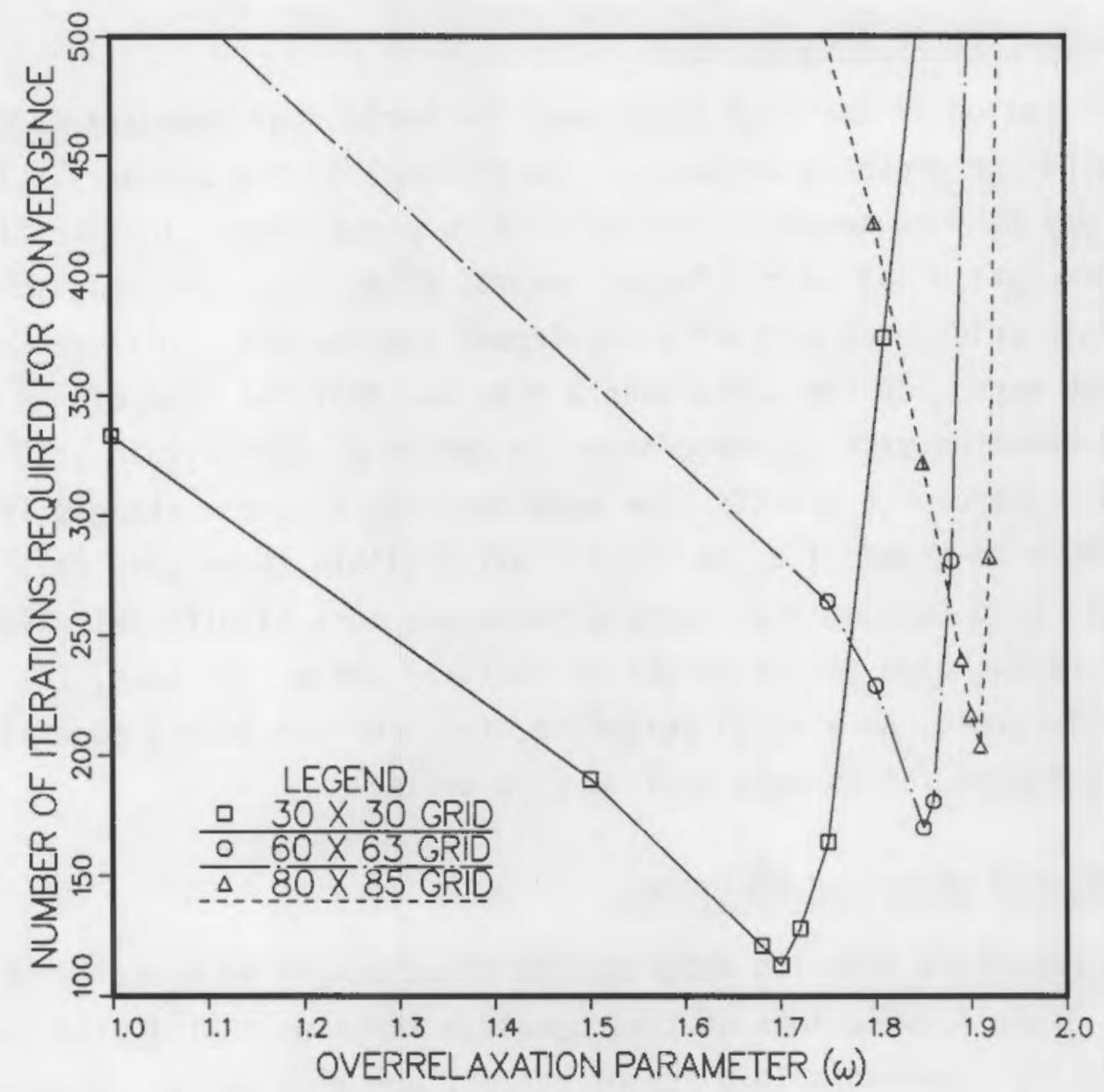

FIGURE 4.1. Number of Iterations, Within the Subroutine "CNWAD", as a Function of the Overrelaxation Parameter

If $\omega$ is not explicitly specified in the input file, it is calculated by the model. Occasionally the model-calculated $\omega$ value is too large and the model fails to converge. If this occurs, the user can decrease the magnitude of $w$, and often this reduction is sufficient to prevent numerical instability. If desired, the value of wopt may be determined by numerical experimentation. That is, the number of iterations for different values of $w$ can be noted and from this information, one can estimate wopt.

To specify a value for $w$, a new line must be added to the input file before the *END OF NOABL DATA $\$$ and after the title (the first line). The format of this line is "*OMEG $\$ 34, x "$ where $x$ is the value of $w$. 


\subsection{PROPAGATION OF EDGE EFFECTS}

Calculation of the wind speed near the horizontal boundary of the modeling grid may not be accurate because of the presence of the boundary. This 'edge effect' may be felt several grid cells in from the edge. To investigate the inward propagation of edge effects, several NOABL runs were made such that the terrain grids used partially overlapped one another. Differences in the calculated winds for the cases when a site was near the edge of the terrain grid and when the site was more near the center of the terrain grid were examined. These edge effects have been observed to cause changes in the calculated wind speed of up to $30 \%$ for sites within three grid cells of the horizontal grid boundaries. These effects are most significant when terrain features having high relief (peaks or valleys) are on, or near, the edge of the terrain grid. As a rough guideline, the user can expect edge effects to propagate inward for as many as five grid cells.

\subsection{DIFFERENT OBJECTIVE FUNCTIONS}

The objective function expressed in Equation (1) is based on wind speed ratios. Other formulations of the objective function, using wind speeds or wind velocity components in place of ratios, are also valid. However, when using speeds or velocity components, the quantities must be multiplied by a linear scale factor, $f$. (This scaling is necessary to counteract a tendency of the model to calculate wind speeds that are either too high or too low.) With a ratio-based objective function, implicit scaling is performed using a scale factor that is the reciprocal of the wind speed at the reference site. For other situations, $f$ must be explicitly found during the calculation of the objective function.

Determination of $f$ is quite simple. When $f$ is included as part of the objective function, the expression for this quantity becomes

$$
O F=\left[\sum_{i=1}^{N}\left(f s_{i}^{c}-s_{i}^{0}\right)^{2} / N\right]^{1 / 2} .
$$


Once the speeds $s_{j}^{c}$ are calculated, $f$ is found so that the objective function assumes a minimum value. This is easily done by taking the derivative of the objective function with respect to $f$, setting the derivative equal to zero, and then solving for $f$. The expression for $f$ is then

$$
f=\sum_{i=1}^{N} s_{j}^{0} s_{i}^{c} / \sum_{i=1}^{N} s_{i}^{c} s_{i}^{c}
$$

When the calculated speeds are scaled by $f$ ( $i . e .$, the scaled speeds are $f s_{j}^{c}$, $i=1, N)$, they are as close as possible to the actual speeds for the current values of $\tau$ and $\theta$. Detemining $f$ and scaling the speeds should be done in subroutine OF. This scaling ability is not now in the code, but could be easily implemented by adding a few lines of new code. Then one would have the flexibility of using speeds or speed components in place of speed ratios.

\subsection{CHANGING THE ARRAY DIMENSIONS OF THE MODEL CODE AND SUPPLEMENTARY SOFTWARE}

The number of grid points that can be accommodated by the model is limited by the array dimensions within the model's code. The version of the model described in this report can handle up to 40 grid points in the $x$ and $y$ directions, and up to 10 grid points vertically (z or $\sigma$ direction). If it is desired to increase these limits, then array dimensions must be changed. The user should note that changing the size of the array dimensions can greatly affect model execution time. With $i, j$, and $k$ as the desired limits in the $x, y$, and $z$ (or $\sigma$ ) directions respectively, Figure 4.2 shows the arrays that must be changed, the locations of these arrays within the code, and the correct array dimensions. (Also shown are a few lines of code, aside from array, that must also be changed.) The array locations are indicated by the file name and the line number within the file where the array resides. Because the common block in the file "COMMONJ.INC" is part of the main program and every subroutine of the code, all of these must be compiled and linked before the model can be operated.

When the array dimensions are changed within the model, it is also necessary to change array dimensions in the supplementary software. These changes are also shown in Figure 4.2. It is important that the array dimensions of 
the model and supplementary software are the same; if they are not, the supplementary software will not work. 


\begin{tabular}{|c|c|c|}
\hline FILE NAME & $\begin{array}{c}\text { LINE } \\
\text { NUMBER } \\
\end{array}$ & CODE \\
\hline NOABL. FOR & $\begin{array}{l}18 \\
160 \\
167\end{array}$ & $\begin{array}{l}\text { DIMENSION UU }((I+1) \star J \star K), V V(I *(J+1) \star K), W W(I \star J \star(K+1)) \\
\text { DO } N=1,(I+1) \star J \star K \\
\text { DO } N=1, I \star J \star(K+1)\end{array}$ \\
\hline COMMONJ. INC & $\begin{array}{l}38 \\
39 \\
45 \\
46 \\
49 \\
52 \\
53 \\
54 \\
60\end{array}$ & $\begin{array}{l}\text { DIMENSION } X(I) \\
\text { DIMENSION } Y(J) \\
\operatorname{PI}\left(I^{\star} J\right), \operatorname{TERAIN}\left(I^{\star} J\right), \operatorname{DM} 1 A\left(I^{\star} J\right) \\
\text { DMB }\left(I^{\star} J\right) \\
\operatorname{PHI}(I+1, J+I, K+1) \\
U(I+1, J, K), V(I, J+1, K), W(I, J, K+1) \\
\text { DIV }(I, J, K), \operatorname{DZODX}\left(I^{\star} J\right), \operatorname{DZODY}\left(I^{\star} J\right) \\
\text { IFLAG }\left(I^{\star} J\right), \operatorname{UTEN}\left(I^{\star} J\right), V T E N\left(I^{\star} J\right) \\
\text { COMON }\left(4^{\star} I^{\star} J+819\right), I C O M O N\left(4^{\star} I^{\star} J+819\right)\end{array}$ \\
\hline ADJUSTUV.FOR & $\begin{array}{l}13 \\
125 \\
215 \\
216\end{array}$ & $\begin{array}{l}\text { COMMON/UUYV/UU }(I+1, J, K), V V(I, J+1, K) \\
\text { COMMON/UUVV/UU }(I+1, J, K), V V(I, J+1, K) \\
\text { DIMENSION UAVG }(I, J), V A V G(I, J) \\
\text { COMMON/UUVV/UU }(I+1, J, K), V V(I, J+1, K)\end{array}$ \\
\hline MISC.FOR & $\begin{array}{l}667 \\
672 \\
814 \\
1913\end{array}$ & $\begin{array}{l}\text { NWORDS }=4^{\star} I^{\star} J+819 \\
\text { DO } 30 N=1, I^{\star} J \\
\text { DIMENSION } H(I, J) \\
\text { DIMENSION UAVG }(I, J), \operatorname{VAVG}(I, J)\end{array}$ \\
\hline
\end{tabular}

SUPPLEMENTARY SOFTWARE

\begin{tabular}{|c|c|c|}
\hline FILE NAME & $\begin{array}{c}\text { LINE } \\
\text { NUMBER } \\
\end{array}$ & CODE \\
\hline HCONPLOT.FOR & $\begin{array}{l}8 \\
9 \\
131 \\
132\end{array}$ & $\begin{array}{l}\text { COMMON/CNB/SPEED1 }\left(I^{\star} J\right), I N P U T F I L E \\
\text { COMMON/ARRAY/ZMAT }(I, J), X C O N\left(I^{\star} J\right), Y \operatorname{CON}\left(I^{\star} J\right), Z \operatorname{CON}\left(I^{\star} J\right) \\
\text { COMMON/ARRAY/ZMAT }(I, J), X C O N\left(I^{\star} J\right), Y \operatorname{CON}\left(I^{\star} J\right), Z \operatorname{CON}\left(I^{\star} J\right) \\
\text { COMMON/CNB/SPEED }\left(I^{\star} J\right), I N P U T F I L E\end{array}$ \\
\hline COMMONJ. INC & $\begin{array}{l}38 \\
39 \\
45 \\
46 \\
49 \\
52 \\
53 \\
54 \\
60\end{array}$ & $\begin{array}{l}\text { DIMENSION } x(I) \\
\text { DIMENSION Y }(J) \\
\text { PI }\left(I^{\star} J\right), \text { TERAIN }\left(I^{\star} J\right), \text { DMIA }\left(I^{\star} J\right) \\
\text { DM8 }\left(I^{\star} J\right) \\
\text { PHI }(I+I, J+1, K+1) \\
U(I+1, J, K), V(I, J+1, K), W(I, J, K+1) \\
\text { DIV }(I, J, K), \text { DZODX }(I \star J), \quad \text { DZODY }(I \star J) \\
\text { IFLAG }(I \star J), U T E N\left(I^{\star} J\right), V T E N\left(I^{\star} J\right) \\
\text { COMON }\left(4^{\star} I^{\star} J+819\right), I C O M O N\left(4^{\star} I^{\star} J+819\right)\end{array}$ \\
\hline GETSPEED.FOR & $\begin{array}{l}7 \\
8 \\
9 \\
62 \\
63 \\
99\end{array}$ & 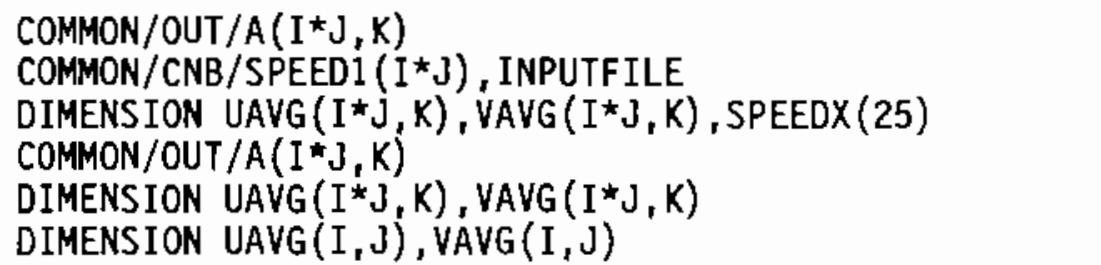 \\
\hline
\end{tabular}

FIGURE 4.2. Array Dimensions and other code changes for the Model and Supplementary Software. The maximum number of grid points in the $x, y$, and $z$ directions are $I, J$, and $K$, respectively. 
- 


\subsection{RECOMMENDATIONS AND CONCLUSIONS}

Limited testing of the optimizing version of the NOABL flow model has shown that the model can be a useful tool for micrositing in complex terrain. The model in its present form still requires sufficient expertise and sufficient computing resources to discourage some potential users. For this reason, the possibility of developing a simplified version of the model suited for a broader audience should be examined. This work could entail developing a two-dimensional model that requires less knowledge of the mathematics and that could be run on a personal computer.

It is further recommended that limitations of the model be identified with respect to:

1) wind measurement and terrain elevation density required to obtain reliable results in complex terrain

2) the range of wind speeds over which the model performs reliably.

Several model enhancements should be examined that could significantly improve model performance:

1) incorporation of appropriate physics from other models

2) incorporation of the ability to optimize on wind components

3) improvement of the wind field initialization scheme to more intelligently interpolate/extrapolate the input winds over the grid. 


\subsection{REFERENCES}

Barnard, J. C., H. L. Wegley, and T. R. Hiester. 1985. Improving the Performance of Mass-Consistent Numerical Models Using Optimization Techniques. PNL-5566, Pacific Northwest Laboratory, Richland, Washington.

Hiester, T. R., and W. T. Penne11. 1981. The Meteorological Aspects of Siting Large Wind Turbines. PNL-2522, Pacific Northwest Laboratory, Richland, washington.

Kuester, J. L., and J. H. Mize. 1973. Optimization Techniques with Fortran. McGraw-Hi1l, New York, New York.

Phillips, G. T. 1979. A Preliminary User's Guide for the NOABL Objective Analysis Code. DOETET/20280-T1, National Technical Information Service, Springfield, Virginia.

Traci, R. M., G. T. Phillips, and P. C. Patnaik. 1978. Developing a Site Selection Methodology for Wind Energy Conversion Systems. DOE/ET/ 20280-3, National Technical Information Service, Springfield, Virginia. 
.

-


APPENDIX A

NOABL INPUT VARIABLES 
APPENDIX A

NOABL INPUT VARIABLES

This appendix lists the input variables to the NOABL model. This listing is taken from the NOABL user's guide (Phillips 1979). Only a subset of the listed variables is required as user-specified input to the model described in this report. 
. 


\begin{tabular}{|c|c|c|c|c|}
\hline VARIABLE & LOCATION & TYPE & DEFAULT & DEFINITION \\
\hline \multirow[t]{2}{*}{ ALFA1 } & 1 & Real & 0.70710678 & $\begin{array}{l}\text { Defines horizontal trans- } \\
\text { missivity }\end{array}$ \\
\hline & & & & $\tau_{\mathrm{h}}=1.0 /\left(2.0 * \mathrm{ALFAI} \star^{*} 2\right)$ \\
\hline \multirow[t]{2}{*}{ ALFA2 } & 2 & Real & $0.70710678^{\circ}$ & $\begin{array}{l}\text { Defines vertical trans- } \\
\text { missivity }\end{array}$ \\
\hline & & & & $\tau_{v}=1.0 /(2.0 * A L F A 2 * \star 2)$ \\
\hline ATOP & 343 & Real & & $\begin{array}{l}\text { Wind direction at top of } \\
\text { mesh (degrees) }\end{array}$ \\
\hline BETA & 3 & Real & 0.1429 & $\begin{array}{l}\text { Exponent of power law } \\
\text { profile }\end{array}$ \\
\hline \multirow[t]{2}{*}{ DBUG } & 5 & Integer & 0 & Debug flag \\
\hline & & & & $\begin{array}{l}0: \text { no debug edit } \\
1: \text { turn on debug edits }\end{array}$ \\
\hline \multirow[t]{2}{*}{ DMP } & 39 & Real & 0.0 & $\begin{array}{l}\text { Damping factor for con- } \\
\text { formal simulations of } \\
\text { highly stable flow; } \\
\text { suggest: }\end{array}$ \\
\hline & & & & DMP $\sim .05 \rightarrow .1$ for $\tau_{\mathrm{v}}<.01$ \\
\hline$D X$ & 6 & Real & 2000.0 & $\begin{array}{l}\text { Constant zone size in } \\
x \text {-direction (east) }(m)\end{array}$ \\
\hline DY & 7 & Real & 2000.0 & $\begin{array}{l}\text { Constant zone size in } \\
\text { y-direction (north) }(m)\end{array}$ \\
\hline $\mathrm{DZ}$ & 8 & Real & & $\begin{array}{l}\text { Constant zone size in } \\
\text { z-direction (vertical) (m). } \\
\text { Set for real space runs } \\
\text { only. }\end{array}$ \\
\hline DZMIN & 9 & Real & 30.0 & $\begin{array}{l}\text { Minimum vertical zone size } \\
\text { (m). Specified when } \\
\text { ISIG }=3 \text {. }\end{array}$ \\
\hline
\end{tabular}




\begin{tabular}{|c|c|c|c|c|}
\hline AARIABLE & LOCATION & TYPE & DEFAULT & DEFINITION \\
\hline EPSLN & 10 & Real & 0.1 & $\begin{array}{l}\min \Delta \phi_{j j k} \rightarrow \text { conformal space } \\
\min \operatorname{Div}_{i j k} \rightarrow \text { real space }\end{array}$ \\
\hline \multirow[t]{2}{*}{$\mathrm{I} 2 \mathrm{D}$} & 23 & Integer & 0 & Space dimension flag \\
\hline & & & & $\begin{array}{l}0: 3-0 \text { space }(x, y, z \text { or } \sigma) \\
1: 2-0 \text { space }(x, y \text { or } \sigma)\end{array}$ \\
\hline IDAY & 11 & Integer & 1 & $\begin{array}{l}\text { Day of month being } \\
\text { simulated }\end{array}$ \\
\hline \multirow[t]{2}{*}{ IEDIT } & 12 & Integer & 0 & Edit flag \\
\hline & & & & $\begin{array}{l}\text { 0: no edit of flow variables } \\
\text { 1: edit flow variables } \\
\text { 2: generate line printer } \\
\text { contour plots } \\
\text { 3: generate summary edit } \\
\text { plus line printer contour } \\
\text { plots on unit } 9\end{array}$ \\
\hline IHOUR & 13 & Integer & 1 & Hour of day being simulated \\
\hline IMAX & 14 & Integer & 30 & $\begin{array}{l}\text { Maximum number of cells in } \\
x \text {-direction (east) }\end{array}$ \\
\hline IMN & 15 & Integer & 1 & $\begin{array}{l}\text { Minimum column in } \\
\text { I-direction to be edited }\end{array}$ \\
\hline IMX & 16 & Integer & 30 & $\begin{array}{l}\text { Maximum column in } \\
\text { I-direction to be edited }\end{array}$ \\
\hline \multirow[t]{2}{*}{ IPATH } & 17 & Integer & 2 & Geometry flag \\
\hline & & & & $\begin{array}{l}\text { 1: real space } \\
\text { 2: conformal space }\end{array}$ \\
\hline \multirow[t]{2}{*}{ ISIG } & 18 & Integer & 3 & $\begin{array}{l}\text { Vertical zoning flag } \\
\text { (conformal space only) }\end{array}$ \\
\hline & & & & $\begin{array}{l}\text { 1: } \log \text { linear distribution } \\
\text { 2: constant zoning } \\
3: \text { geometric progression }\end{array}$ \\
\hline
\end{tabular}




\begin{tabular}{|c|c|c|c|c|}
\hline VARIABLE & LOCATION & TYPE & DEFAULT & DEFINITION \\
\hline ITERAN & 19 & Integer & 3 & $\begin{array}{l}\text { Terrain data source flag } \\
\text { 1: read terrain data from } \\
\text { tape (unit } 8 \text { ) [8F10.2 } \\
\text { format] } \\
2 \text { : initialize terrain data } \\
\text { from data statement } \\
\text { 3: read terrain data from } \\
\text { cards [10F8.1 format] }\end{array}$ \\
\hline ITMAX & 40 & Integer & 100 & $\begin{array}{l}\text { Maximum allowable number of } \\
\text { iterations }\end{array}$ \\
\hline ITYLOR & 20 & Integer & 0 & $\begin{array}{l}\text { Special edit flag } \\
0: \text { no special edit } \\
1: \text { interpolate adjusted field } \\
\text { to define wind speed and } \\
\text { direction at specified } \\
\text { locations within the mesh }\end{array}$ \\
\hline IWIND & 21 & Integer & 1 & $\begin{array}{l}\text { Wind data type flag } \\
\text { 1: surface wind data only, } \\
\text { input wind speed and } \\
\text { direction } \\
\text { 2: surface wind data only, } \\
\text { input wind components } \\
\text { 3: surface wind data and one } \\
\text { upper air station, input } \\
\text { wind speed and direction } \\
\text { 4: surface wind data and one } \\
\text { upper air station, input } \\
\text { wind components }\end{array}$ \\
\hline IYEAR & 22 & Integer & 1 & Simulation year \\
\hline JMAX & 24 & Integer & 30 & $\begin{array}{l}\text { Maximum number of cells in } \\
\text { y-direction (north) }\end{array}$ \\
\hline JMN & 25 & Integer & 1 & $\begin{array}{l}\text { Minimum column in J-direction } \\
\text { to be edited }\end{array}$ \\
\hline JMX & 26 & Integer & 30 & $\begin{array}{l}\text { Maximum column in j-direction } \\
\text { to be edited }\end{array}$ \\
\hline
\end{tabular}




\begin{tabular}{|c|c|c|c|c|}
\hline VARIABLE & LOCATION & TYPE & DEFAULT & DEFINITION \\
\hline KMAX & 27 & Integer & 15 & $\begin{array}{l}\text { Maximum number of cells in } \\
\text { vertical direction }\end{array}$ \\
\hline KMN & 28 & Integer & 1 & Minimum row to be edited \\
\hline KMX & 29 & Integer & 15 & Maximum row to be edited \\
\hline MONTH & 30 & Integer & 1 & Month of simulation \\
\hline MPS & 31 & Integer & 1 & $\begin{array}{l}\text { Wind speed units flag } \\
0 \text { : input is } \mathrm{mph} \\
1 \text { : input is } \mathrm{m} / \mathrm{sec} \\
2 \text { : input is knots }\end{array}$ \\
\hline NDAYS & 32 & Integer & 1 & $\begin{array}{l}\text { Number of separate simula- } \\
\text { tions to be performed }\end{array}$ \\
\hline \multirow[t]{2}{*}{ NPTS } & 33 & Integer & 1 & $\begin{array}{l}\text { Number of wind observation } \\
\text { stations }\end{array}$ \\
\hline & & & & $\begin{array}{l}-1: \text { initialization with } \\
\text { upper air data only }\end{array}$ \\
\hline NSTAT & 291 & Integer & 0 & $\begin{array}{l}\text { Number of stations where wind } \\
\text { speed and wind direction are } \\
\text { to be computed for editing } \\
\text { purposes. If NSTAT is } \\
\text { negative, } 4 \text { character } \\
\text { Hollerith station I.D. 's are } \\
\text { to be entered via card input }\end{array}$ \\
\hline NUA & 345 & Integer & 2 & $\begin{array}{l}\text { Number of upper air reporting } \\
\text { levels }\end{array}$ \\
\hline \multirow[t]{2}{*}{ OMEG } & 34 & Real & -1.0 & $\begin{array}{l}\text { Over-relaxation parameter set } \\
\text { to }-1.0 \text { in DEFINE, used } \\
\text { initially as a flag }\end{array}$ \\
\hline & & & & $\begin{aligned}-1.0: & \text { OMEG is calculated } \\
>0 & : \text { OMEG was entered through } \\
& \text { cards }\end{aligned}$ \\
\hline $\begin{array}{l}\text { ORIGNX } \\
\text { ORIGNY }\end{array}$ & 35,36 & Real & $0.0,0.0$ & Position of grid origin (m) \\
\hline
\end{tabular}




\begin{tabular}{|c|c|c|c|c|}
\hline VARIABLE & LOCATION & TYPE & DEFAULT & DEFINITION \\
\hline QTOP & 342 & Real & 999.0 & $\begin{array}{l}\text { Wind speed at top of mesh, if } \\
\text { QTOP }=999.0 \text { wind speed at top } \\
\text { of mesh is assumed equal to } \\
\text { that at top of boundary layer } \\
\text { (m/sec, mph, knots) }\end{array}$ \\
\hline ZBL & 344 & Real & 200.0 & $\begin{array}{l}\text { Boundary layer height (AGL) } \\
(m)\end{array}$ \\
\hline ZDIST & 38 & Real & $\begin{array}{l}2 \star[\text { Range of } \\
\text { Terrain } \\
\text { Heights }]\end{array}$ & $\begin{array}{l}\text { Height of top boundary with } \\
\text { respect to minimum terrain } \\
\text { altitude (m) }\end{array}$ \\
\hline UAMSL & 396 & Real Array & & $\begin{array}{l}\text { Array of upper level heights } \\
\text { (MSL) corresponding to } \\
\text { reported upper level winds } \\
\text { (m) }\end{array}$ \\
\hline WDR & 41 & Real Array & & $\begin{array}{l}\text { Array of observed surface } \\
\text { wind direction or V-compo- } \\
\text { nents (degrees, m/sec, mph, } \\
\text { or knots) }\end{array}$ \\
\hline WDRUA & 371 & Real Array & & $\begin{array}{l}\text { Array of observed upper air } \\
\text { wind direction or V-components } \\
\text { read from lowest level to } \\
\text { highest level (degrees, } \mathrm{m} / \mathrm{sec} \text {, } \\
\text { mph, or knots) }\end{array}$ \\
\hline WSPD & 91 & Real Array & & $\begin{array}{l}\text { Array of observed surface } \\
\text { wind speeds or U-components } \\
\text { (m/sec, mph, or knots) }\end{array}$ \\
\hline WSPDUA & 346 & Real Array & & $\begin{array}{l}\text { Array of observed upper air } \\
\text { wind speeds or U-components } \\
\text { read from lowest level to } \\
\text { highest level (m/sec, mph, or } \\
\text { knots) }\end{array}$ \\
\hline$x_{0}$ & 141 & Real Array & & $\begin{array}{l}\text { Array of } x \text {-positions of } \\
\text { observed wind velocities (m) }\end{array}$ \\
\hline XSTA & 292 & Real Array & & $\begin{array}{l}\text { X-locations of each of NSTAT } \\
\text { stations }(\mathrm{m})\end{array}$ \\
\hline
\end{tabular}




$\begin{array}{lccc}\begin{array}{lcc}\text { VARIABLE } \\ \text { Y0 }\end{array} & \frac{\text { LOCATION }}{191} & & \text { Real Array } \\ \text { YSTA } & 317 & \text { Real Array } \\ \text { Z0 } & 241 & \text { Real Array }\end{array}$

DEFINITION
Array of Y-positions of
observed wind velocities (m)
Y-locations of each of NSTAT
stations (m)
Array of Z-positions (AGL)
of observed wind velocities
(m)


APPENDIX B

MODEL LISTING 
APPENDIX B

MODEL LISTING

The model code is broken up into 9 files; this appendix lists these files. One of the files, COMMONJ. INC, contains a common block that is shared by most code modules. The files are listed in the following order:
1) NOABL.FOR
2) COMMONJ.INC
3) ADJUSTUV.FOR
4) LINTERP. FOR
5) MISC.FOR
6) NEHMIN, FOR
7) OF.FOR
8) OFI.FOR
9) STABR.FOR

To make executable code, all these files, except comMONJ. INC, must be compiled and linked. A link command such as

LINK/EXE=MODEL. EXE NOABL, ADJUSTUV, LINTERP, MISC, NEWMIN, OF , OF1, STABR

produces the executable code MODEL. EXE. 
, 
FILE: NOABL.FOR

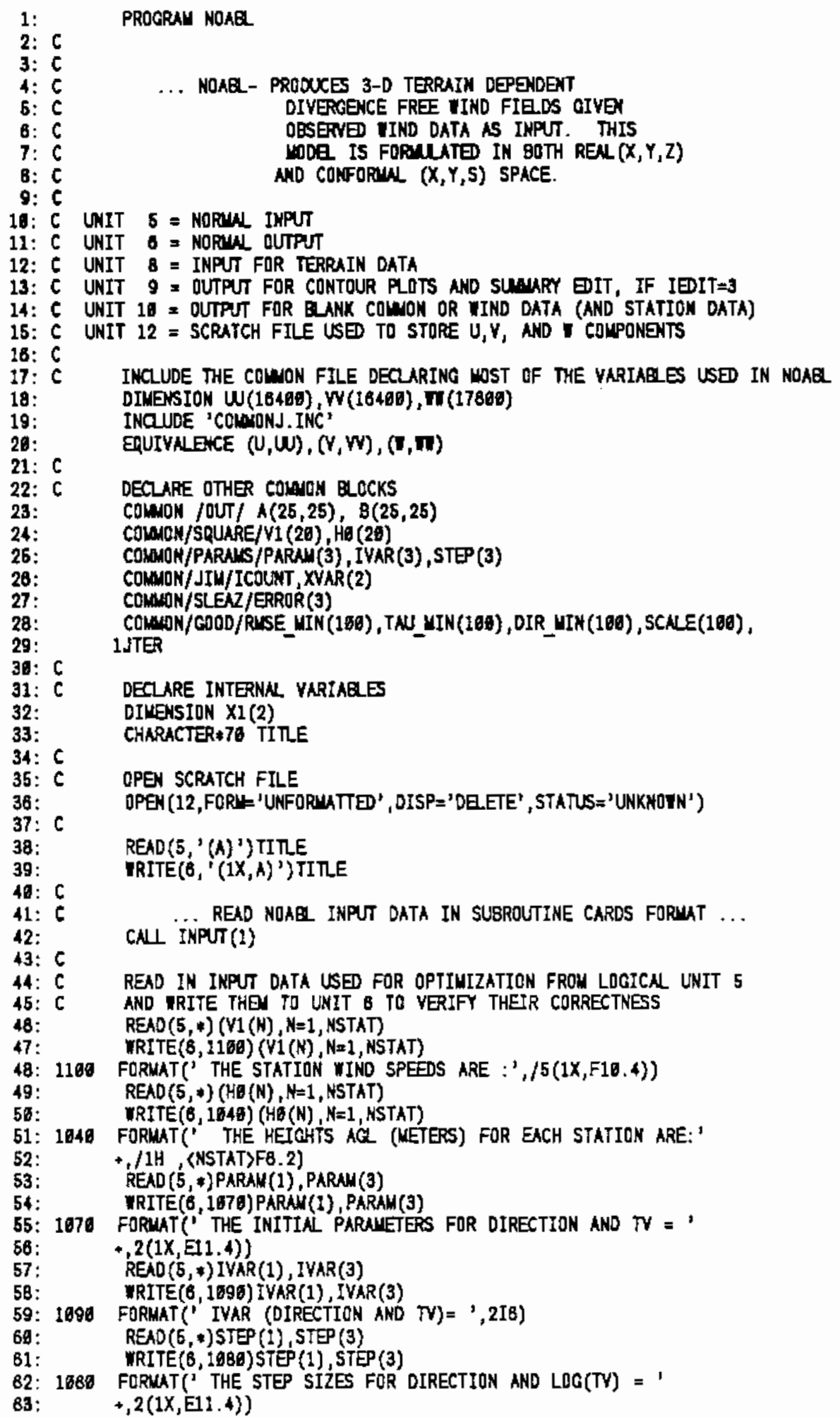




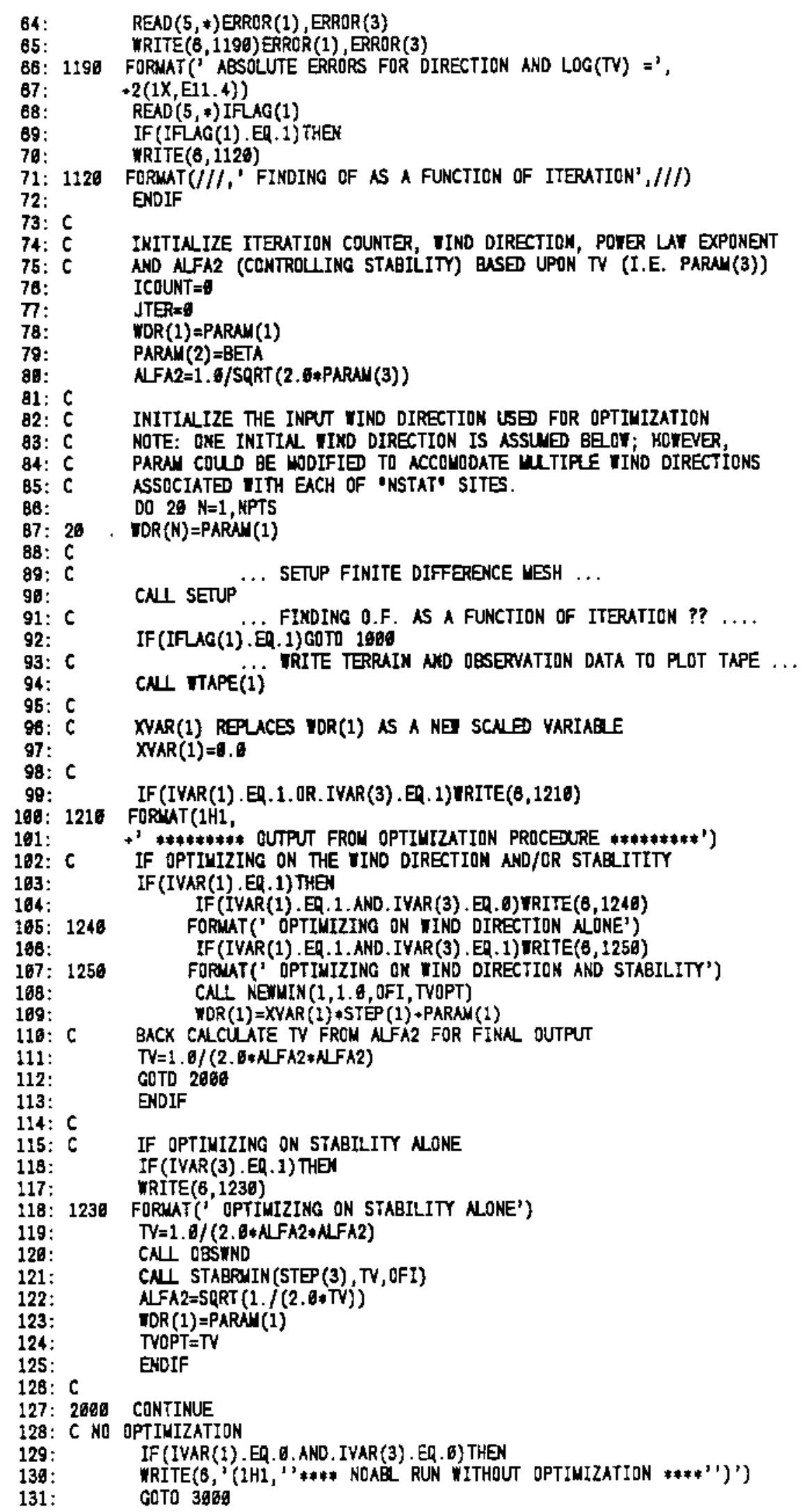




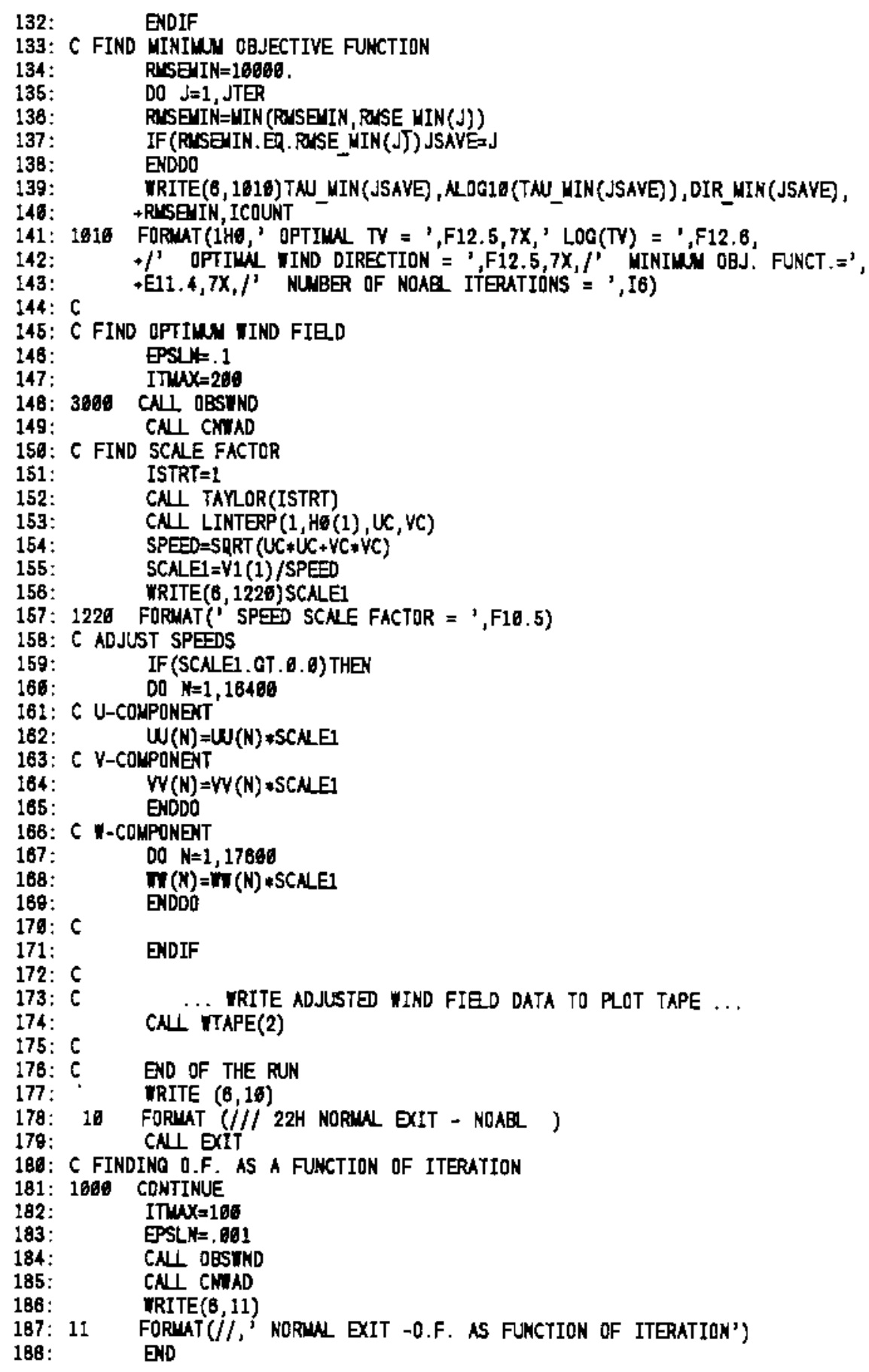


FILE: COMMONJ. INC

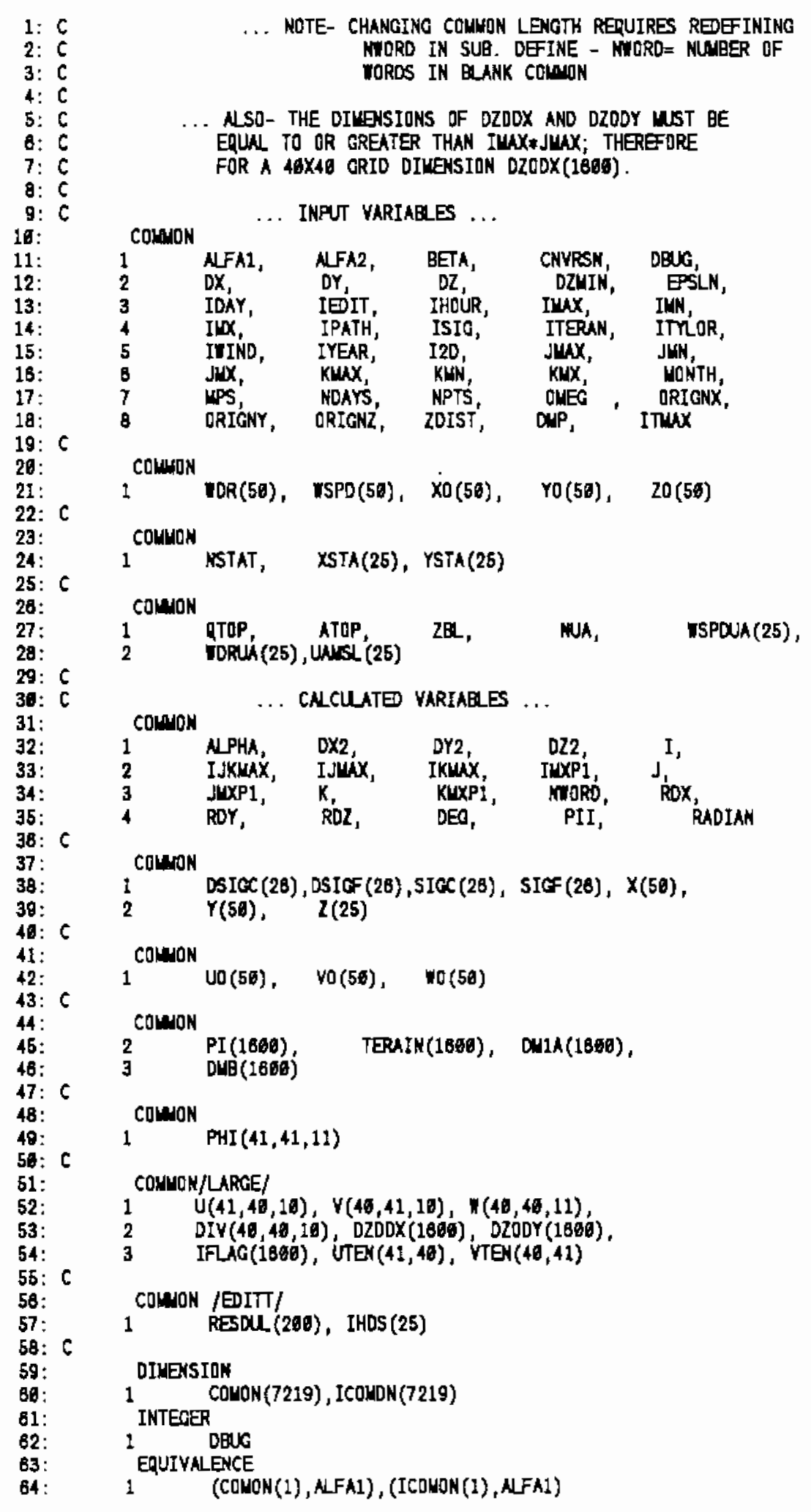




\section{FILE: ADUUSTUV.FDR}

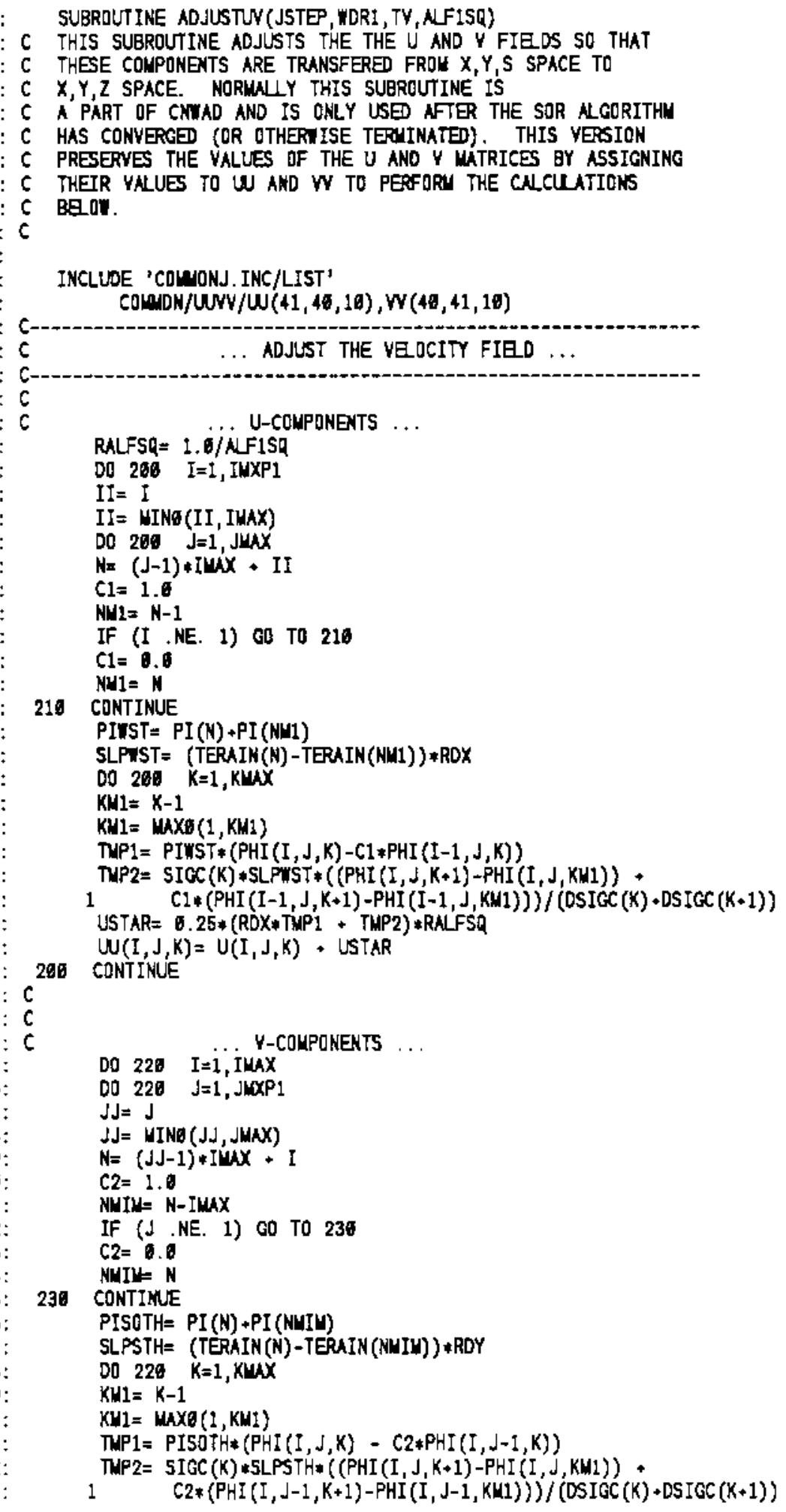

$$
\text { : }
$$

$$
\text { 1:: }
$$$$
\text { 2: }
$$$$
\text { 3: }
$$$$
\text { 4: }
$$$$
\text { 3: : }
$$

41:

42: $C$

43: C

44: $C$

45:

48:

47:

48:

49:

50 :

51:

52:

54 :

55:

58 :

57:

59:

60:

61:

62:

63 : 


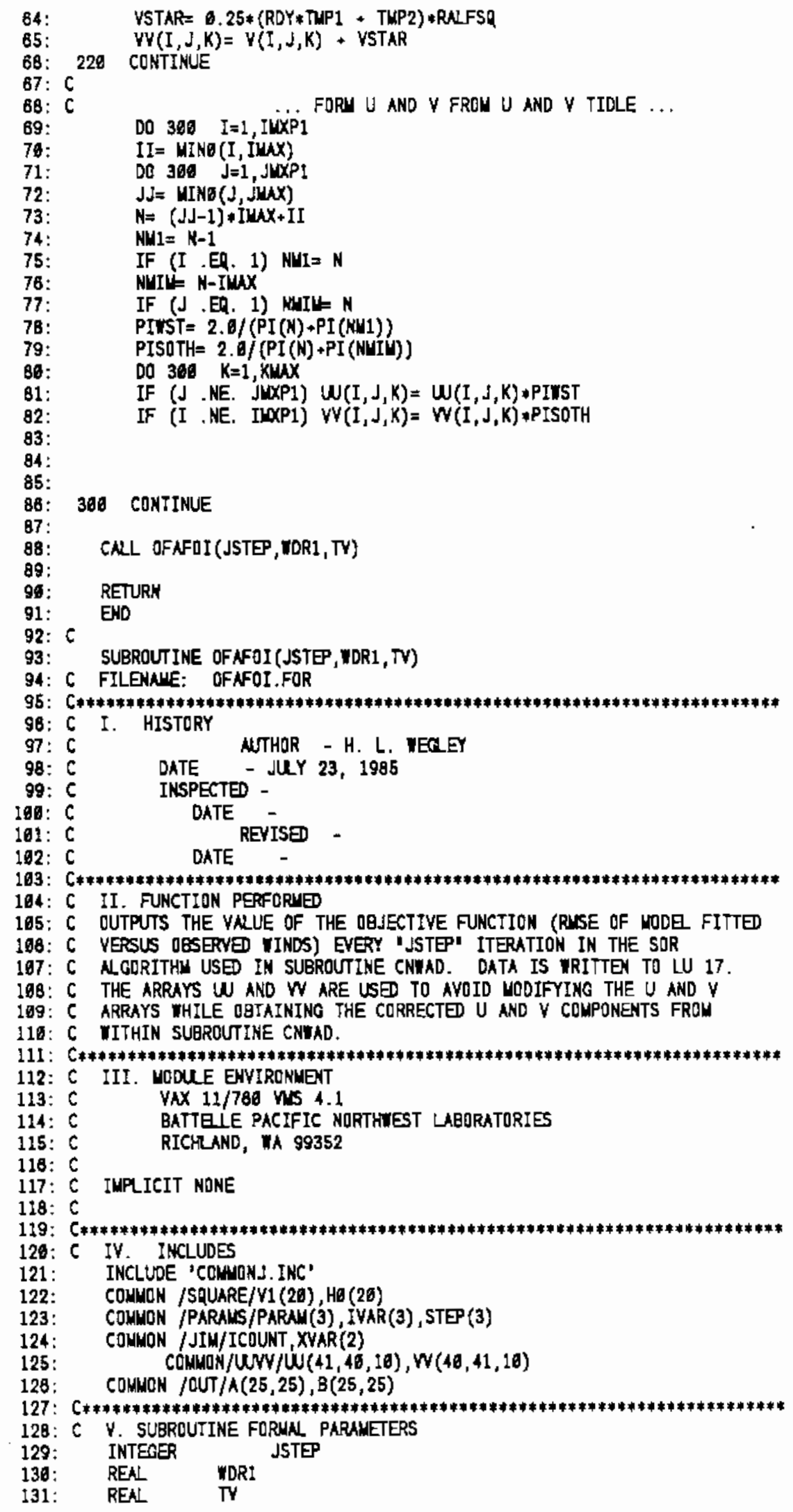




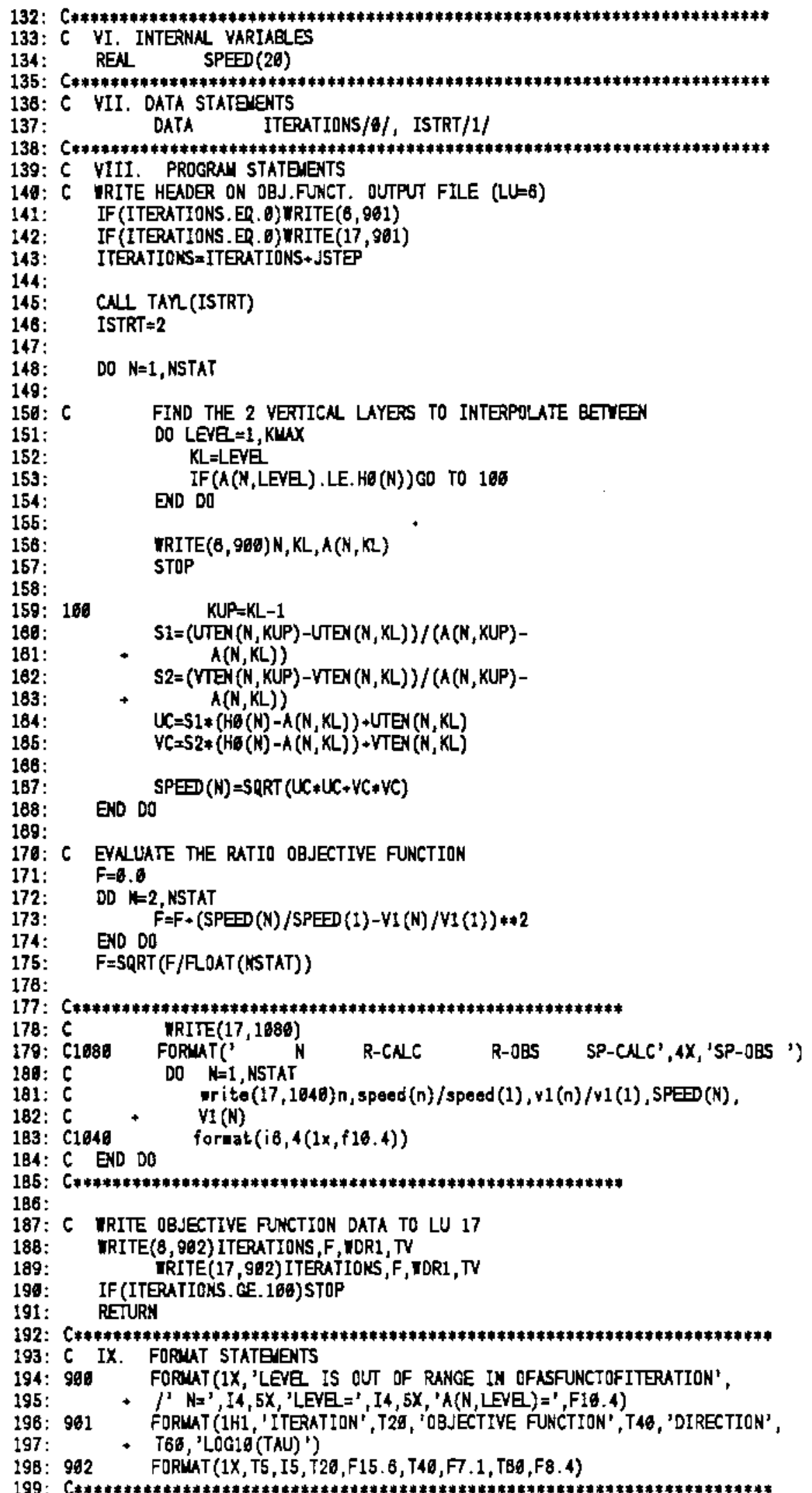




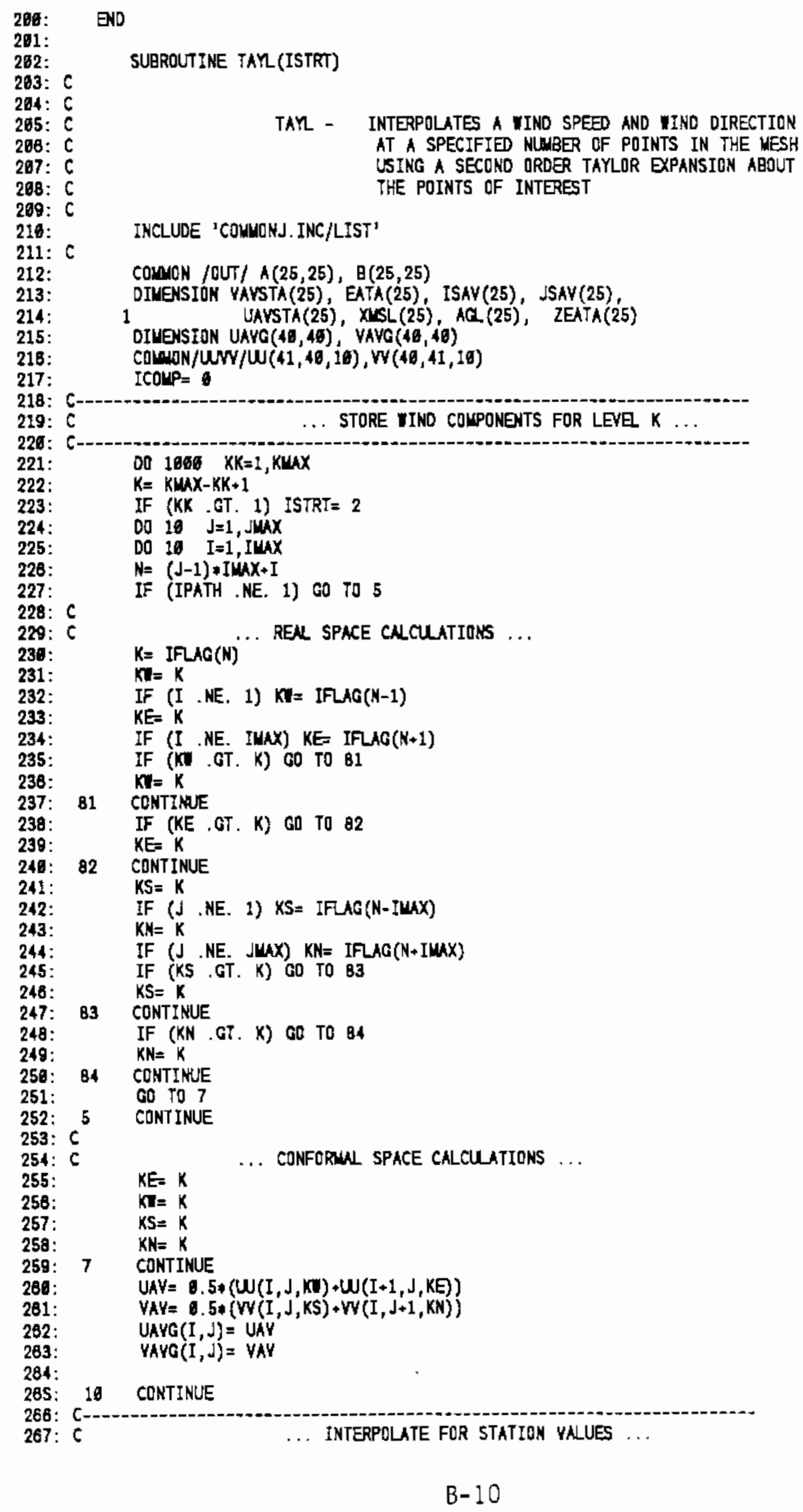

252:

253: $C$

254: $C$

255:

258:

257:

25a:

259:

280:

261:

282:

263:

284:

28S: 10 CONTINUE

OO $1060 \quad K K=1, K U A X$

$k=k m x-k K+1$

IF (KK.GT. 1) ISTRT $=2$

Do $10 \mathrm{~J}=1, \mathrm{~J} m \mathrm{x}$

DO $10 \mathrm{I}=1$, I wax

$N=(J-1) * I M X+I$

IF (IPATH. NE. 1) GO TO 5

$K=\operatorname{IFLAG}(N)$

$\mathbf{K N}=\mathbf{K}$

IF (I . NE. 1) $K=\operatorname{IFLAG(N-1)}$

$\mathrm{KE}=\mathrm{K}$

IF (I .NE. INAX) KE- IFLAG(K+1)

IF (KW .GT. K) CO TO BI

$\mathbf{K} \mathbf{W}=\mathbf{K}$

81 CONTINUE

IF (KE , GT. K) GD TO 82

82 CONTINUE

KS $=K$

IF (J.NE. 1) XS= IF_AG (N-IUAX)

$K N=K$

IF (J.NE. JUAX) KN=IFLAG(N+IMX)

IF (KS .GT. K) GO TO 83

$\mathrm{KS}=\mathrm{K}$

83 CONTINUE

IF (KN .GT. K) GO TO 84

$\mathrm{KN}=\mathrm{K}$

84 CONTIHUE

GO TO 7

CONT INUE

267: $C$

$K E=K$

... CONFORML SPACE CALCUATIONS ...

$K \mathbf{T}=K$

$\mathrm{KS}=\mathrm{K}$

$\mathrm{KN}=\mathrm{K}$

CONTINUE

$U A V=0.5 *\{W(I, J, K U)+W(I+1, J, K E)$

$V A Y=.5 *(V W(I, J, K S)+V(I, J+1, K N))$

$\operatorname{UAYG}(I, J)=\operatorname{UAY}$

VAVG $(I, J)=$ VAY 


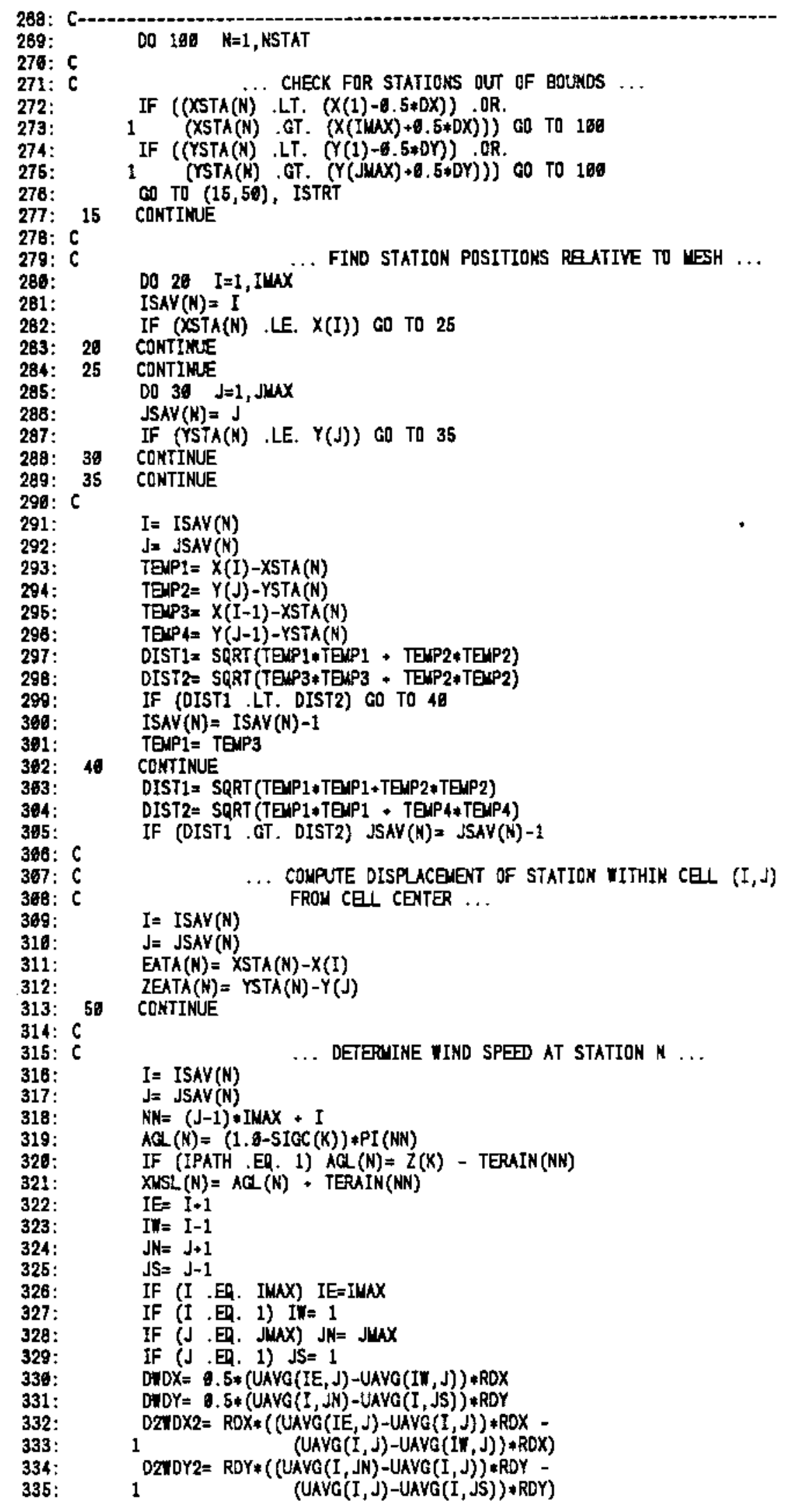




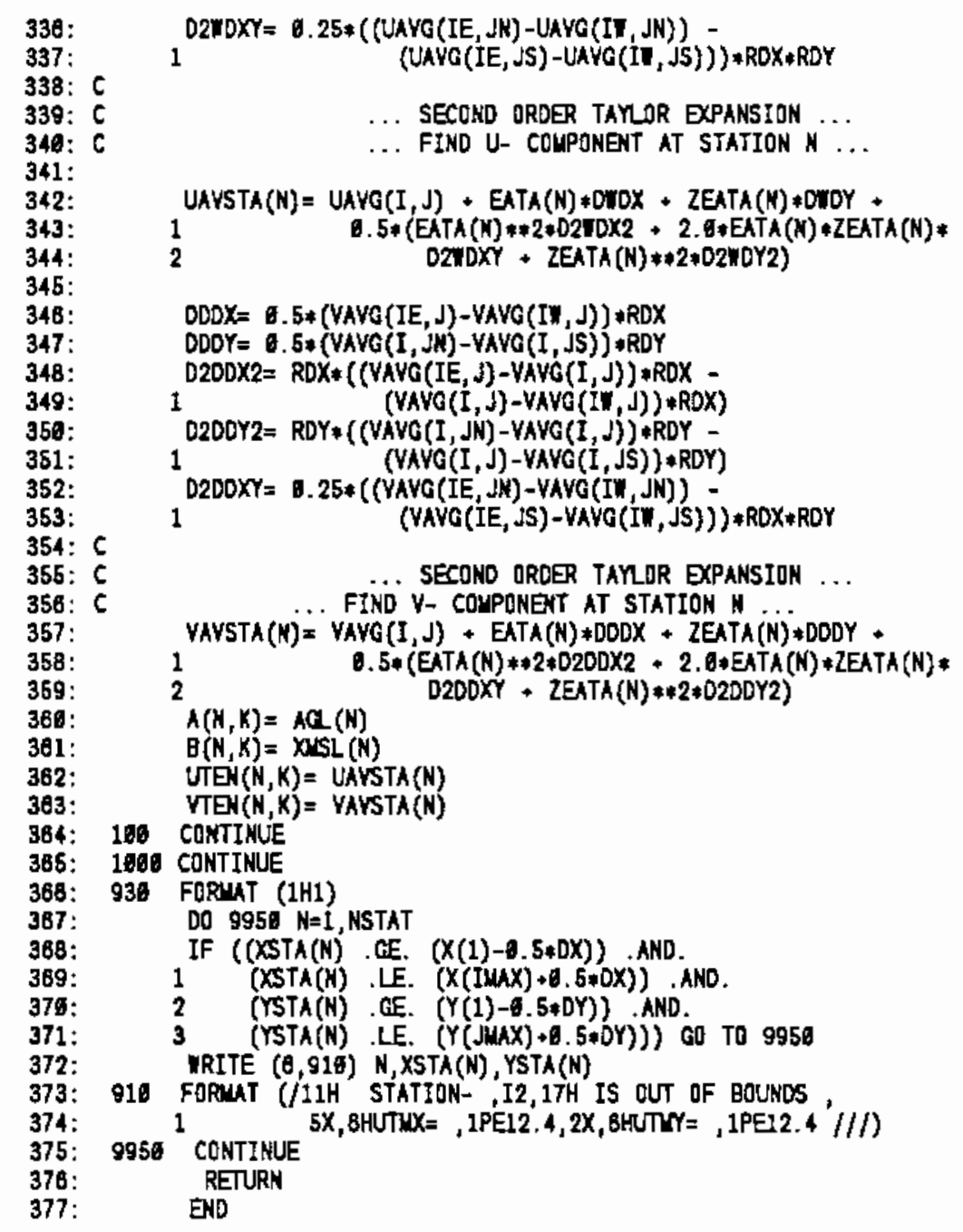




\section{FILE： LINTERP.FOR}

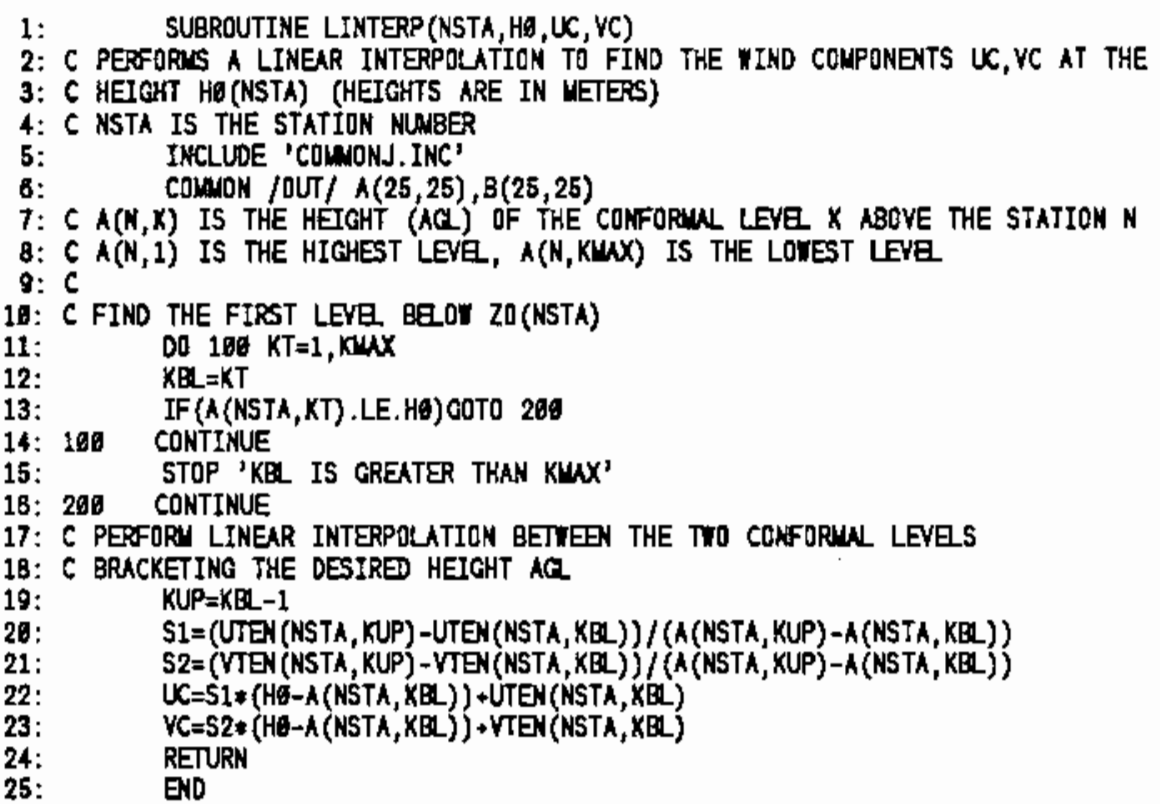


FILE: MISC.FOR

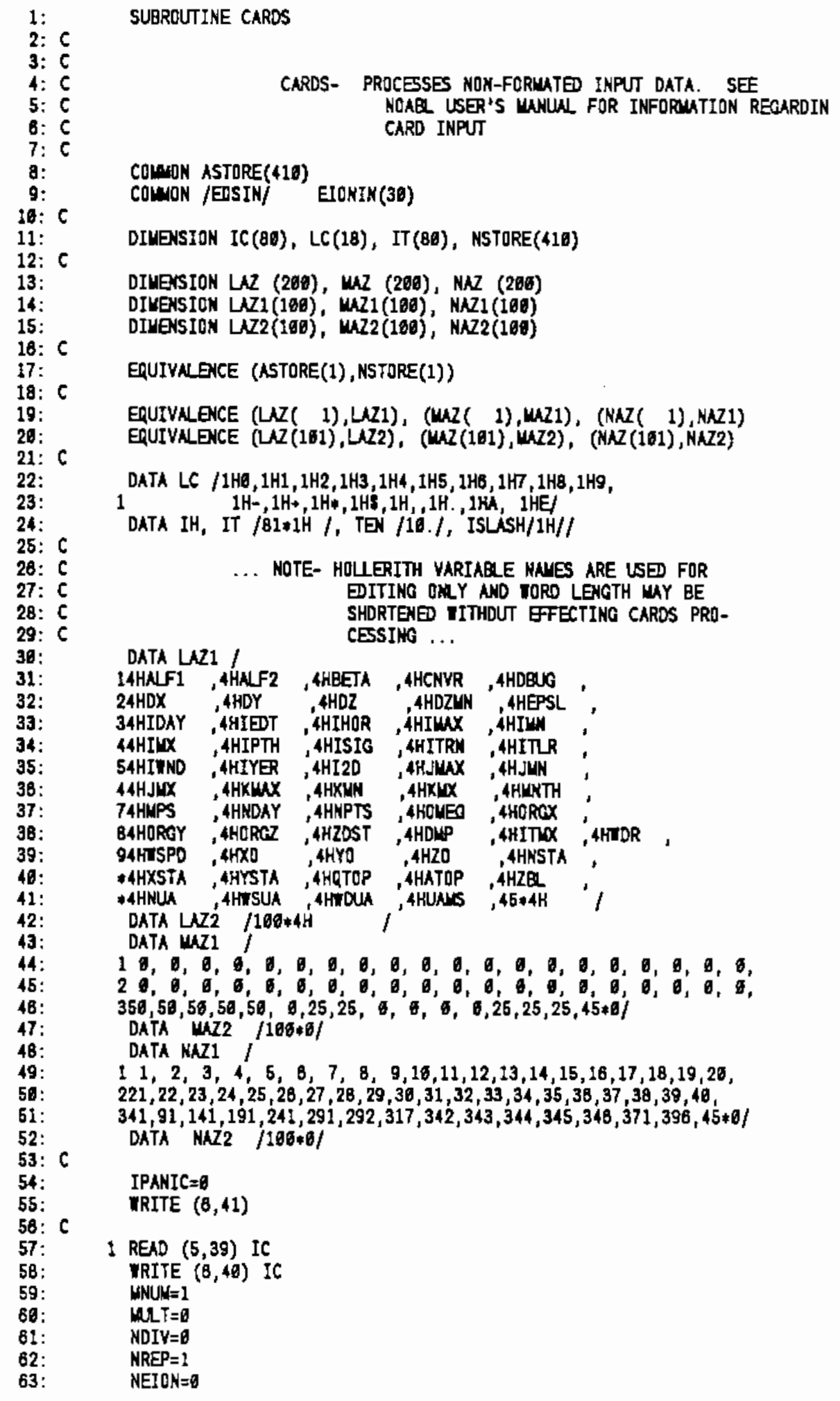




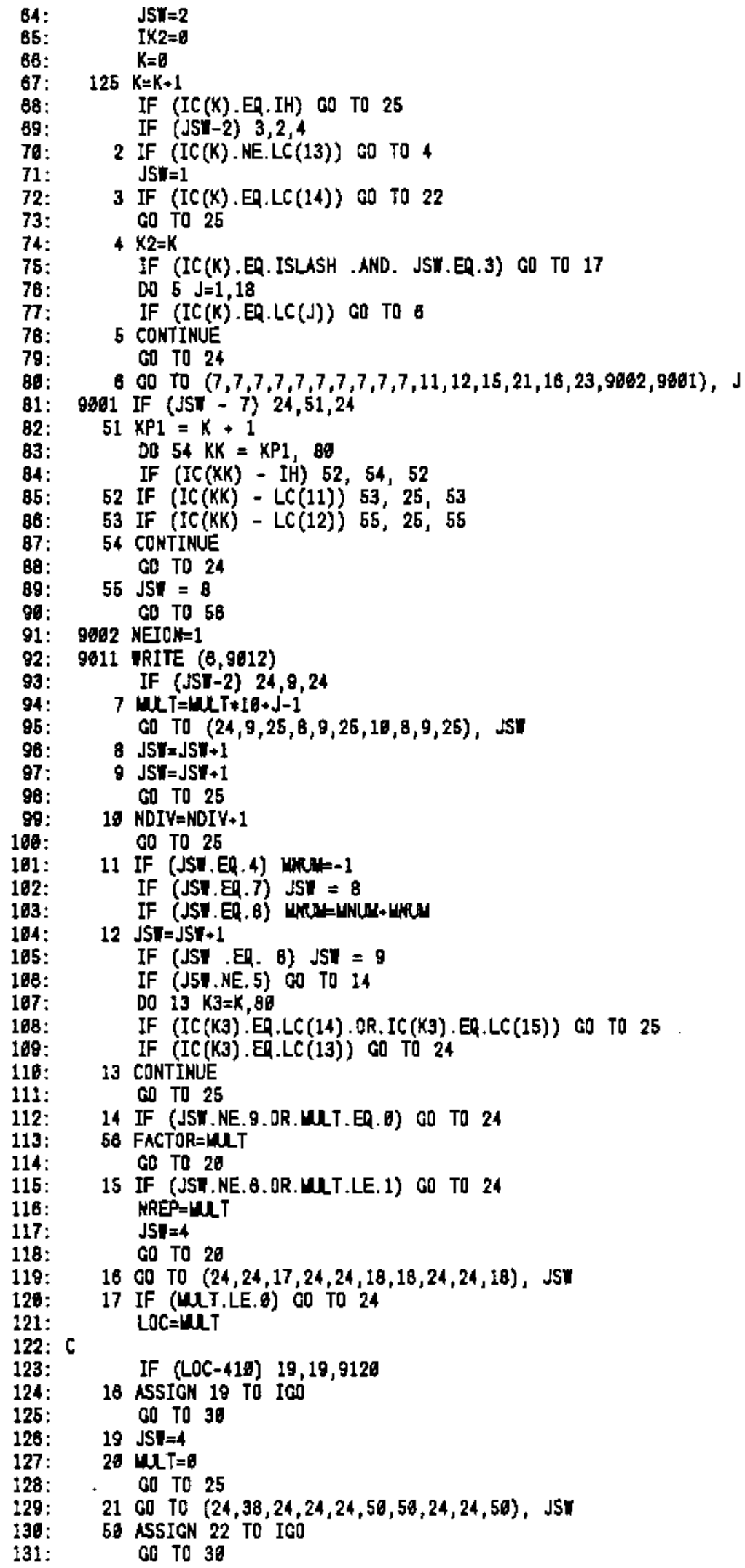




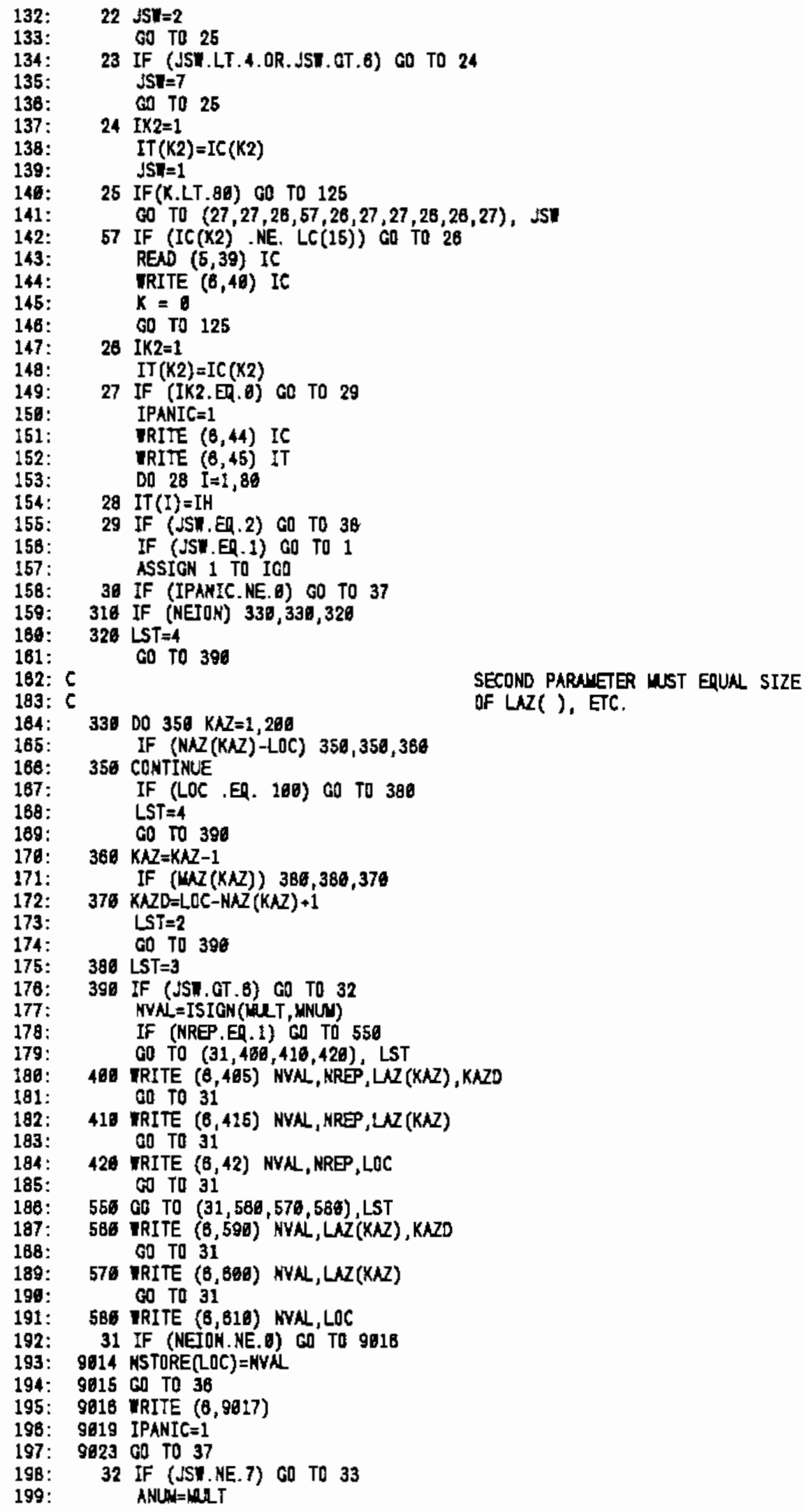




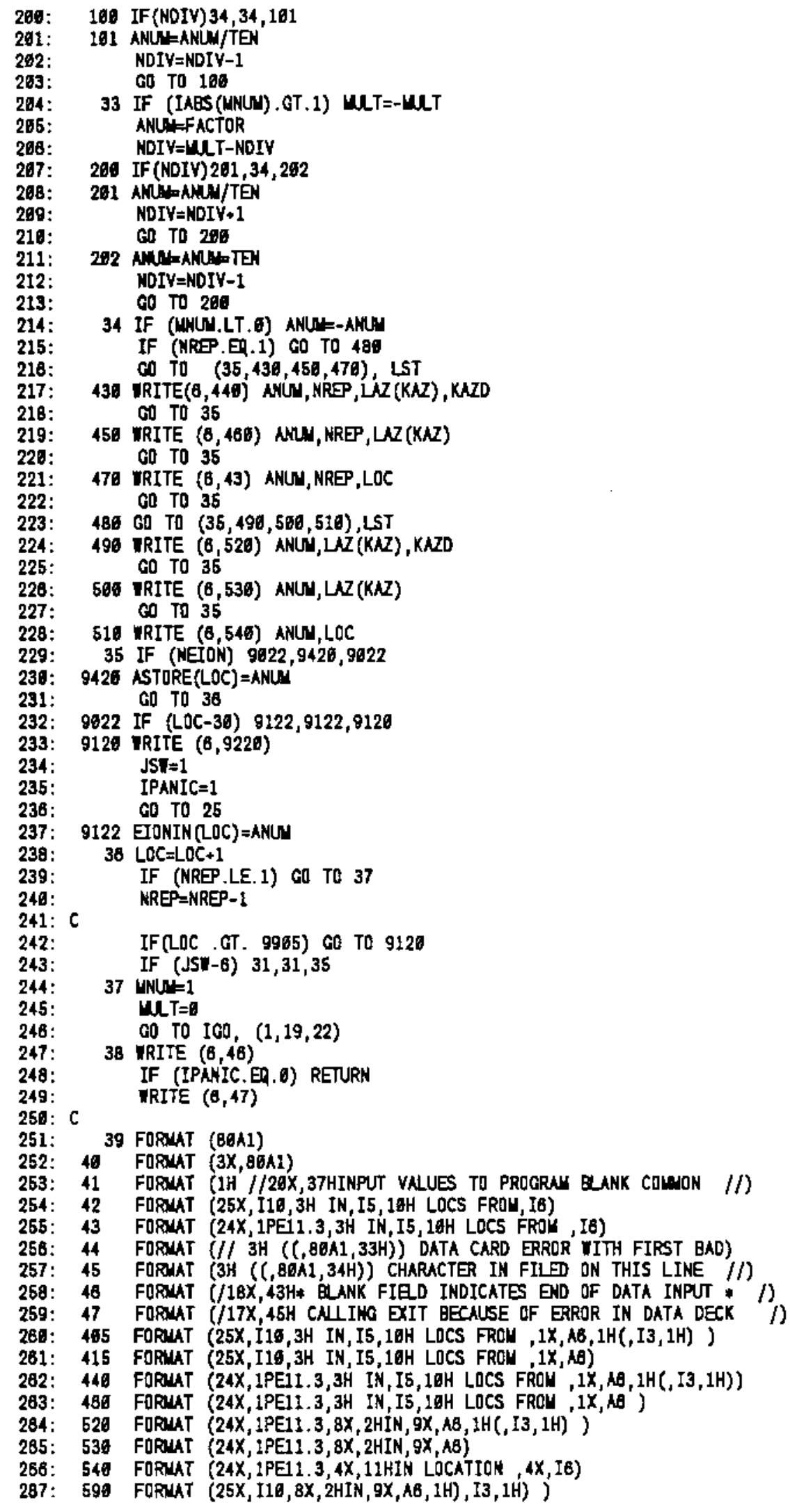




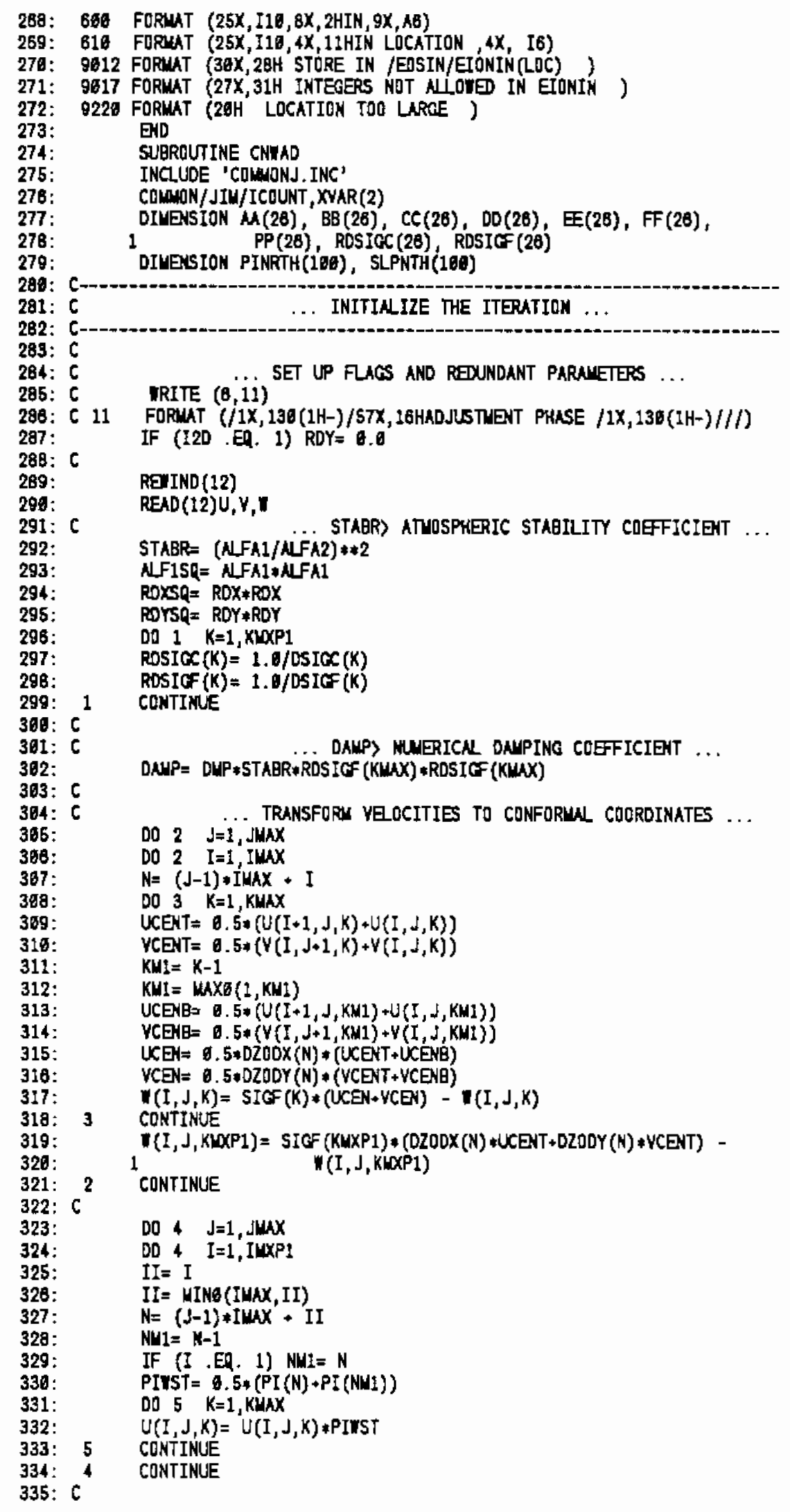




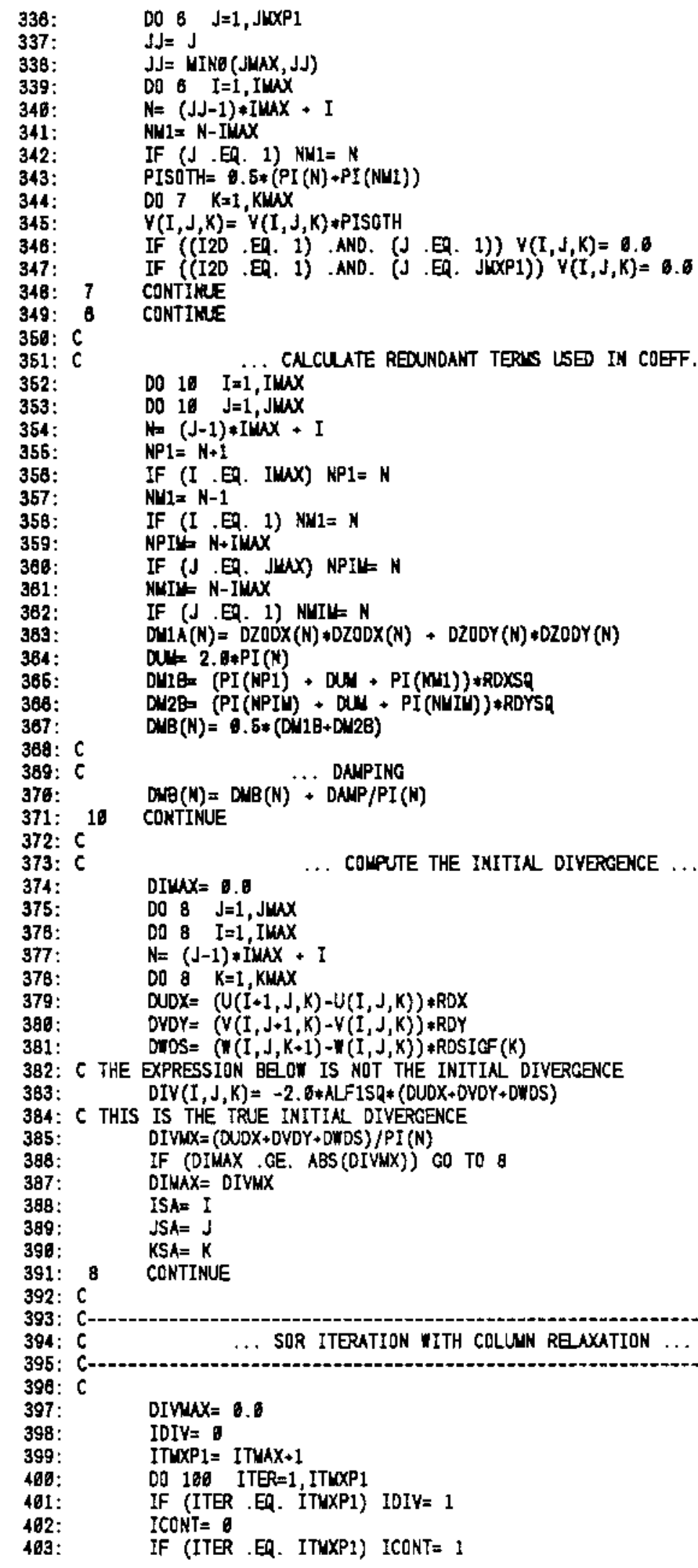

$357:$

358:

359:

386: IF ( $J$ EQ JWAX) NPIL $N$

381: $\quad$ NMIN= N-IWWX

362: IF (J.EA. 1) NUIL $N$

383: $\quad \operatorname{DU1} A(N)=\operatorname{DZODX}(N) * \operatorname{DZODX}(N)+\operatorname{DZODY}(N) * \operatorname{DZOOY}(N)$

384: DUF 2. B*PI(N)

365: $\quad$ DHIO $(\mathrm{PI}(\mathrm{NP1})+\mathrm{DUN}+\mathrm{PI}(\mathrm{M} 1))+$ RDXS9

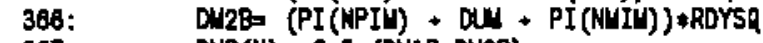

367: $\quad D^{N B}(\mathrm{H})=0.5 *\left(\mathrm{DN}_{1} \mathrm{~B}+\mathrm{DN}^{N} \mathrm{OB}\right)$

388: C $C$. D DAPING

376: $\quad \operatorname{DNO}(\mathrm{N})=\operatorname{DNB}(\mathrm{N})+\operatorname{DNA} / \mathrm{PI}(\mathrm{N})$

371: 10 CONTINUE

372: $C$

373: $C$

374:

375: $\quad$ DO $8 \mathrm{~J}=1$, Junx

378: $\quad$ DO $8 \quad I=1, \operatorname{IMAX}$

377: $\quad N=(J-1) * I M A X+I$

378: $\quad$ DO \& $K=1, \mathrm{KMAX}$

379: $\quad$ DUDX $=(U(I+1, J, K)-U(I, J, K)) * R D X$

380: $\quad$ OVDY $=(V(I, J+1, K)-V(I, J, K)) * R D Y$

381: $\quad$ DTOS $=(M(I, J, K+1)-W(I, J, K)) * \operatorname{ROSICF}(K)$

382: $c$ THE EXPRESSION BE ON IS NOT THE INITIAL DIVERGENCE

383: $\quad \operatorname{DIV}(I, J, K)=-2.6 * A L F 1 S Q *$ (DUDX+DVOY+DWDS)

384: $C$ THIS IS THE TRUE INITIAL DIVERGENCE

385: $\quad$ DIVWX $=($ OUDX + DVDY $+D W D S) / P I(N)$

388: IF (DIMAX.GE. ABS (OIVMX)) GO TO 8

387: DIMAX = DIVMX

388: $\quad$ ISA $=I$

389: $\quad J S A=J$

398: $\quad K S A=K$

391: 8 CONTINUE

392: $\mathrm{C}$

393:

394:

395:

398:

397:

398:

399 :

400:

401: IF (ITER. ES. ITMXP1) IDIY= 1

402: $\quad$ ICONT $=0$

463: IF (ITER .ES. ITMXP1) ICONT= 1 


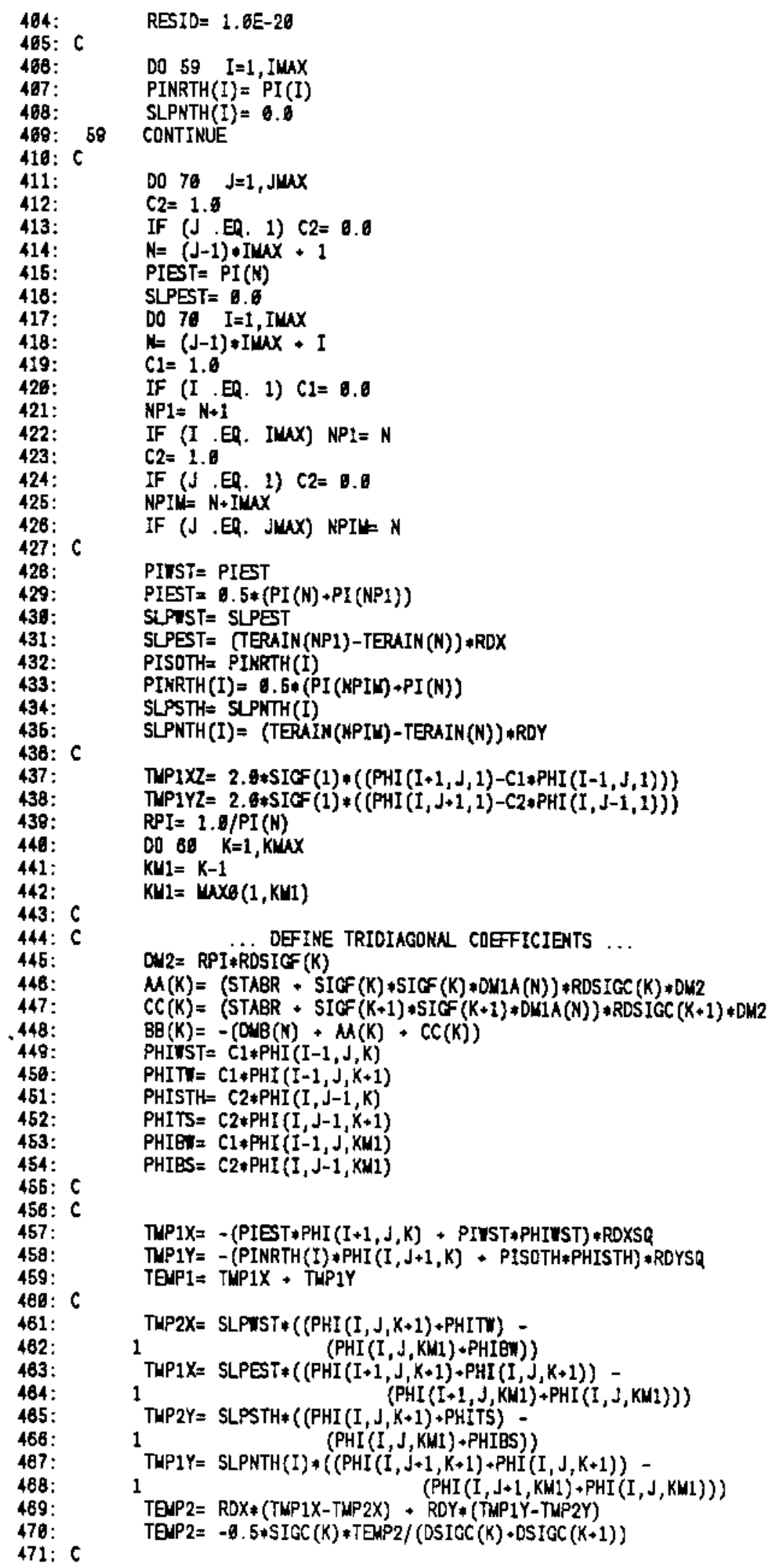

440:

441:

442:

443: $C$

444: $C$

445:

446:

447:

448:

448:

450:

451:

452:

453:

454:

465: $C$

456: $C$

457: $\quad$ TMP1X $=-(P I E S T+P H I(I+1, J, K)+P I N S * P H I W S T) * R D X S Q$

458: $\quad T M P 1 Y=-(P I N R T H(I) * P H I(I, J+1, K) * P I S O T H * P H I S T H) * R D Y S Q$

459: $\quad T B P I=$ TMP1X + THP 1Y

480: $C$

461:

482:

463:

464:

485:

468:

487:

488:

489:

470:

471: $C$ 


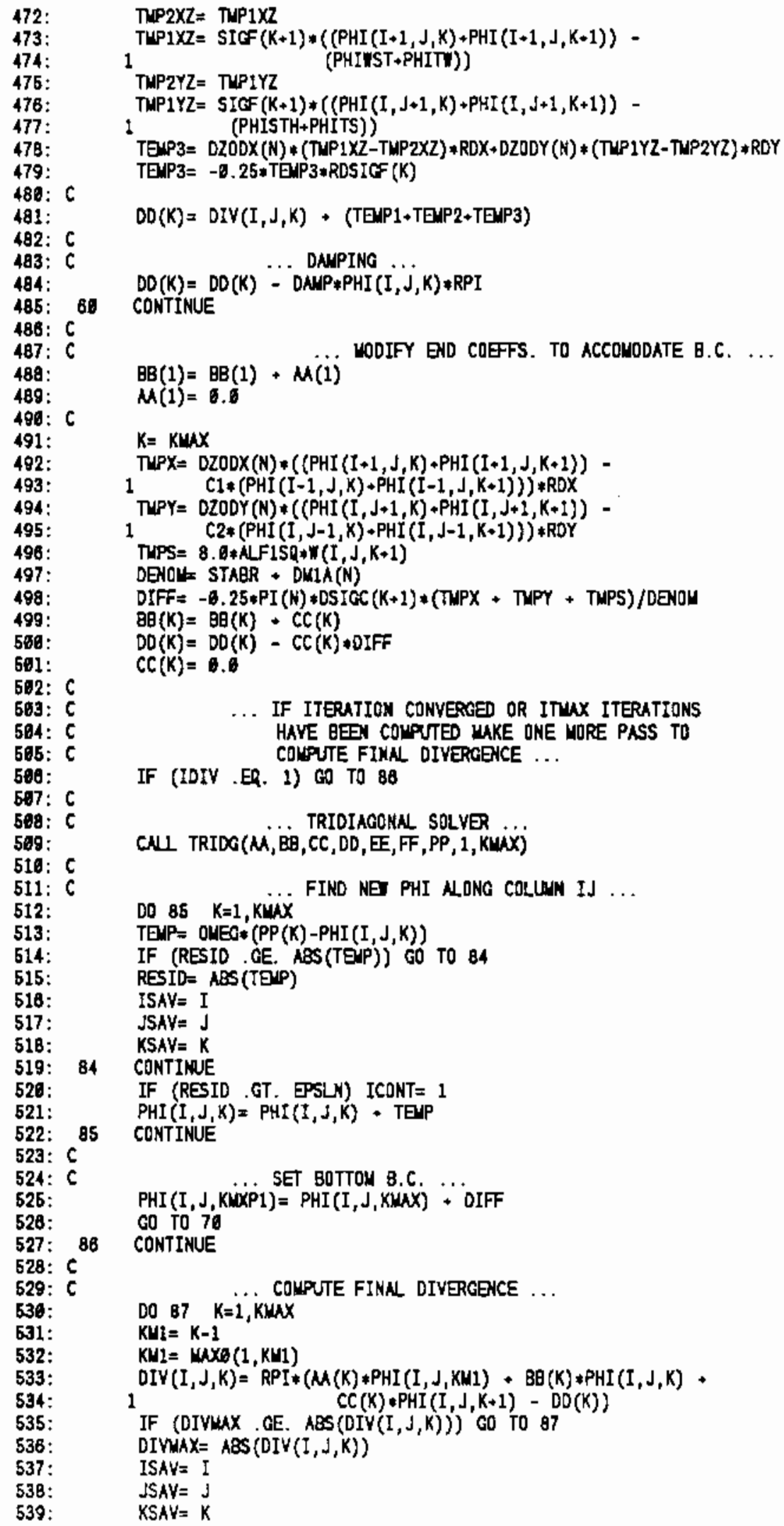




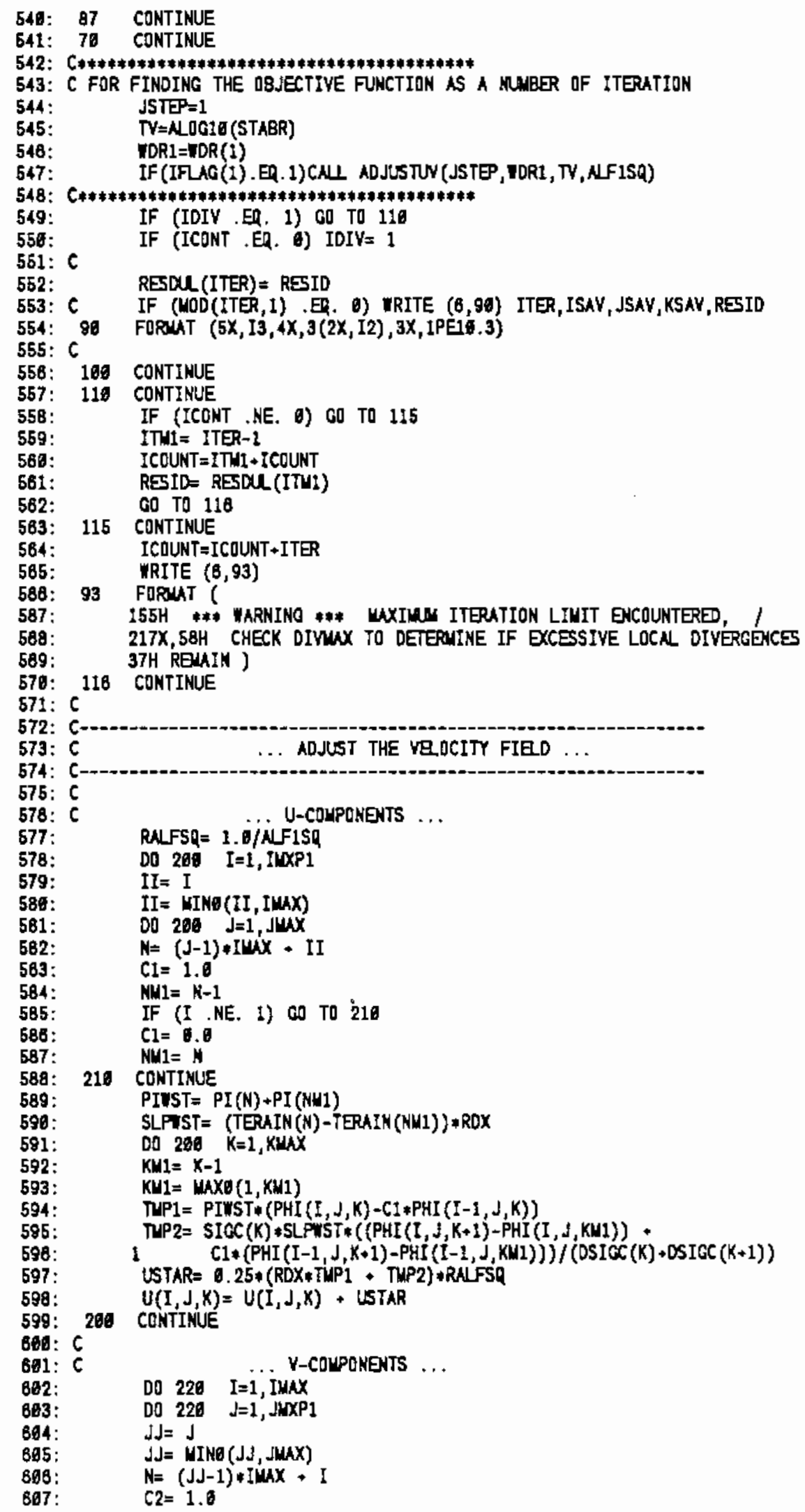

$594:$

TUP1 $=$ PIWST* $(P H I\{I, J, K)-C 1 * P Y I I(I-1, J, K))$

585: $\quad T M P 2=\operatorname{SICC}(K) * \operatorname{SLP} N S T *(\{\operatorname{PHI}(I, J, K+1)-P H I(I, J, K M 1))$.

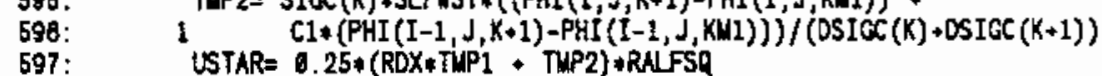

597: USTAR $=0.25 *(R D X * T M P 1$ - TMP2 $) * R A L F S$

598: $\quad U(I, J, X)=U(I, J, X)+$ USTAR

599: 200 CONTINUE

680: $C$

681: $C$

632:

683:

694:

895:

896:

RALFSQ $=1.0 /$ N FISQ

$I I=I$

$I I=I N \theta(I I, I M X)$

od $200 \mathrm{~J}=1 \mathrm{~J}$, $4 x$

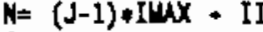

$C 1=1.0$

IF (I . NE. I) 60 TO 210

$\mathrm{Cl}=8 . \mathrm{O}$

NH1= $N$

210 CONTINUE

PINST $=P I(N)+P I(N H 1)$

SLFIST = (TERAIN $(N)-$ TERAIN (NM1) ) $*$ RDX

DO $280 \mathrm{~K}=1, \mathrm{X}$ inx

$K M 1=X-1$

$\mathrm{KH} 1=\operatorname{MNX0}\left(1, \mathrm{KM}_{1}\right)$

D0 $220 \quad I=1$, I IMAX

DO $220 \mathrm{~J}=1, \mathrm{NXP1}$

$\mathrm{JJ}=\mathrm{J}$

$\mathrm{J} J=\operatorname{MINO}(\mathrm{J} J, \mathrm{JMAX})$

$N=(J J-1)+\operatorname{Imax}+I$

$\mathrm{C} 2=1.6$ 


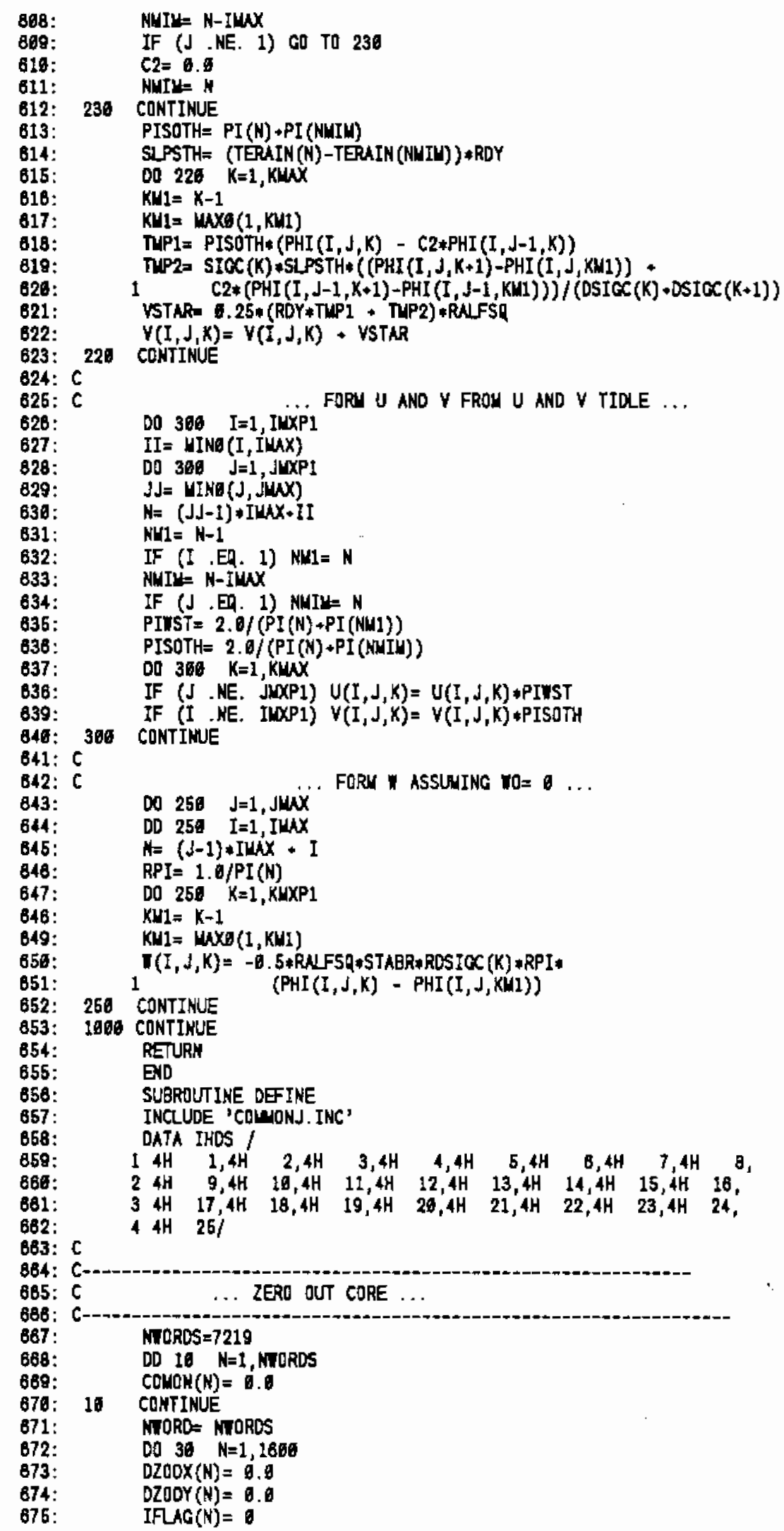

634:

635:

638:

637:

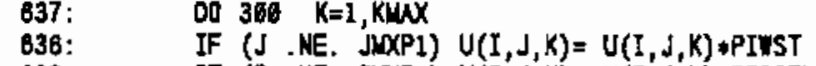

839: $\quad$ IF (I . NE. ILXP1) $V(I, J, K)=V(I, J, K) * P I S O T H$

648: 306 CONTINUE

641: $C$

B42: $C$

643:

644:

645:

846:

647:

646:

649:

650:

651:

652:

654:

$655:$

658:

657:

858 :

868:

681:

682:

B63: $C$

884: $C$

685: $C$

688:

687:

668:

689:

670:

671:

672:

873:

676:

$00300 \quad I=1, I$ IXXP1 FORU U ANO $\checkmark$ FROM U AND $\vee$ TIDLE ...

$I I=\operatorname{IINO}(I, I \operatorname{MAX})$

DO $300 \mathrm{~J}=1, \mathrm{~J} \times \mathrm{XPI}$

$j J=\operatorname{Ming}(J, J \omega x)$

$N=(J J-I) * I M A X+I I$

$N L 1=N-1$

IF (I .ER. 1) $N M 1=N$

$N M I N=N-I M N$

IF (J.E. 1) NMIL = N

PIWST $=2.0 /(P I(N)+P I(N M 1))$

PISOTH $=2.0 /(\mathrm{PI}(\mathrm{N})+\mathrm{PI}($ NNIH $))$

c

Do $250 \quad \mathrm{~J}=1, \mathrm{~J} w \mathrm{KX}$. FORM ASSUMING $\mathrm{rO}=0 \ldots$

DD 259 I=1, ILAX

$N=(J-1) * I L A X+I$

$\mathrm{RPI}=1.0 / \mathrm{PI}(\mathrm{N})$

DO $250 \mathrm{~K}=1$, KUXP1

$\mathrm{K} H 1=\mathrm{K}-1$

$K M 1=\operatorname{MXO}\left(1, K H_{1}\right)$

$\Pi(I, d, K)=-D .5 * R A N F 5 Q * S T A B R * R Q S I C C(K) * R P I *$

250

CONTINUE

2000 CONTINUE

RETURN

END

SUBROUTINE DEINE

INCLUDE 'COLMONJ. INC'

DATA IHOS /

$14 \mathrm{H} \quad 1,4 \mathrm{H} \quad 2,4 \mathrm{H} \quad 3,4 \mathrm{H} \quad 4,4 \mathrm{H} \quad 5,4 \mathrm{H} \quad \mathrm{B}, 4 \mathrm{H} \quad 7,4 \mathrm{H} \quad \mathrm{B}$,

2 4H $9,4 \mathrm{H} \quad 19,4 \mathrm{H} \quad 11,4 \mathrm{H} \quad 12,4 \mathrm{H} \quad 13,4 \mathrm{H} \quad 14,4 \mathrm{H} \quad 15,4 \mathrm{H} \quad 16$,

3 4H 17,4H 18,4H 19,4H 29,4H 21,4H 22,4H 23,4H 24,

$44 \mathrm{H} \mathrm{25/}$

$(\operatorname{PHI}(I, J, K)-\operatorname{PHI}(I, J, K(M I))$

.. ZERO OUT CORE ...

NTOROS $=7219$

DD $10 N=1$, MTORDS

10 CONTINUE

MTORO $=$ MTOROS

Dd $30 N=1,1660$

$\operatorname{DZOOX}(\boldsymbol{N})=0.0$

$\operatorname{DZOOY}(N)=0.0$

$\operatorname{IFAG}(N)=0$ 


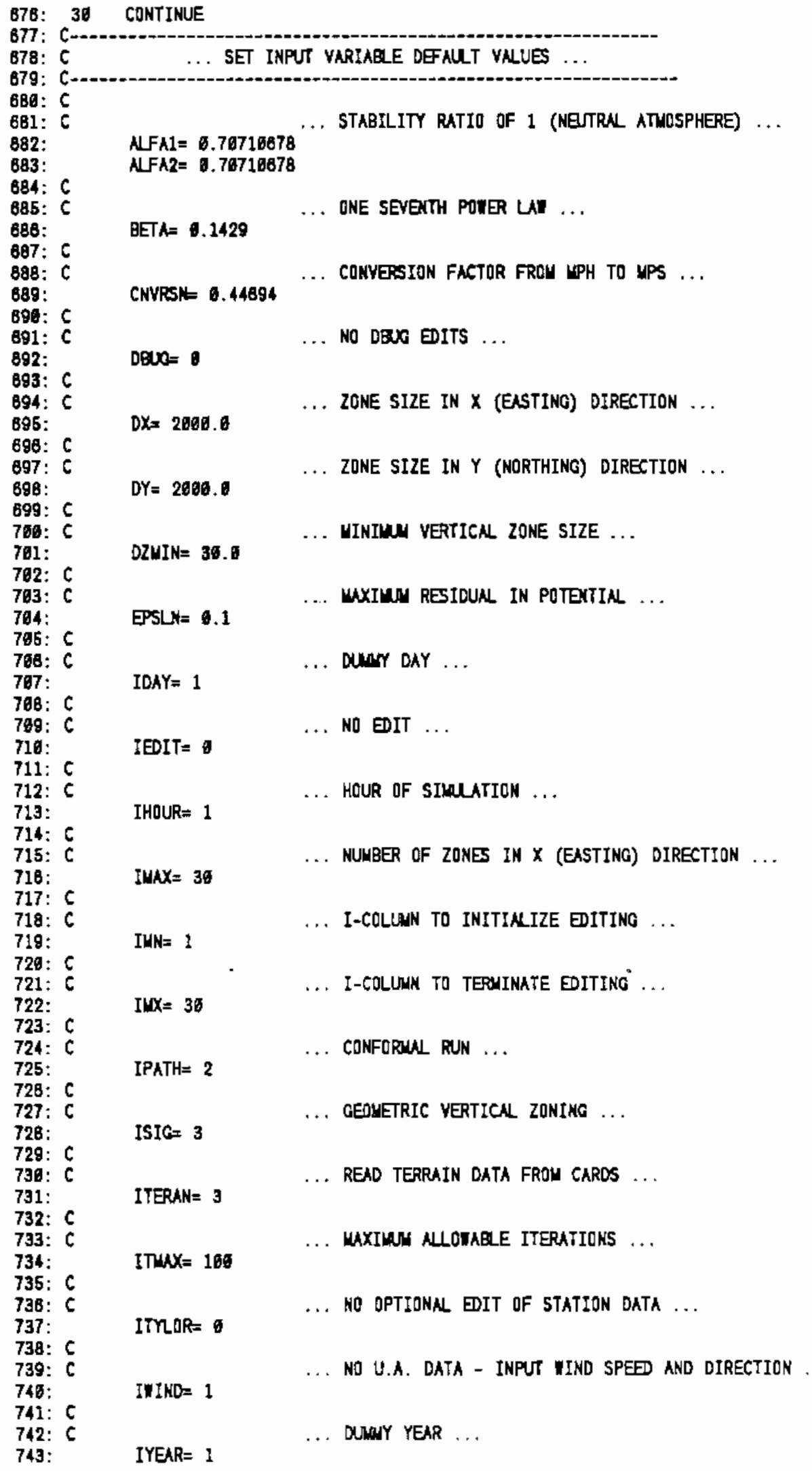




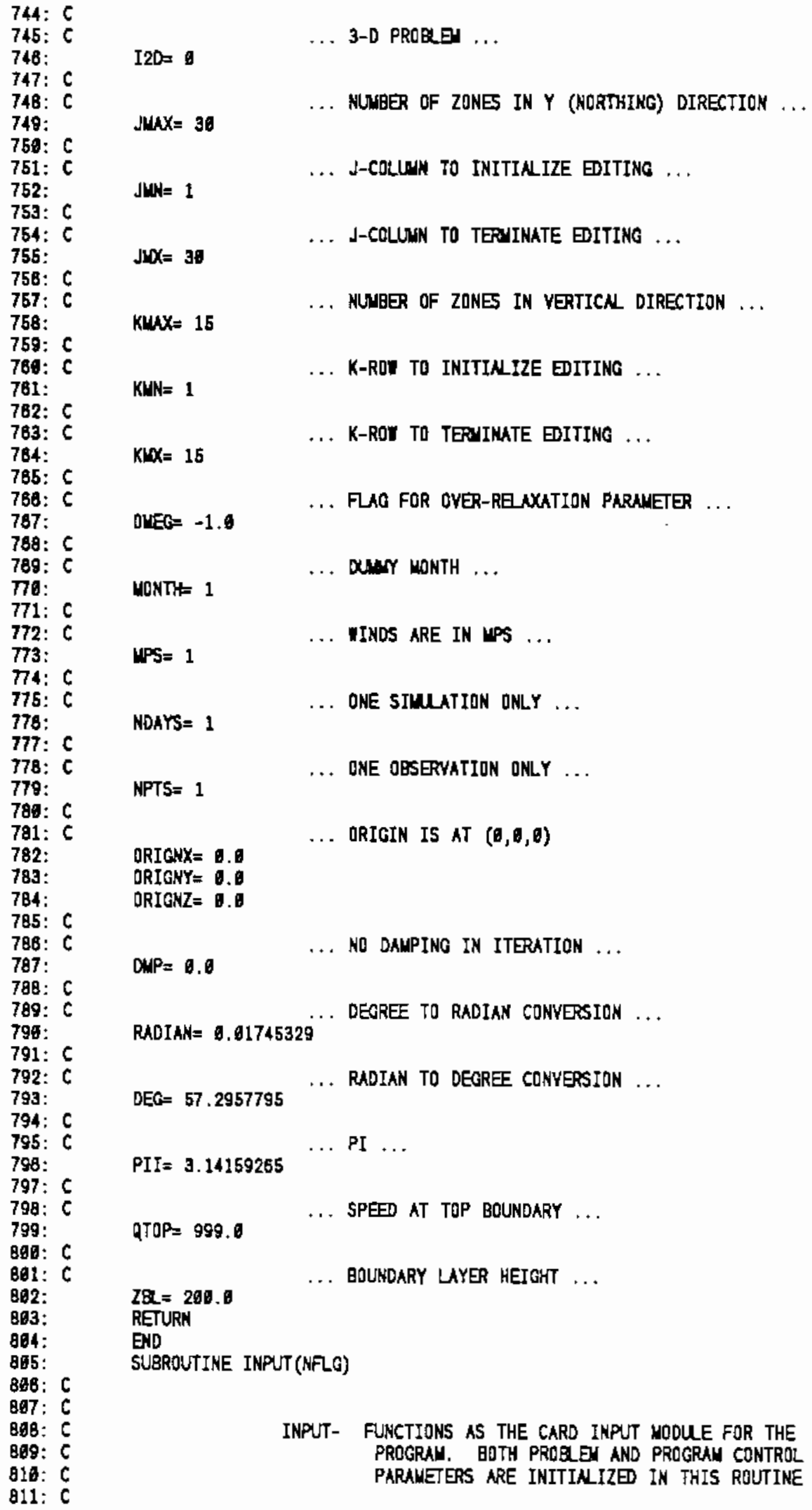




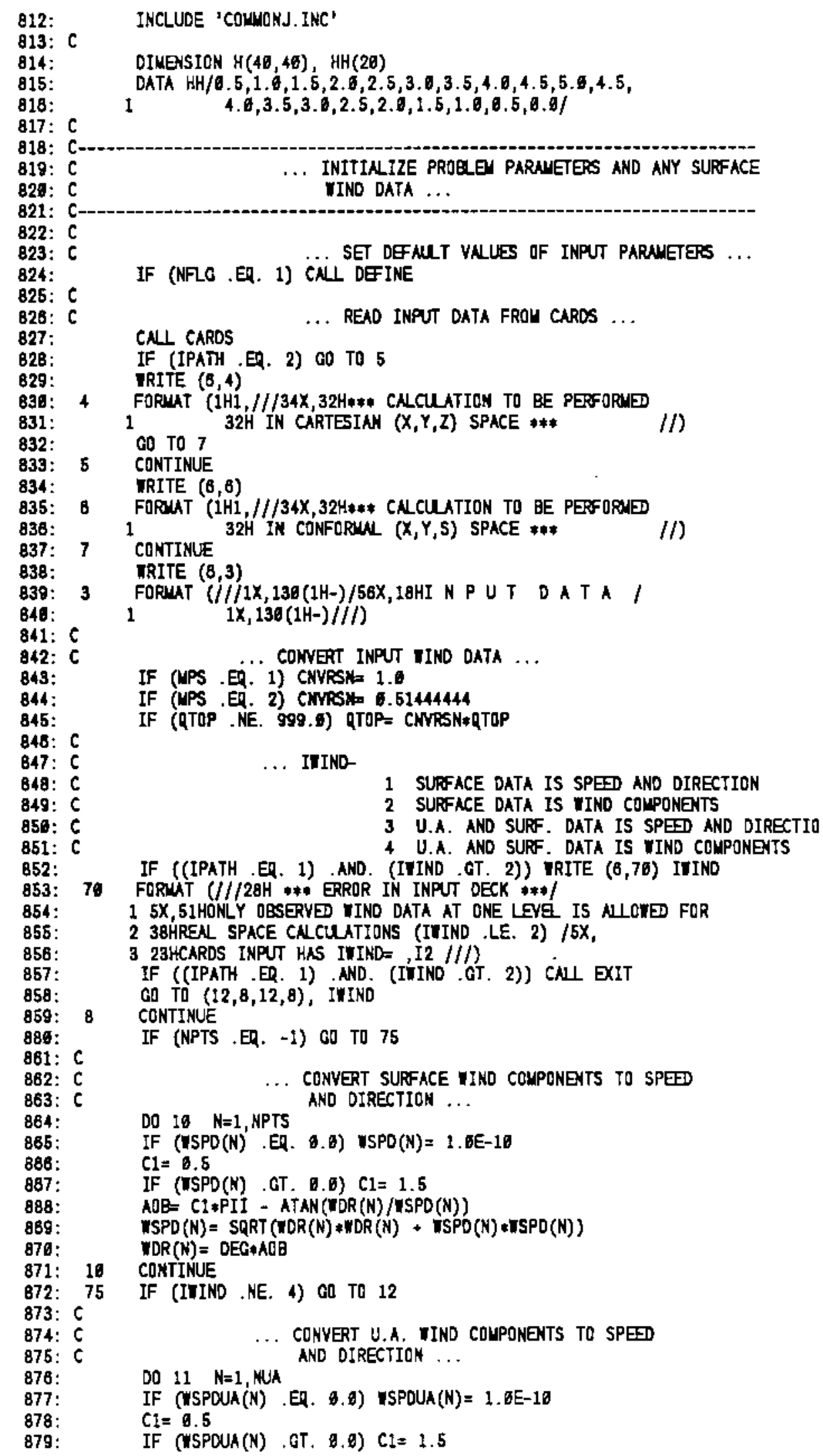

B28:

829:

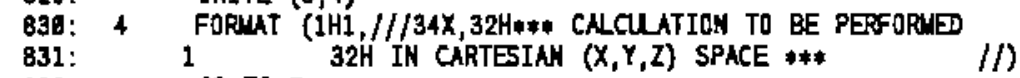

832: $\quad$ CO TO 7

833: 5 CONTINUE

834: TRITE $(6,8)$

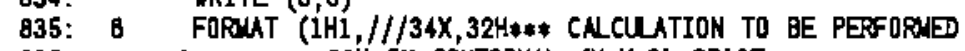

836: 1 32H IN CONFORUL $(x, y, s)$ SPACE *\#*

837: 7 CONTINUE

838: TRITE $(8,3)$

838: 3 FORUA $(/ / / 1 X, 138(1 H-) / 56 X$, 18HI N P UT DATA $/$

840: 1 1 $1,130(1 H-) / / /)$

841: $C$

942: $C$

843:

845:

848: $C$

B47: $C$

B48: C

849: $C$

850: $C$

851: C

852:

853:

854:

855:

856 :

$857:$

858:

859:

886:

861: C

862: C

863: $C$

864:

885:

888:

887:

888:

869:

870:

871 .

872: 75

873: $C$

874: C

875: C

878:

877:

878:

.. CONERT INPUT IIND DATA ...

IF (MPS .EQ. 1) CNYRSW 1.0

IF (MPS .EA. 2) CNYRSH 6.61444444

IF (QTOP .NE. 999.5) QTOP= CNNBN $\approx$ QTOP

... ITIND-

1 SUPFACE DATA IS SPEED AND DIRECTION

2 SURFACE DATA IS IINO COMPONENTS

3 U.A. AND SURF. DATA IS SPEDD AND DIRECTIO

4 U.A. AND SURF. DATA IS IIND COMPONENTS

IF ((IPATH .EA. 1) .AND. (IIIND .GT. 2)) VRITE $(6,76)$ ITIND

70 FORUAT $U / / 28 \mathrm{H}$ *** ERROR IN INPUT OECK $* * \neq 1$

1 5X,51HONLY OBSERVD IND DATA AT ONE LEYA IS AШONED FOR

2 3BHREAL SPACE CNLCUATIONS (ITIND .LE. 2) /5X,

3 23HCARDS INPUT HAS ININD=, I2 $/ / / 7$

IF ((IPATH .ER. 1) .ND. (IIINO .GT. 2)) CAL EXIT

GD TO $(12,8,12,8)$, ININD

8 CONTINUE

IF (NPTS .EQ. -1) GO TO 75

DO $16 \mathrm{~N}=1$, NPTS

.. CONYERT SURFACE WIND COMPONEATS TO SPEED

IF (USPD(N) .EA. B. 1 ) $\mathrm{NSPO}(\mathrm{N})=1.6 \mathrm{E}-10$

$C 1=6.8$

IF (ISPD(N) .GT. G. E) $\mathrm{Cl}=1.5$

$A O B=C 1 * P I I-A T A N(W D R(N) / M S P D(N))$

WSPD $(N)=\operatorname{SQRT}($ WDR $(N) * W D R(N)+\mathbb{N S P D}(N) * T S P D(N))$

WDR $(N)=$ DEG AAOB

CONTINUE

IF (ITIND . NE. 4) GO TO 12

.. CONYERT U.A. IND COUPONENTS TO SPED

DO $11 \quad N=1$, NUA

IF (WSPOUA $(N)$.ER. 0.0$)$ ISPOUA $(N)=1.6 E-10$

$\mathrm{Cl}=0.5$

IF (WSPOUA(N), GT, $C .9) \quad C I=1.5$ 


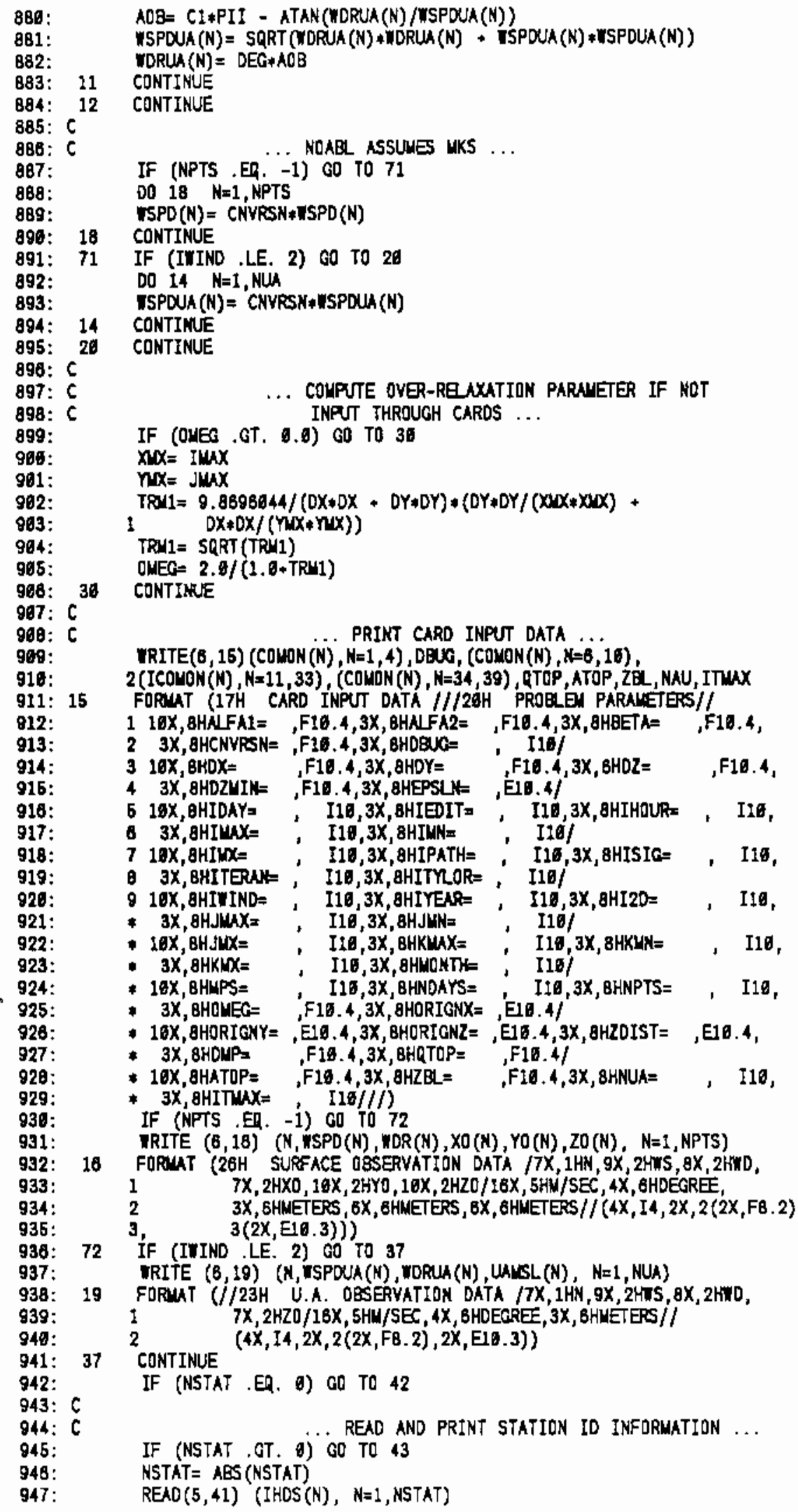




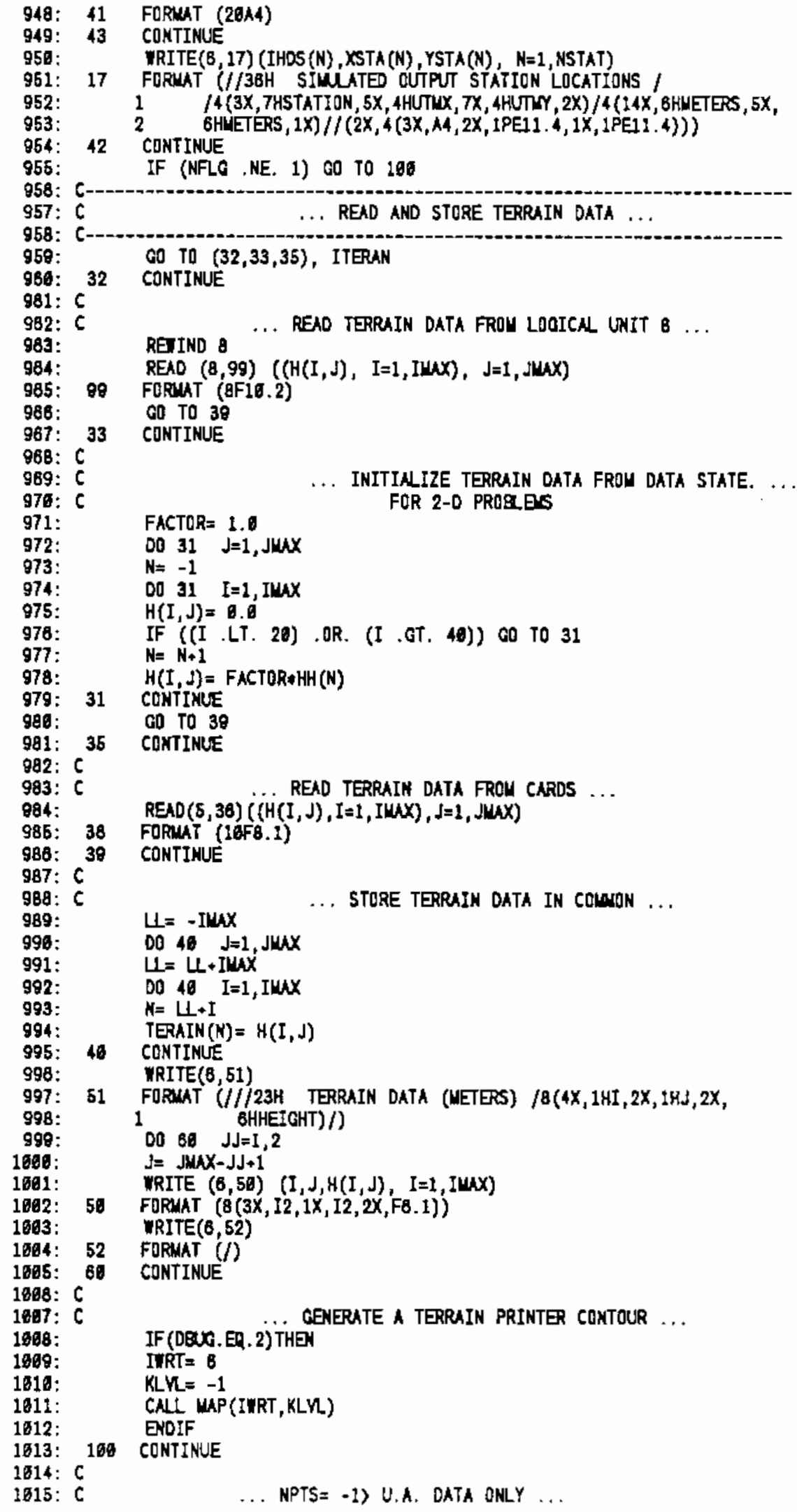

992:

993:

994: $\operatorname{TERAIN}(\mathrm{N})=\mathrm{H}(\mathrm{I}, \mathrm{J})$

995: 46 CONTINUE

998: $\quad$ WRITE $(8,51)$

997: 51 FORMT (///23H TERRAIN DATA (METERS) /8(4X,1HI, 2X,1HJ,2X, 


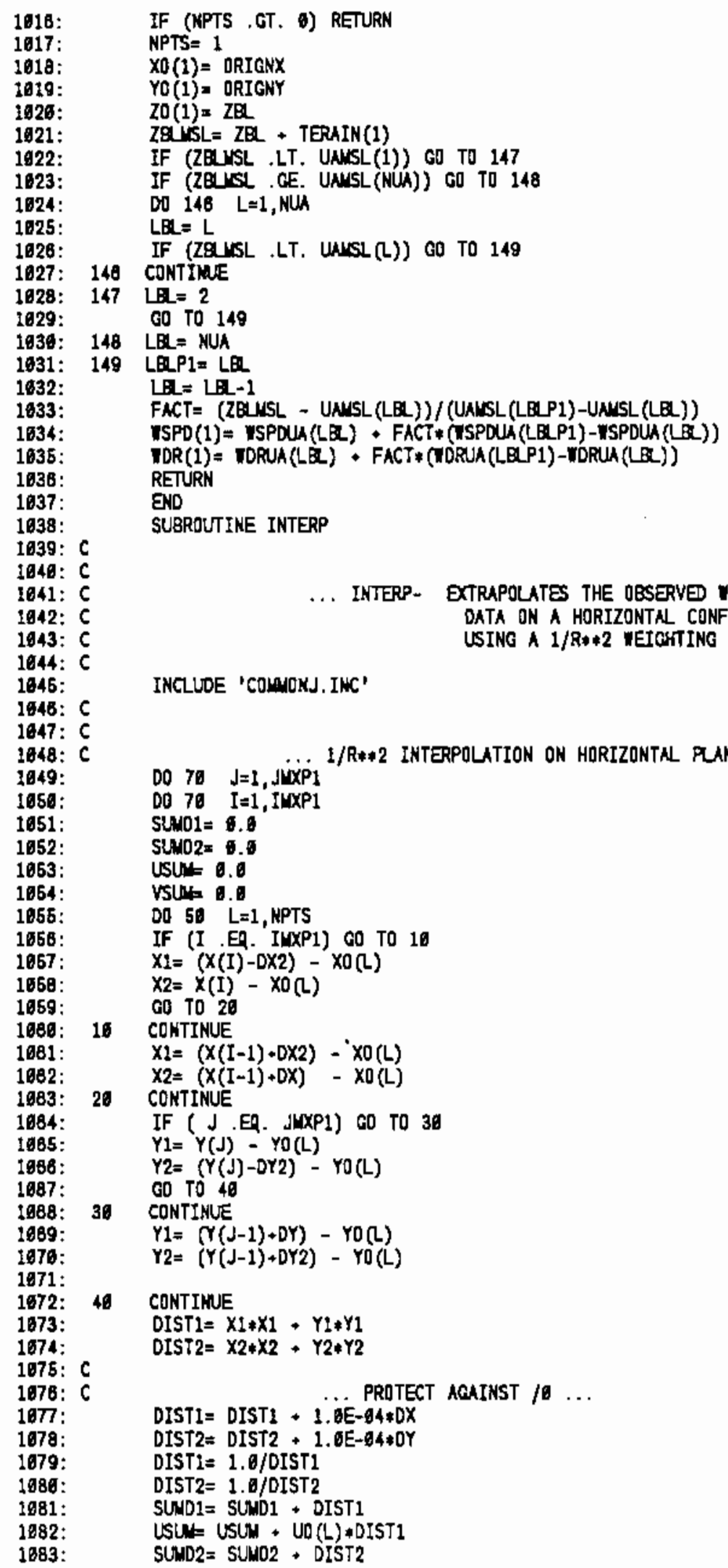




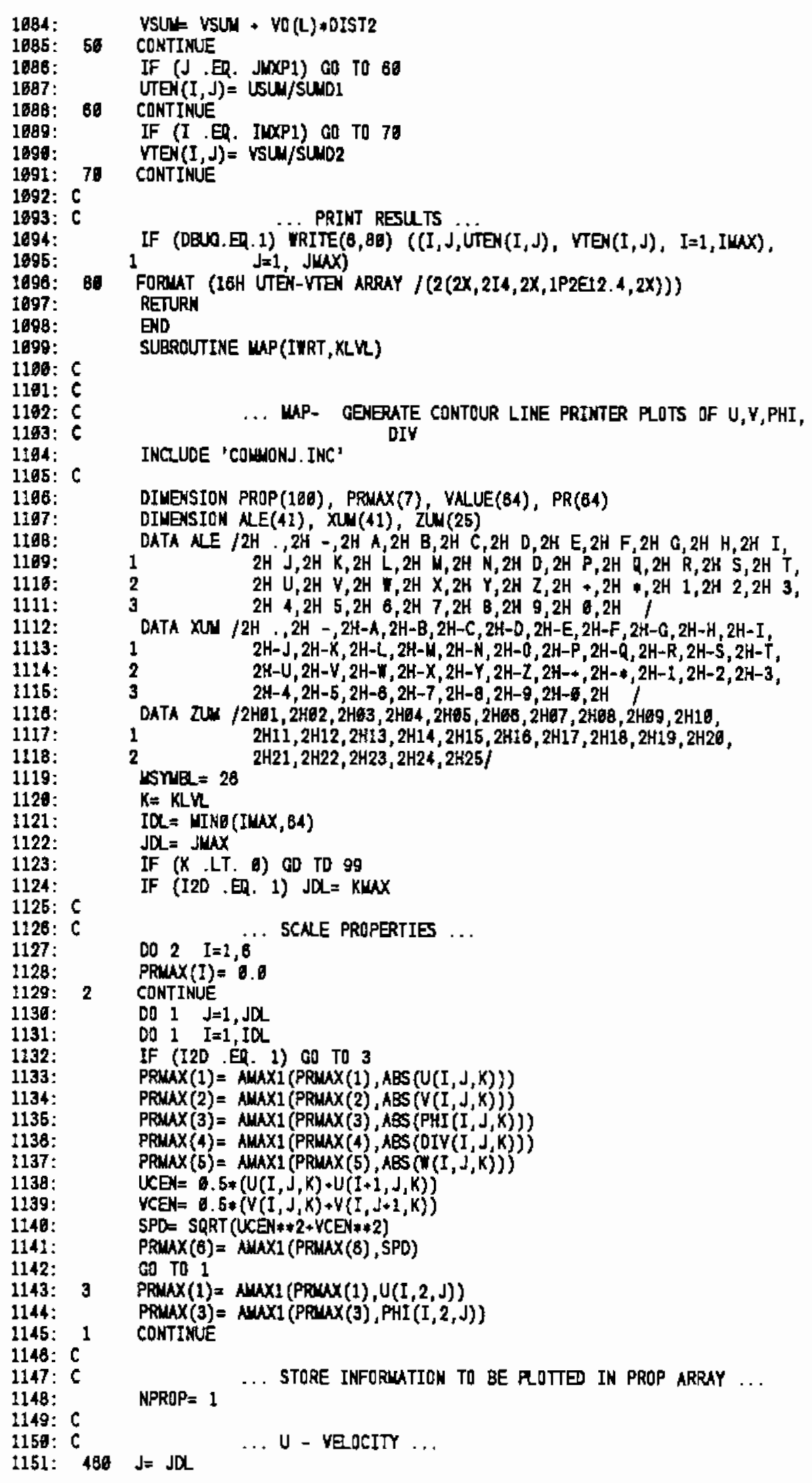

1111:

1112:

1113:

1114:

1115:

1110:

1117:

1118:

1119:

1120:

1121:

1122:

1123 :

1124:

1125: $C$

1128: $C$

1127:

1128:

1129:

1136:

1131:

1132:

1133:

1134:

1135:

1138:

1137:

1138:

1139:

1148:

1141:

1142:

1143: $3 \quad \operatorname{PRNAX}(1)=\operatorname{MNAX}(\operatorname{PRMX}(1), U(I, 2, J))$

1144: $\quad \operatorname{PRMAX}(3)=\operatorname{ANAX1}(\operatorname{PPINX}(3), \operatorname{PHI}(I, 2, J))$

1148: C

1147: $\mathrm{C}$

1148:

1149: C

1150: $C$

... MAP- GENERATE CONTOUR LINE PRINTER PLOTS OF U,Y,PHI, INCZUDE 'COMONJ. INC' 


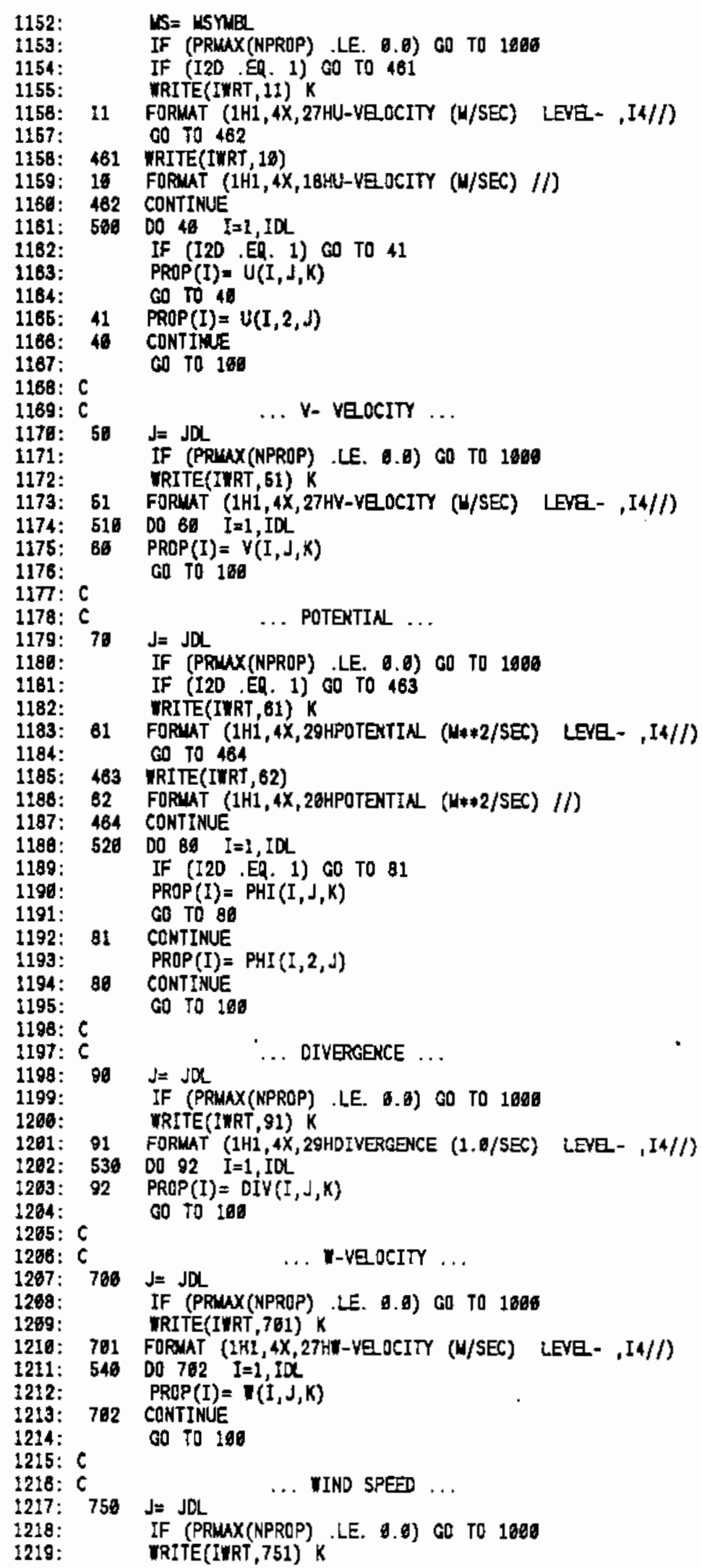




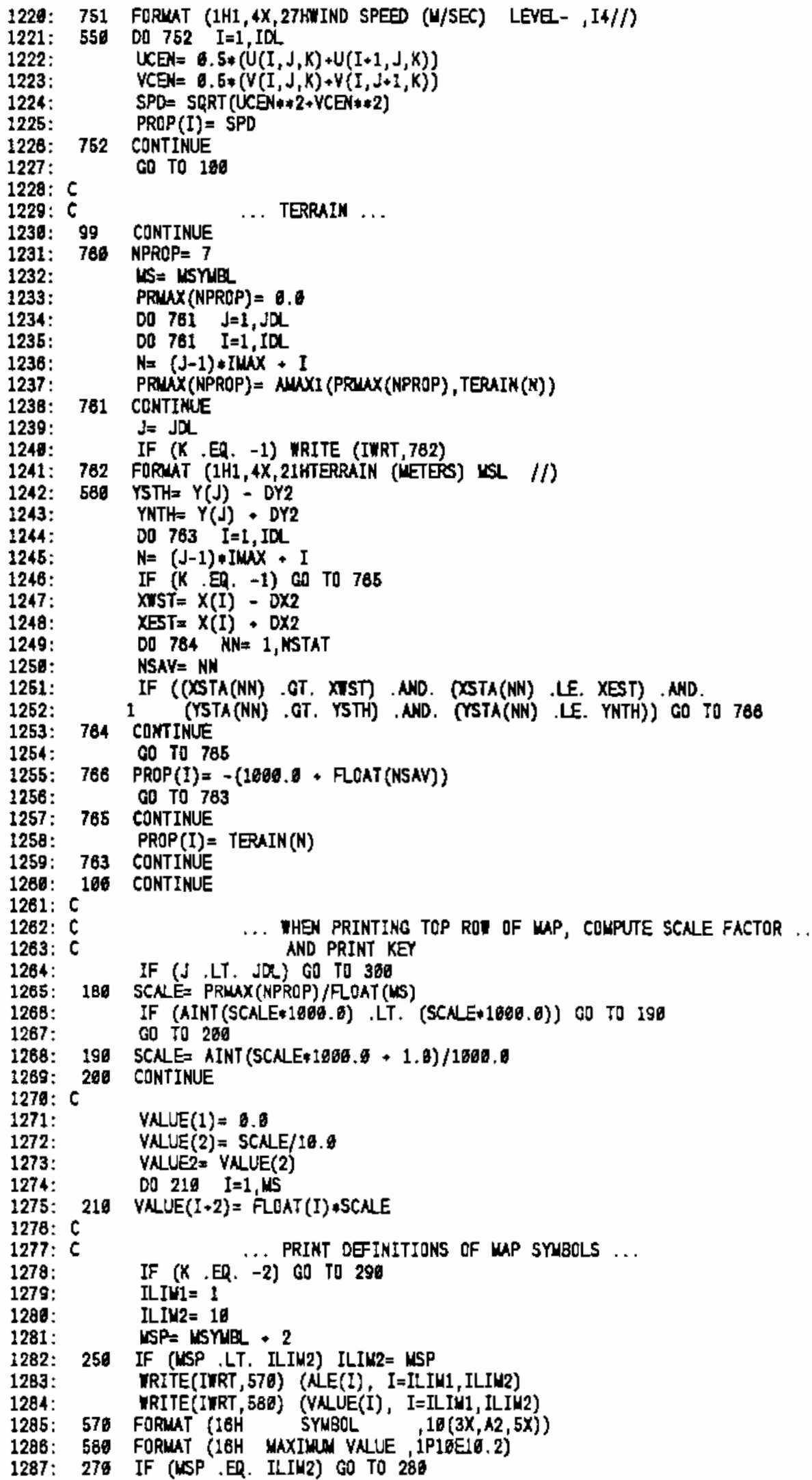




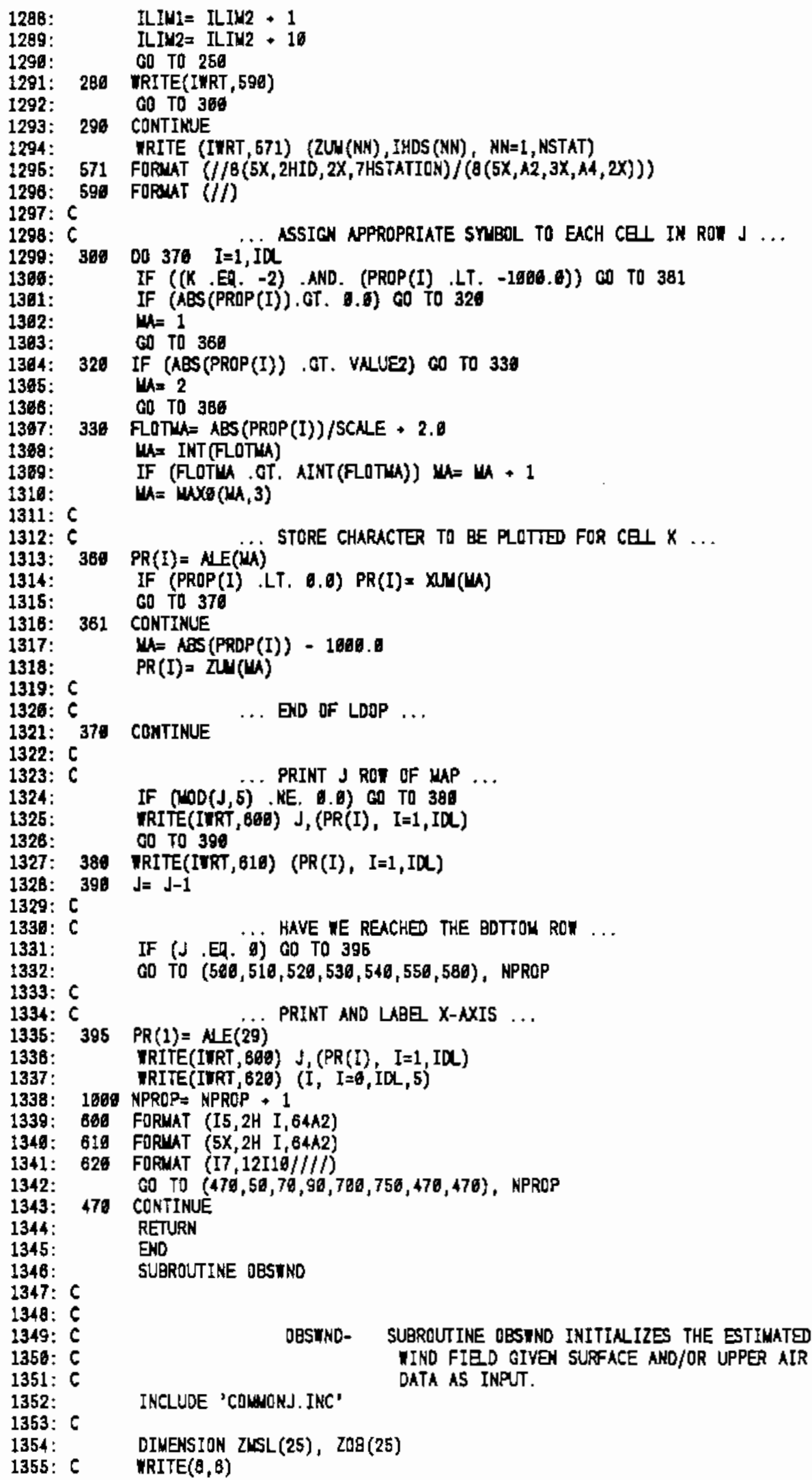




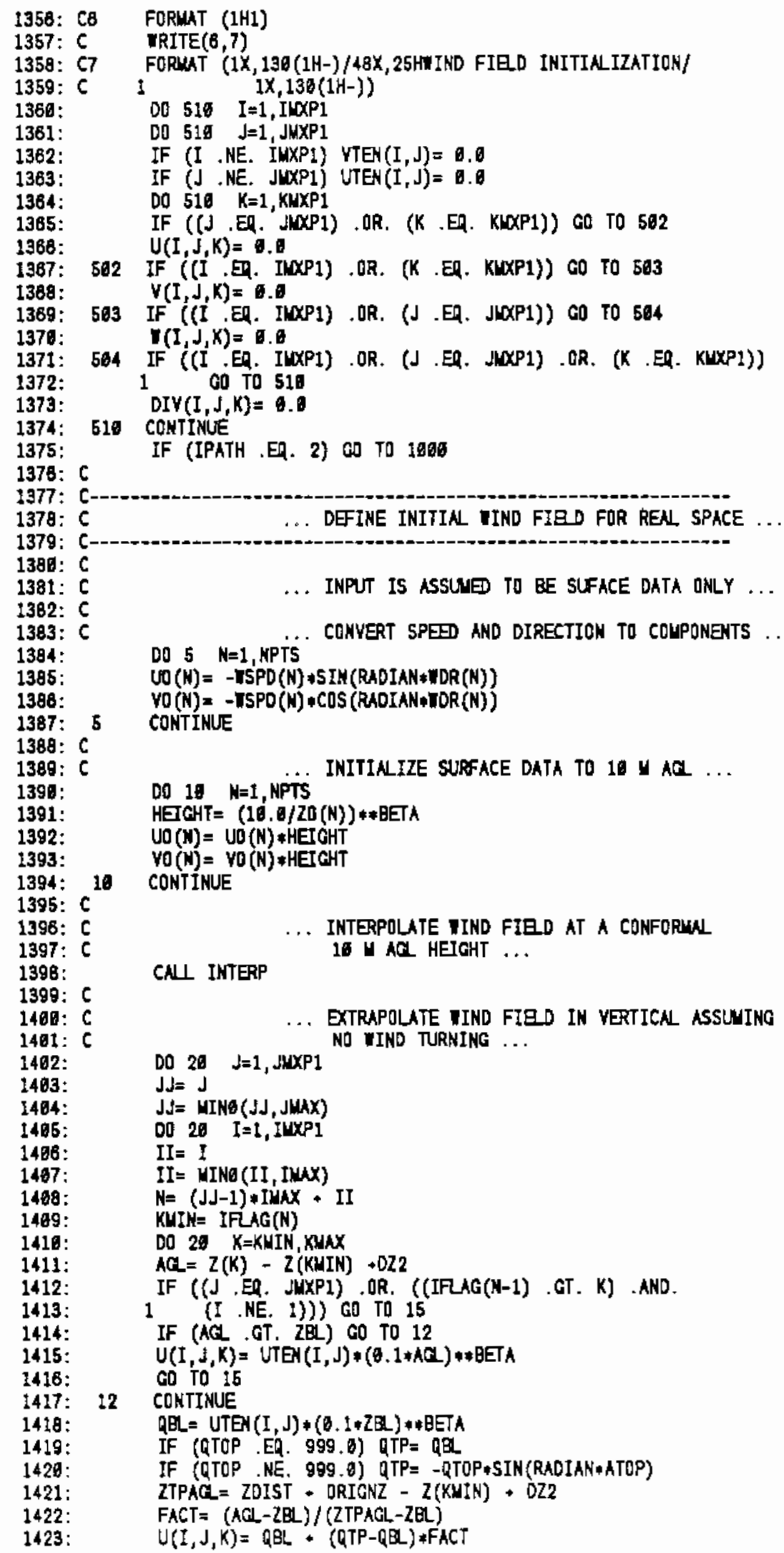




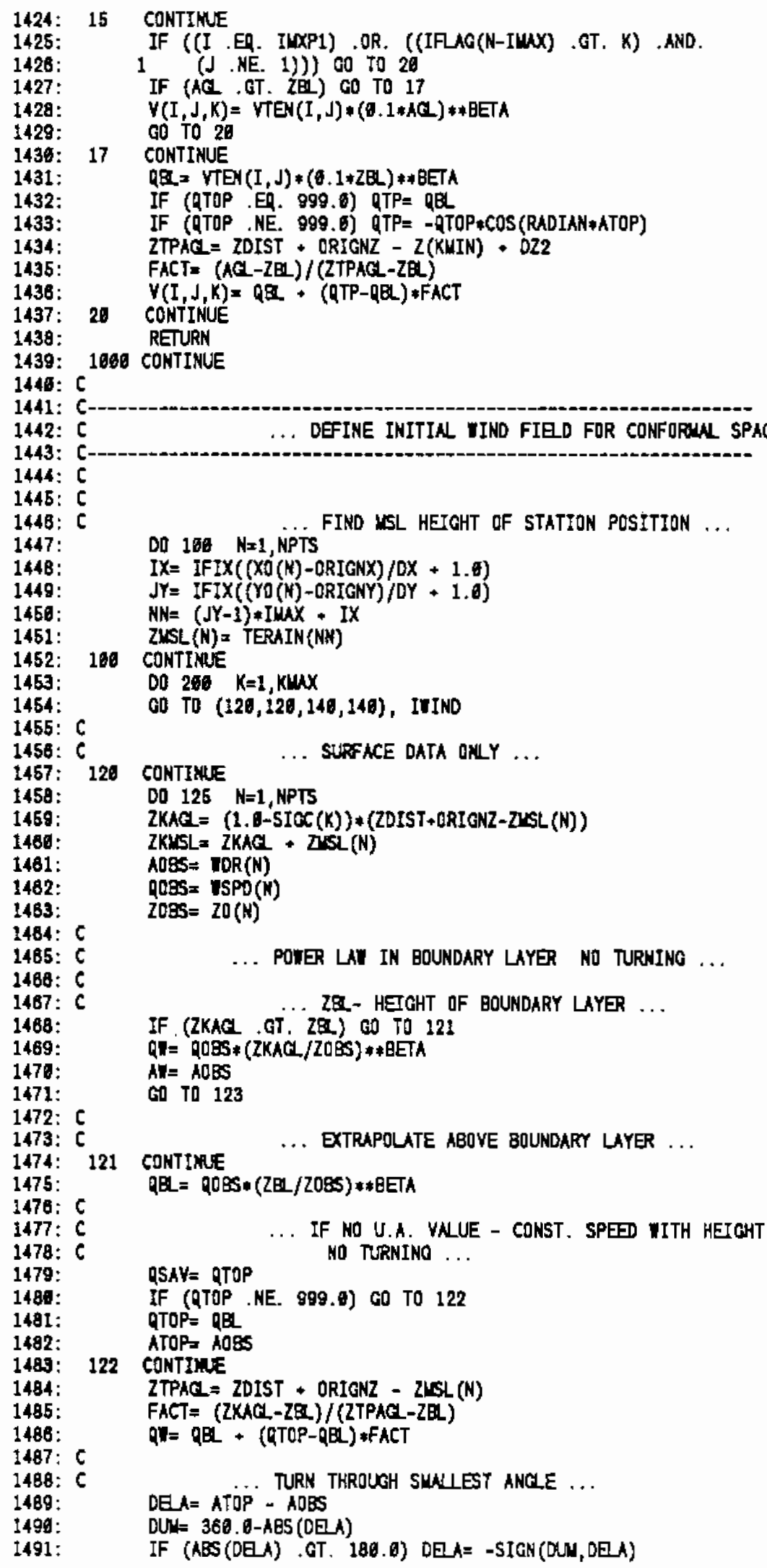




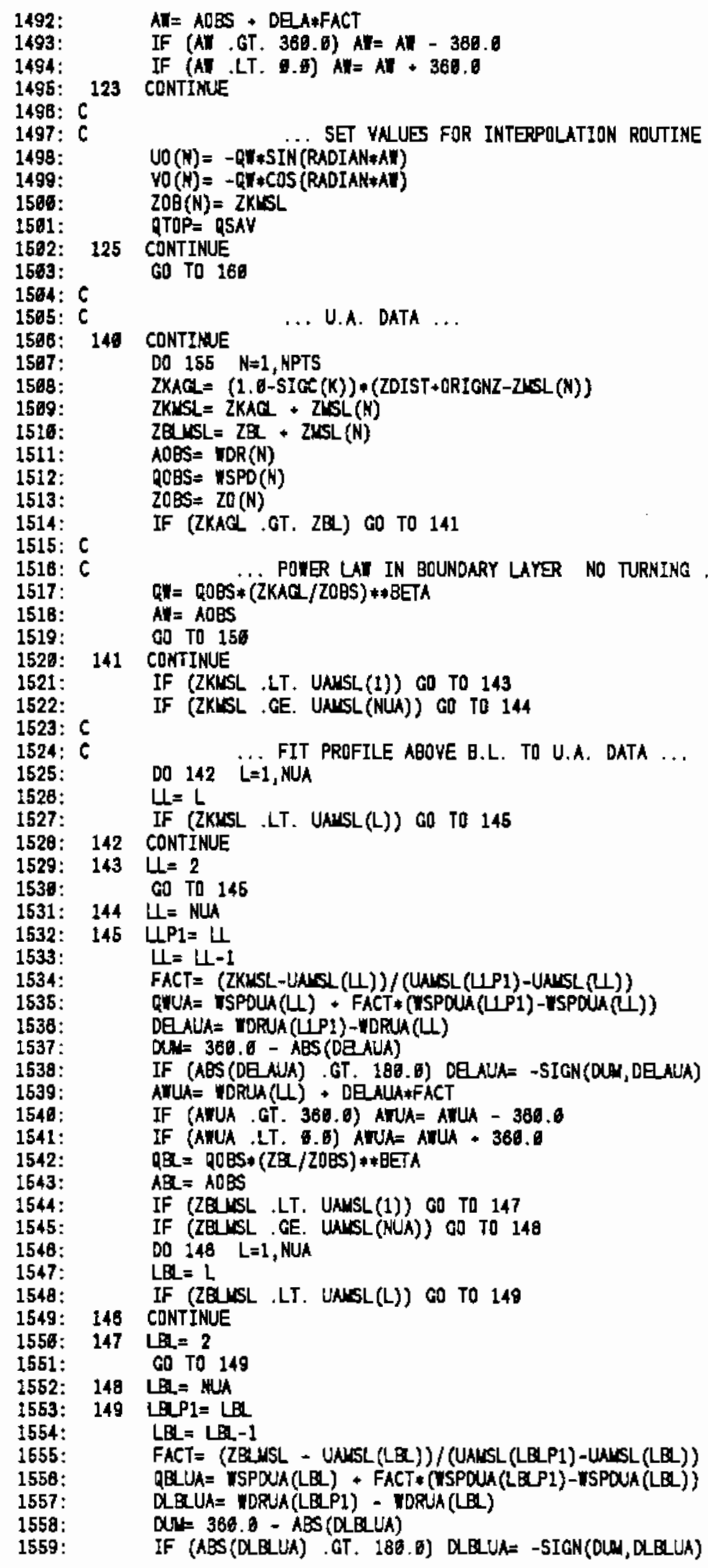




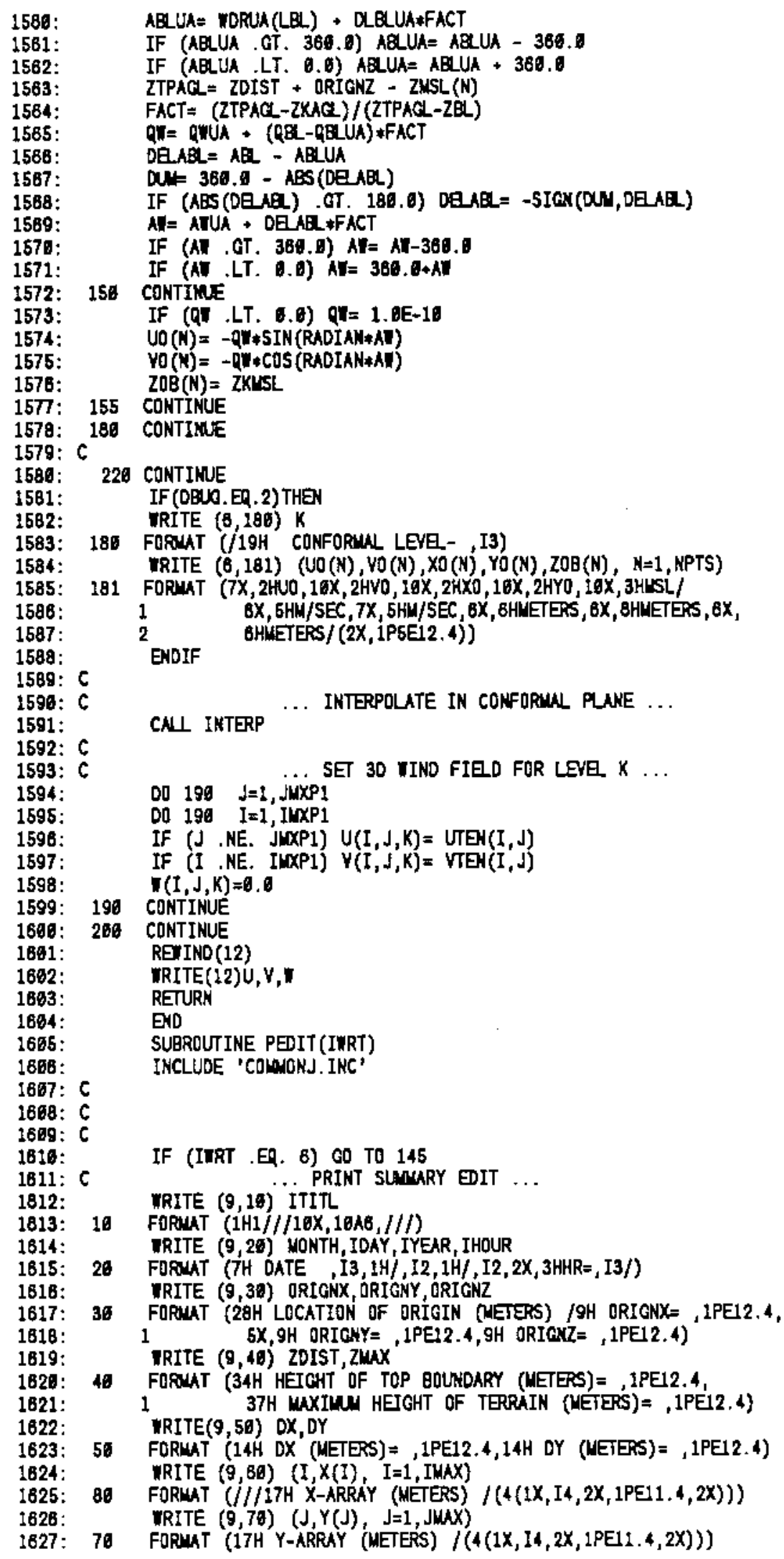




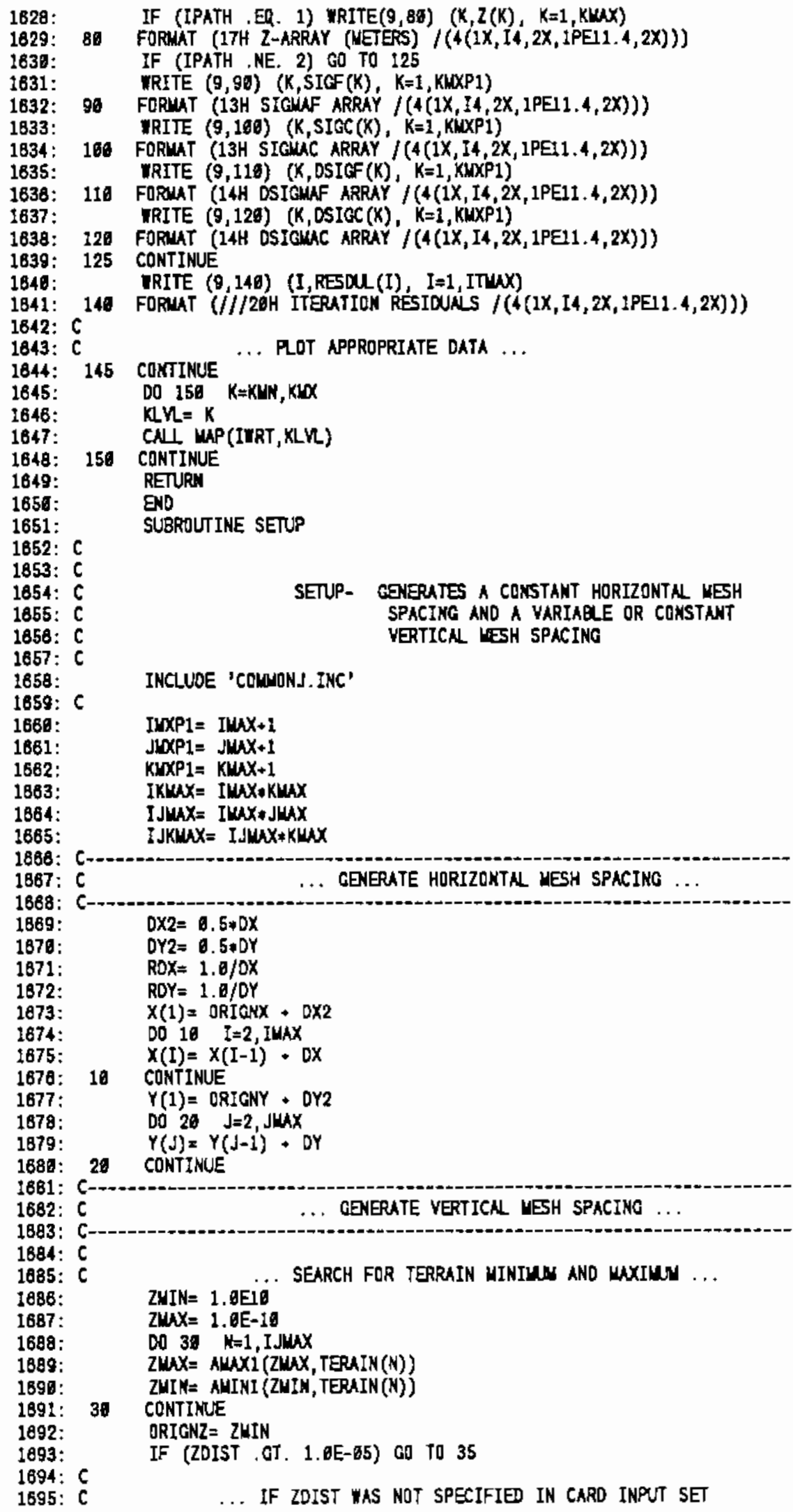




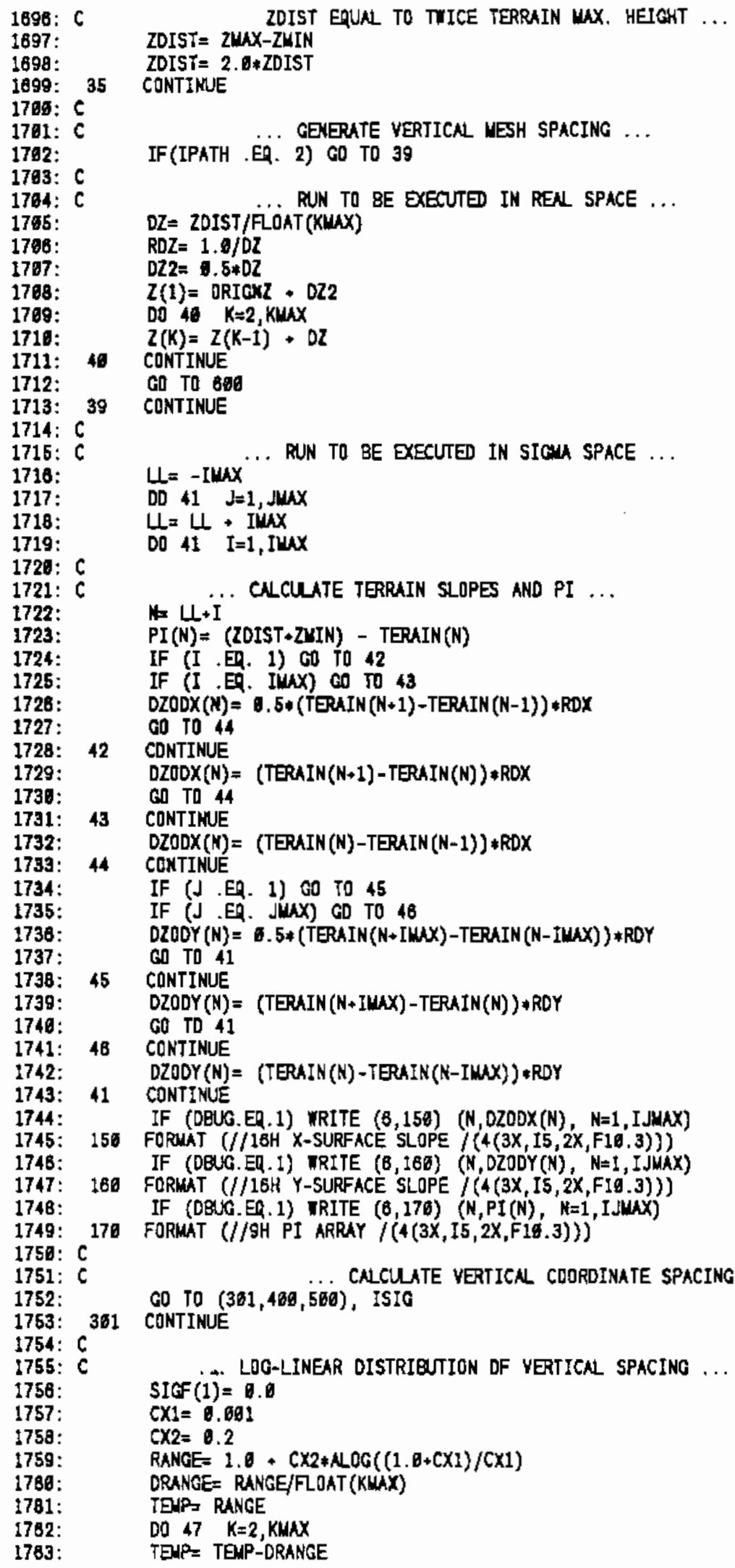




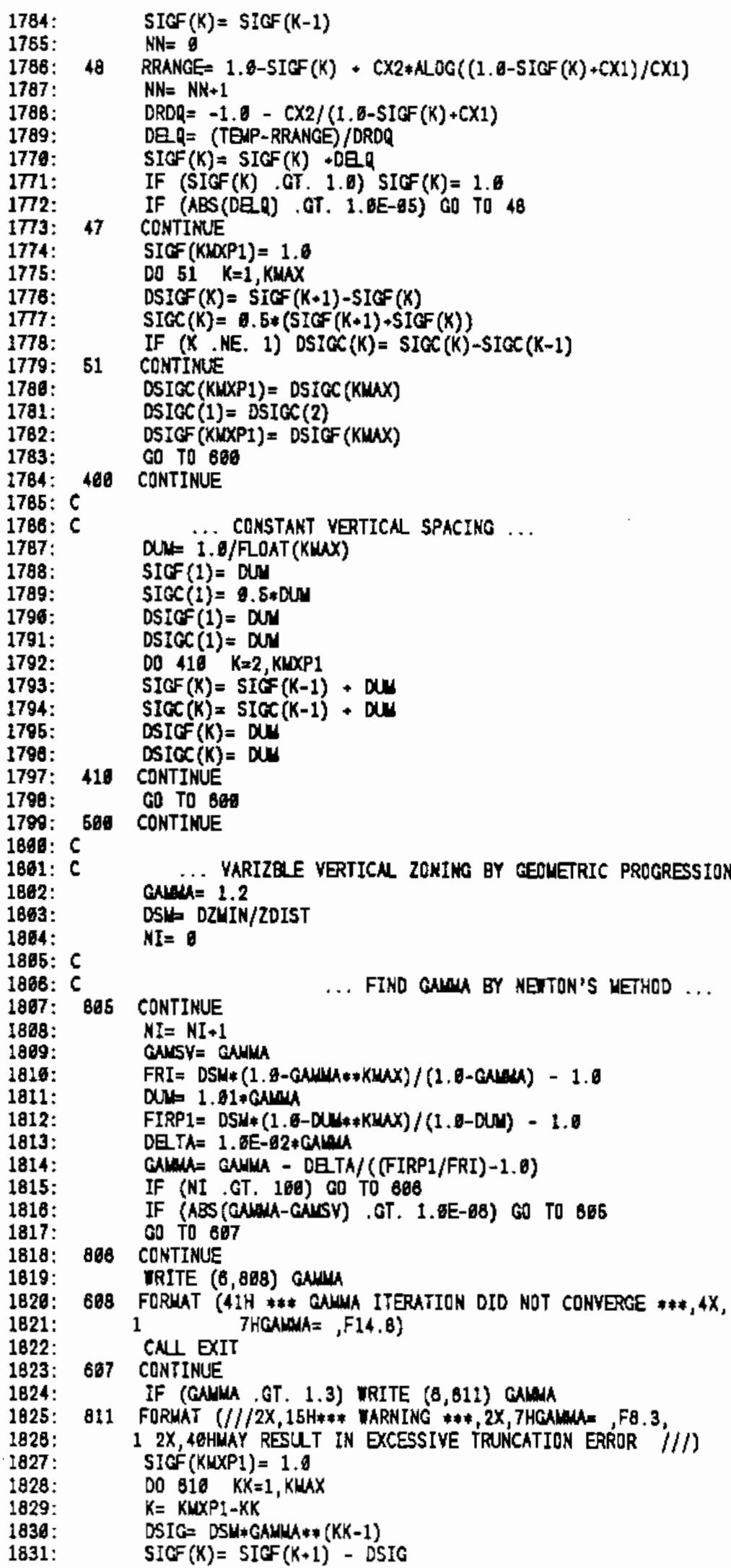




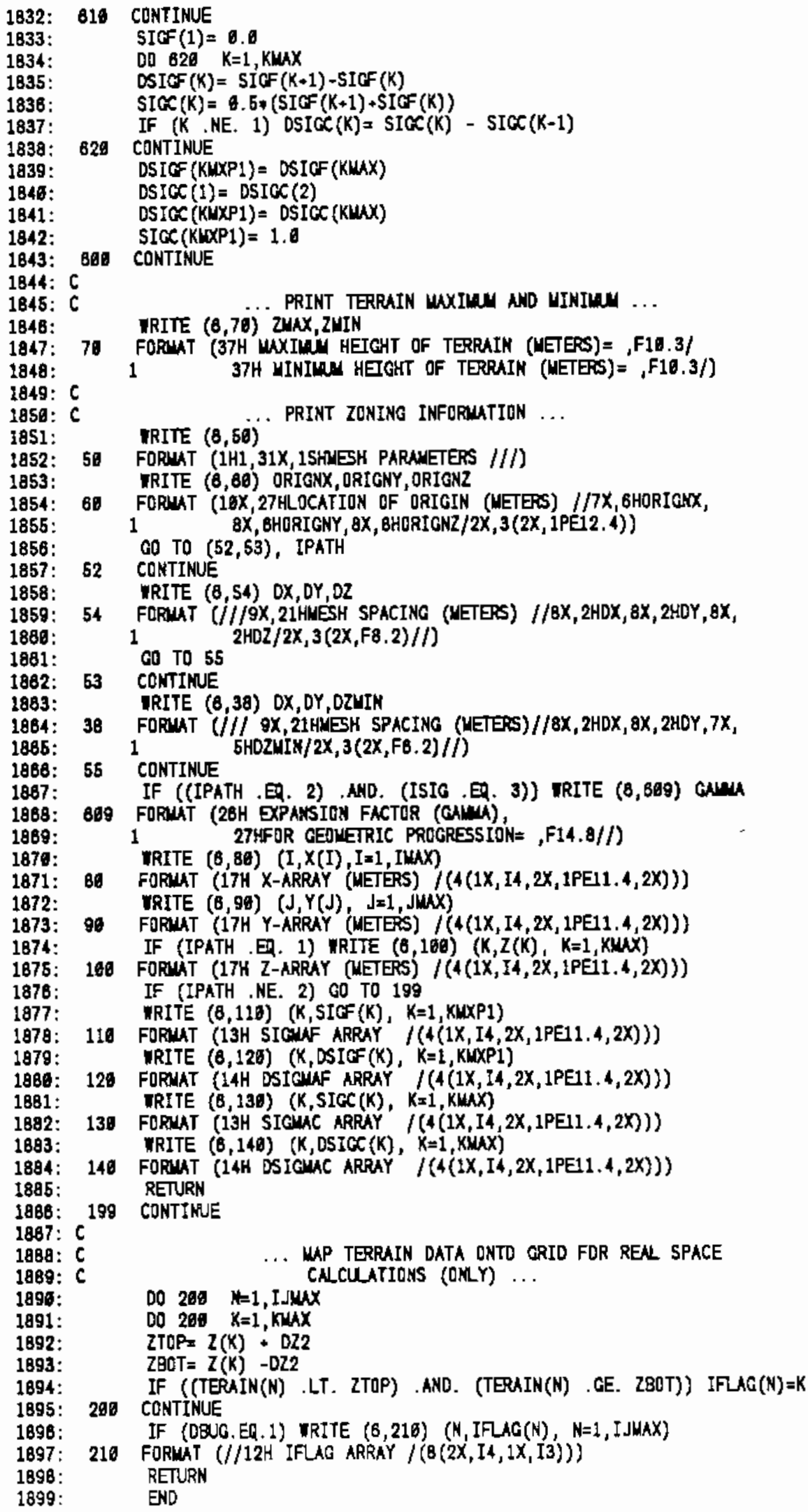




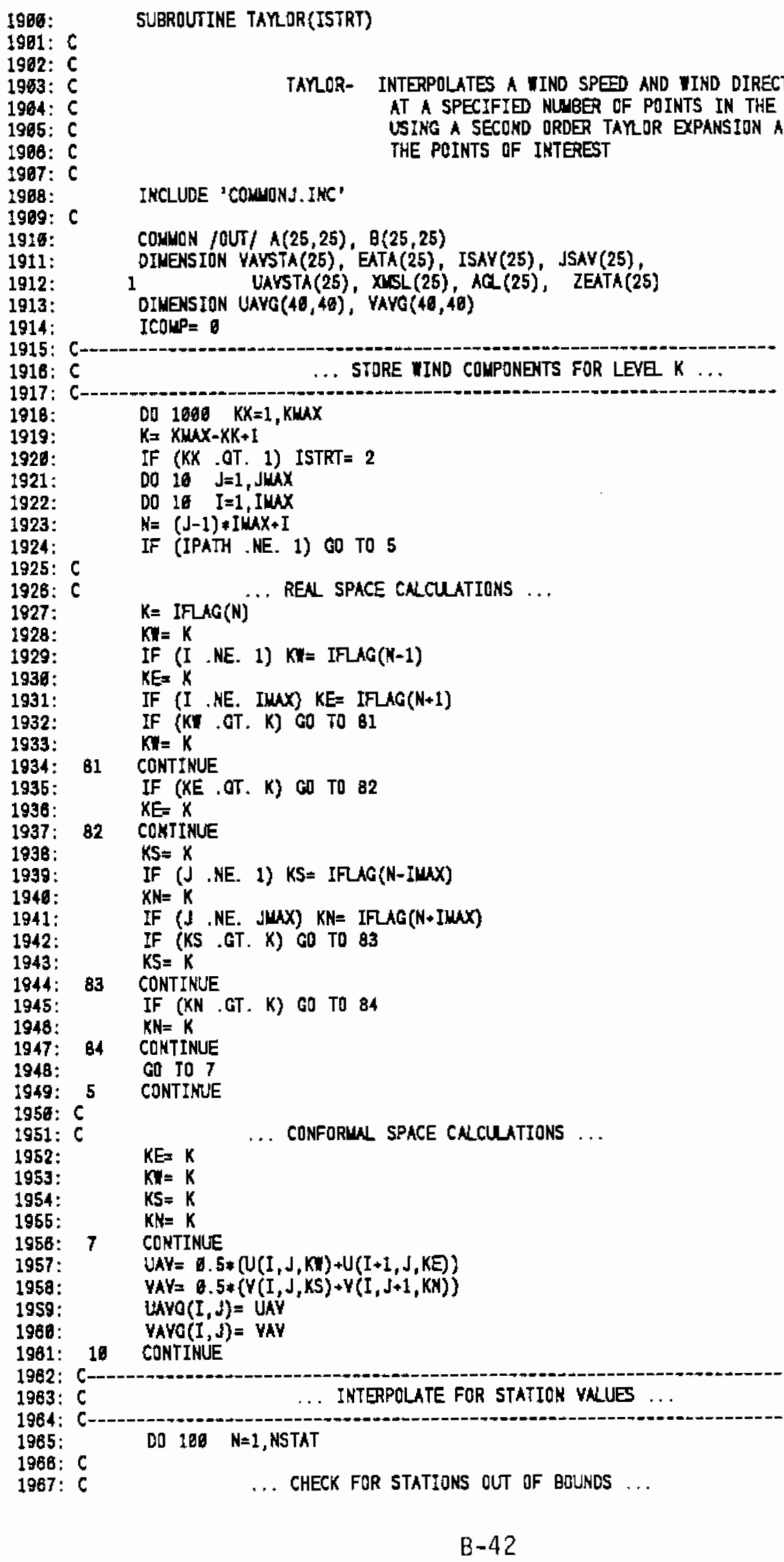




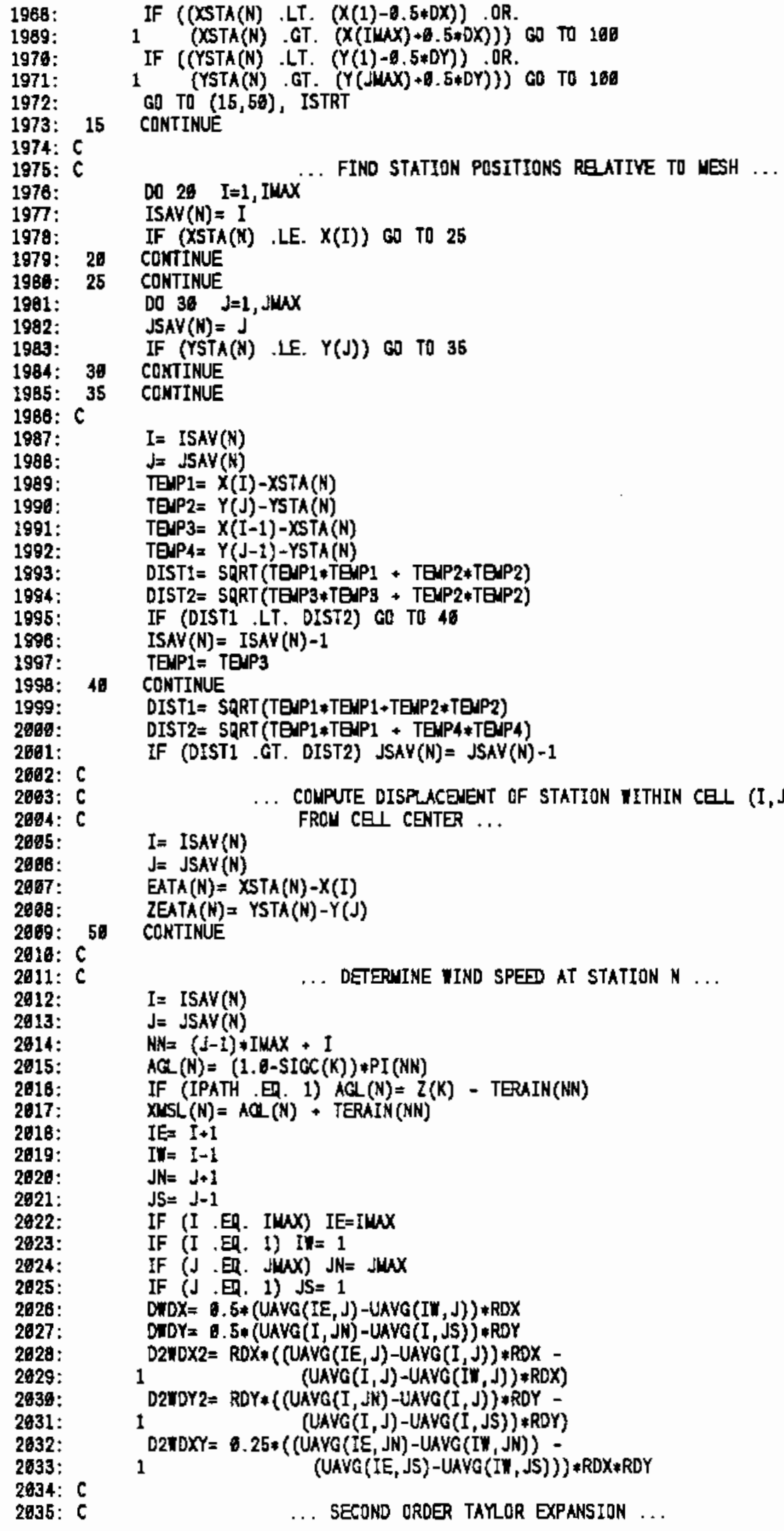




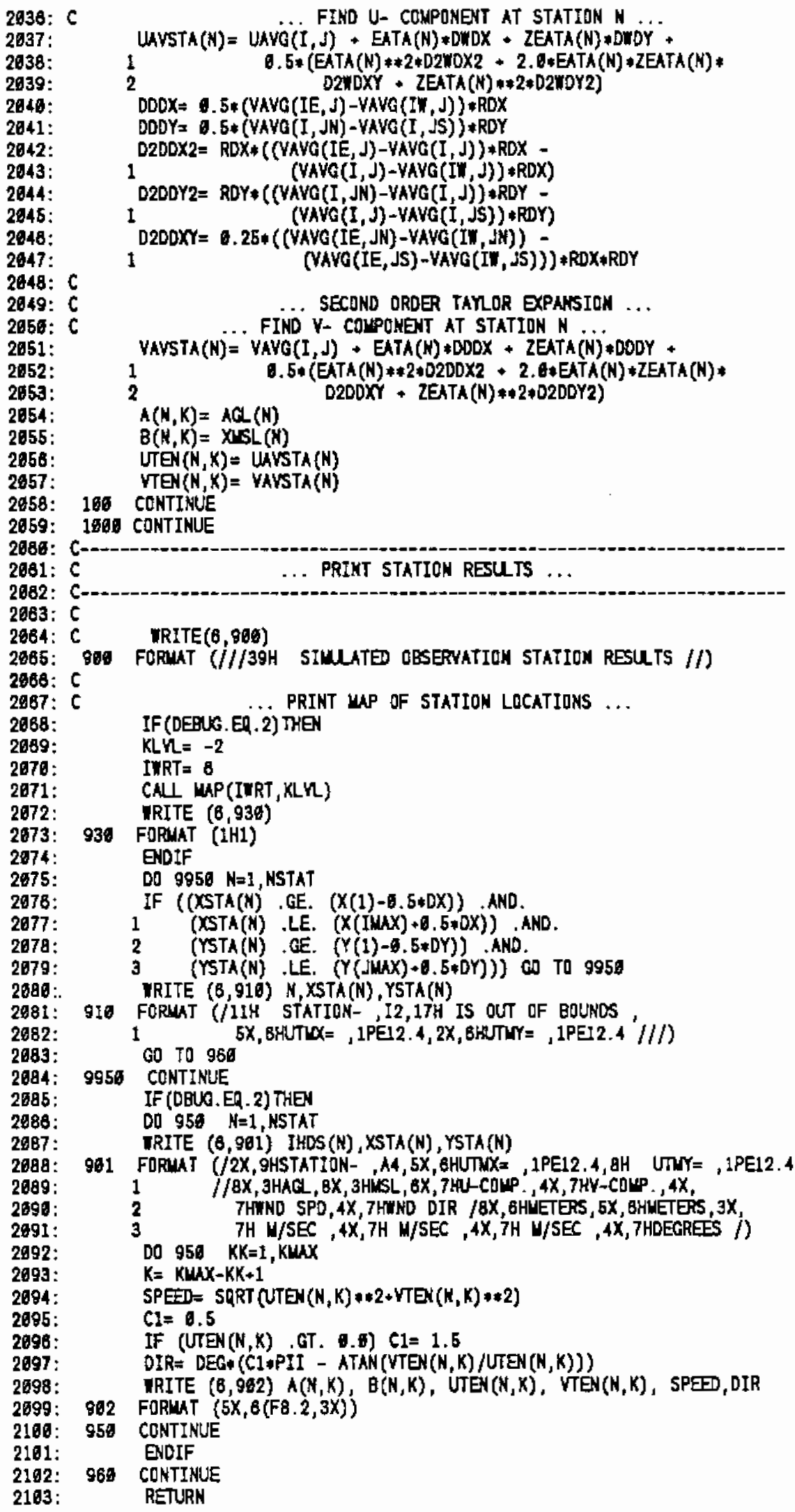




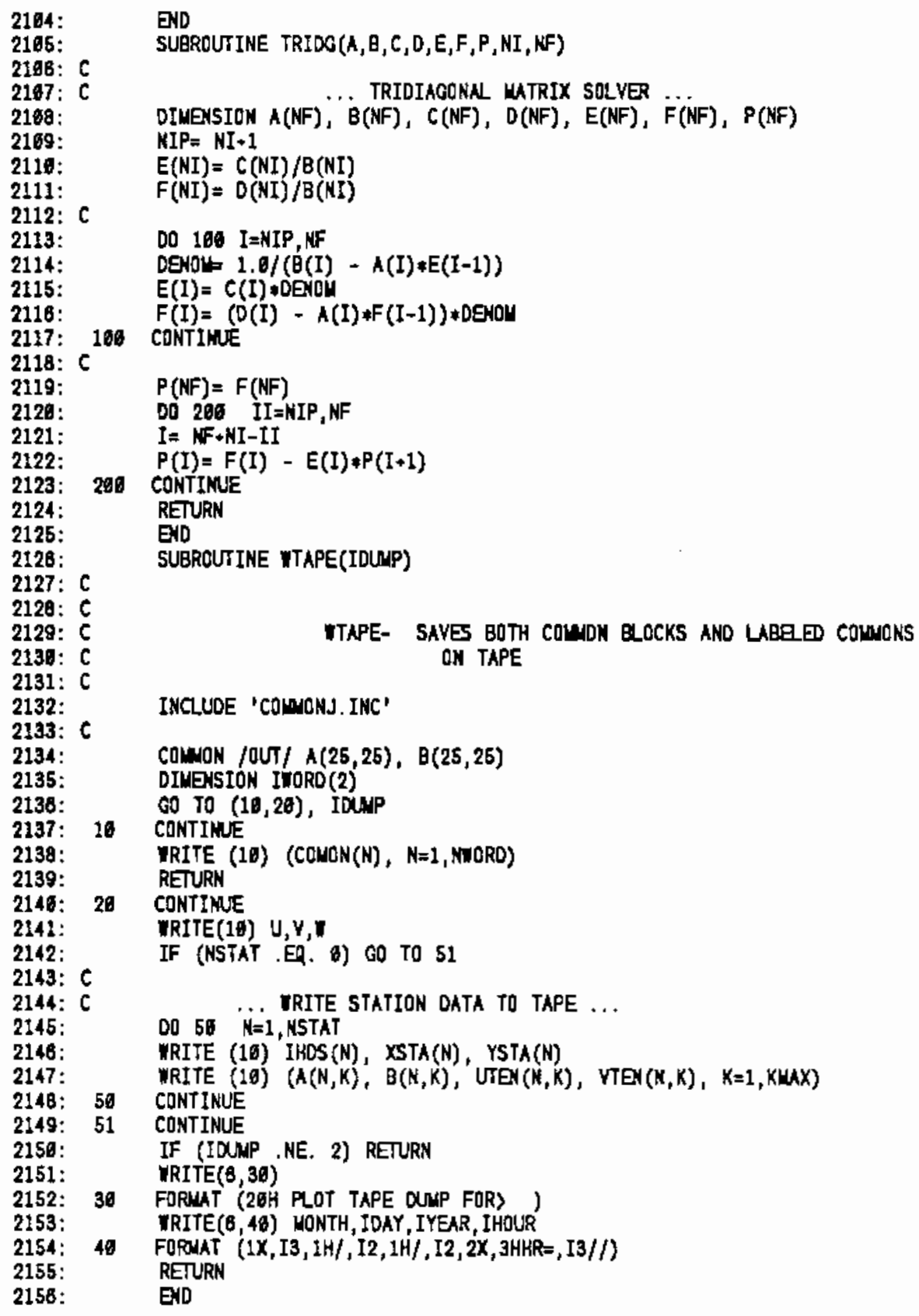




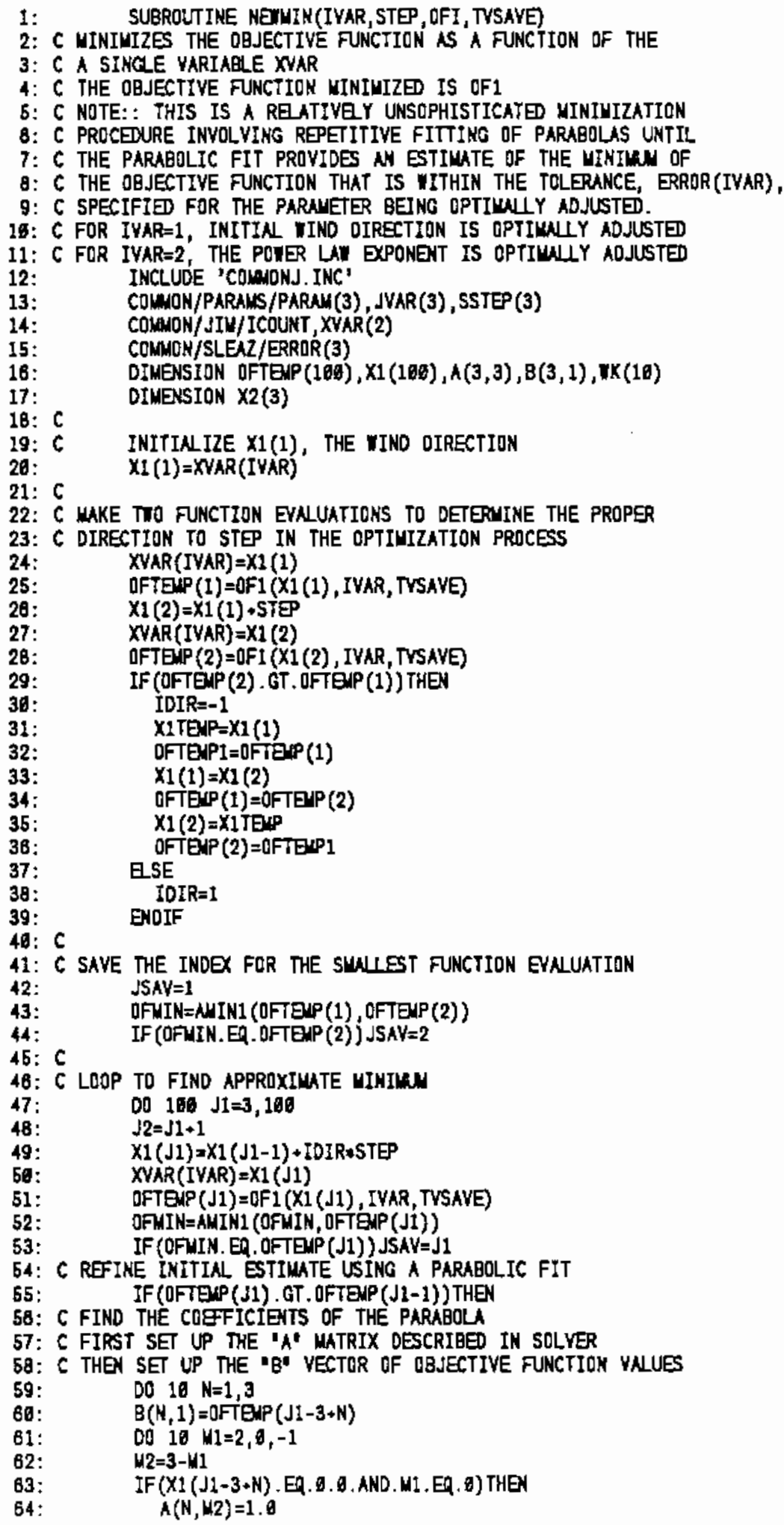




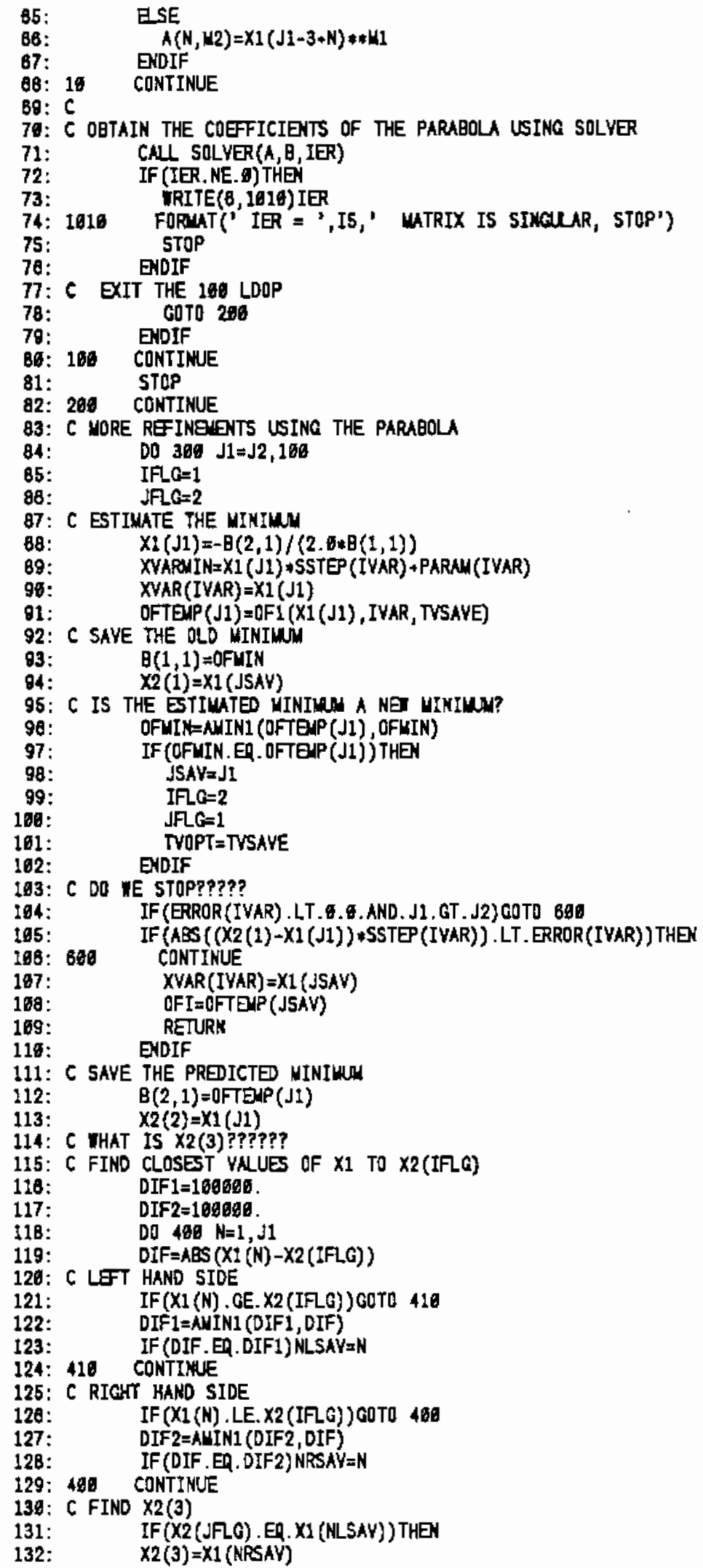




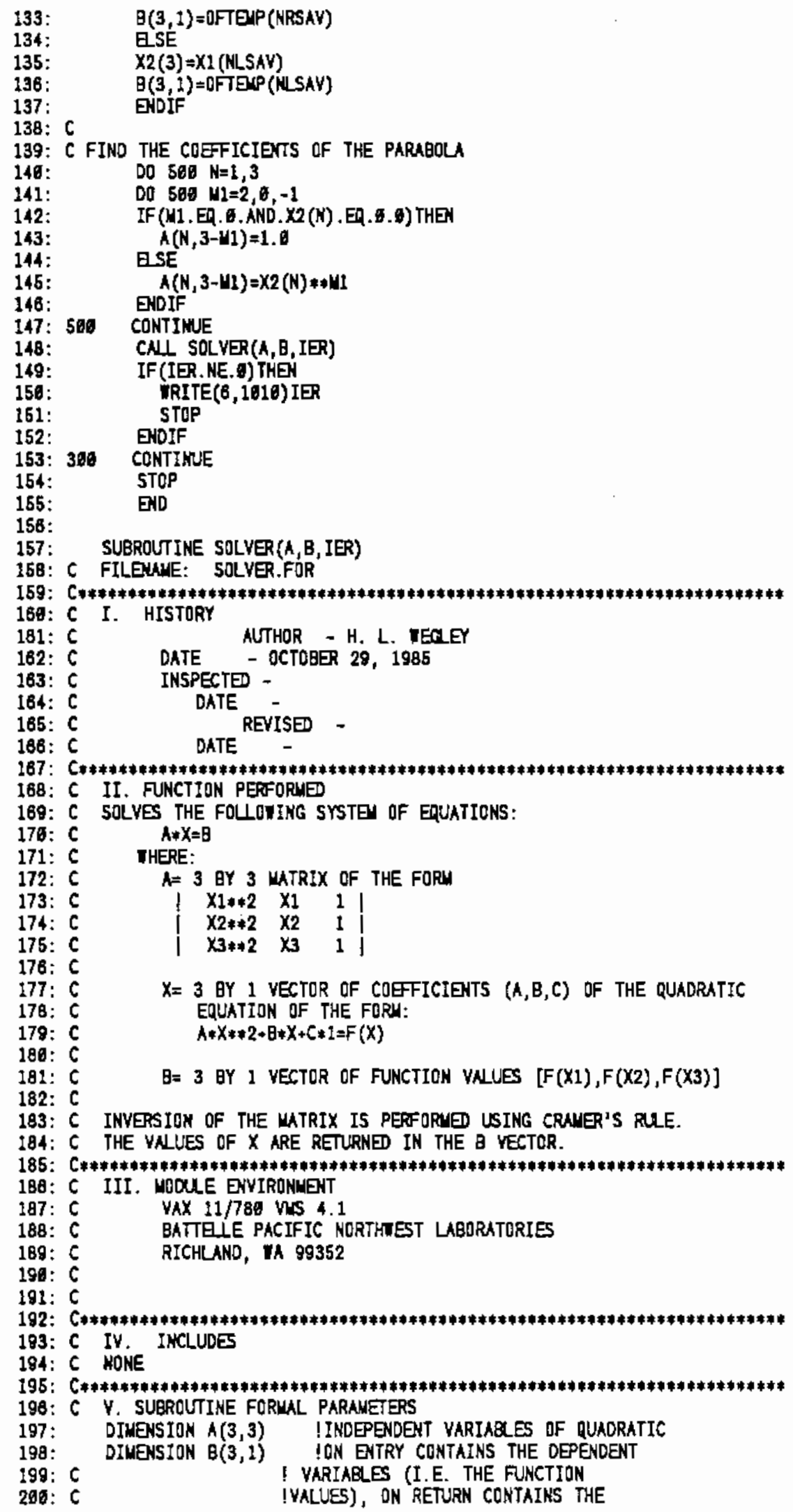




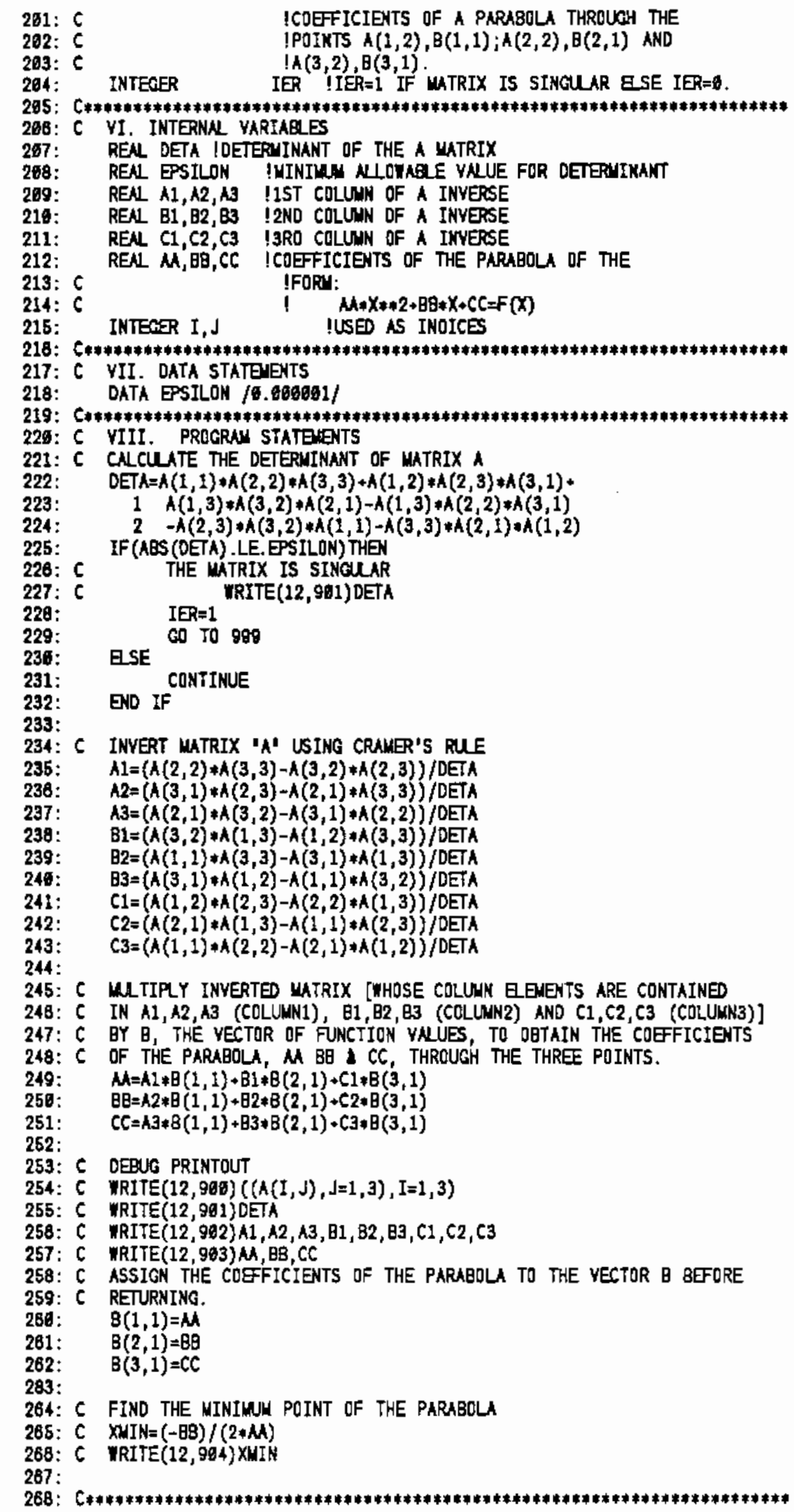


269: C IX. FORHAT STATENENTS

276: C906 FORMAT(1X, THE DRIGINAL A MATRIX IS: ', 3(/1X,3F10.4))

271: C901 FORMAT $(1 X, / /$ ' THE DETERUIHANT OF $A$ IS: ' $F 15.6 / /)$

272: C9ø2 FORMAT(1X, ${ }^{\prime}$ THE INVERTED A MATRIX IS: $\left.{ }^{2}, 3(/ 1 X, 3 F 15 . S) / /\right)$

273: C993 FORUAT(1X,' THE COGFICIENTS DF THE PARABOLA ARE:', ' $M=$ ',

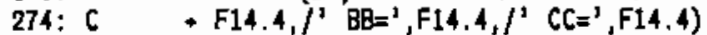

275: C964 FORMAT(1X, 'THE NIRTMU POINT OF THE PARABOLA = ',F14.4)

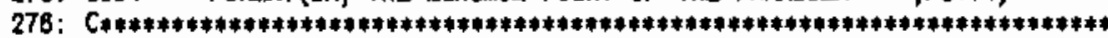

277: 999 RETURK

278:

END 
FILE: OF.FOR

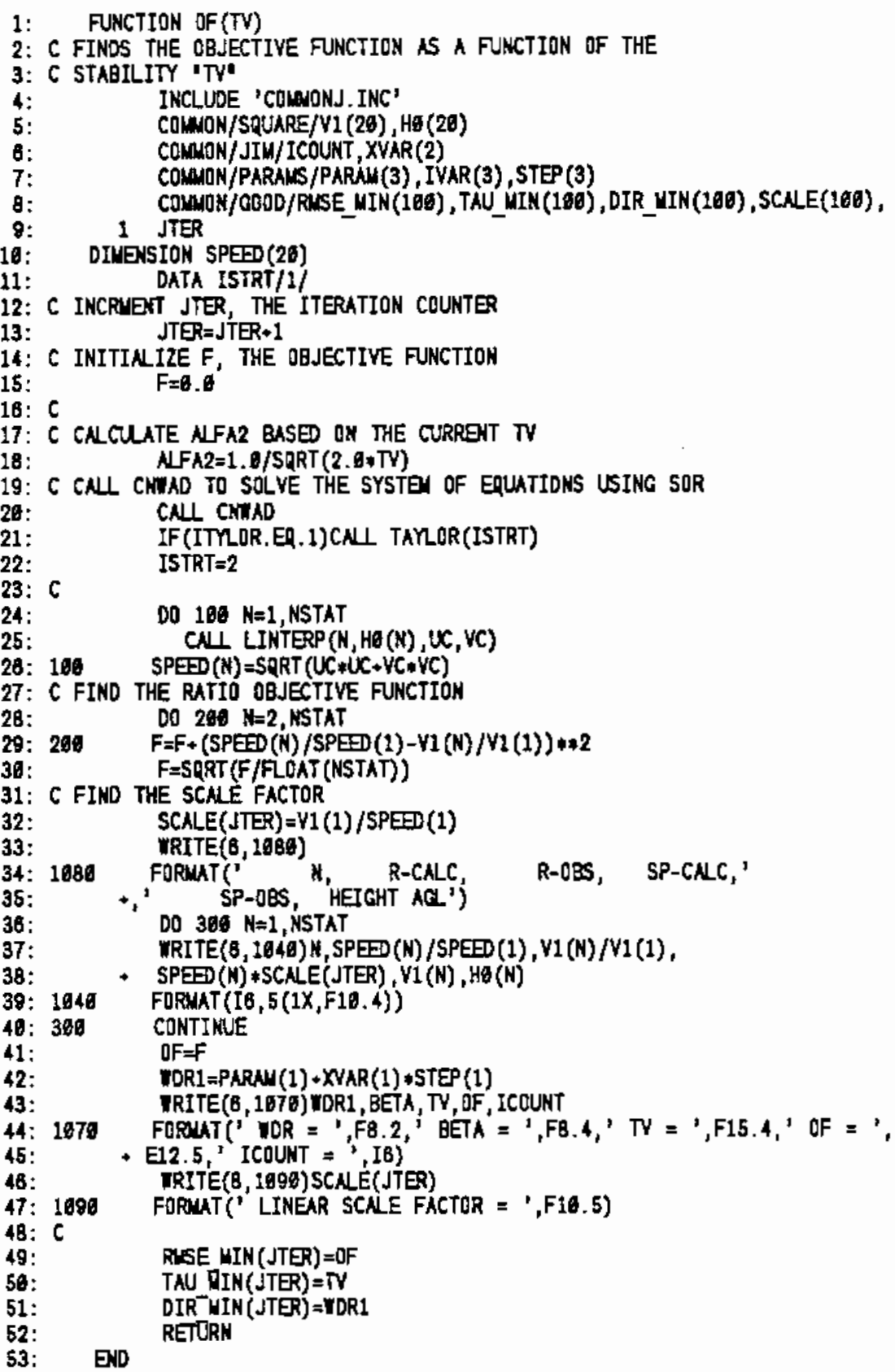




\section{FILE: OFI.FOR}

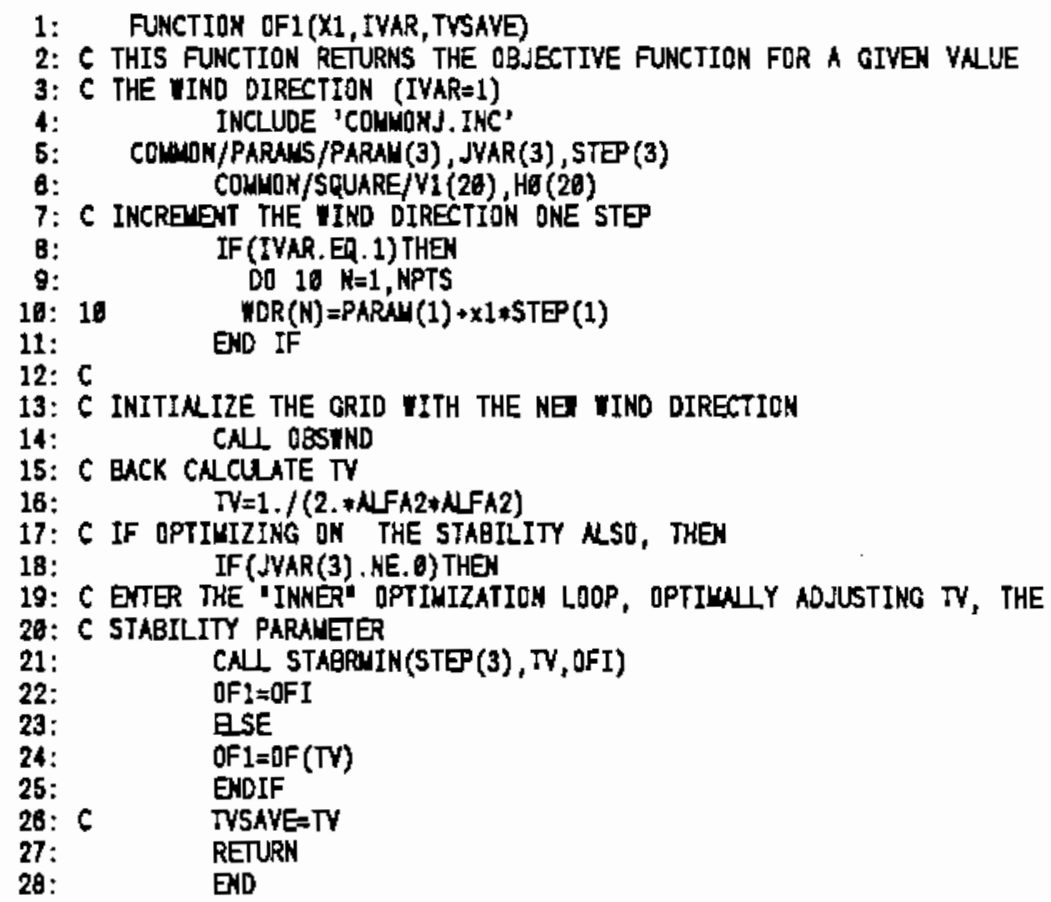


FILE： STABR.FOR

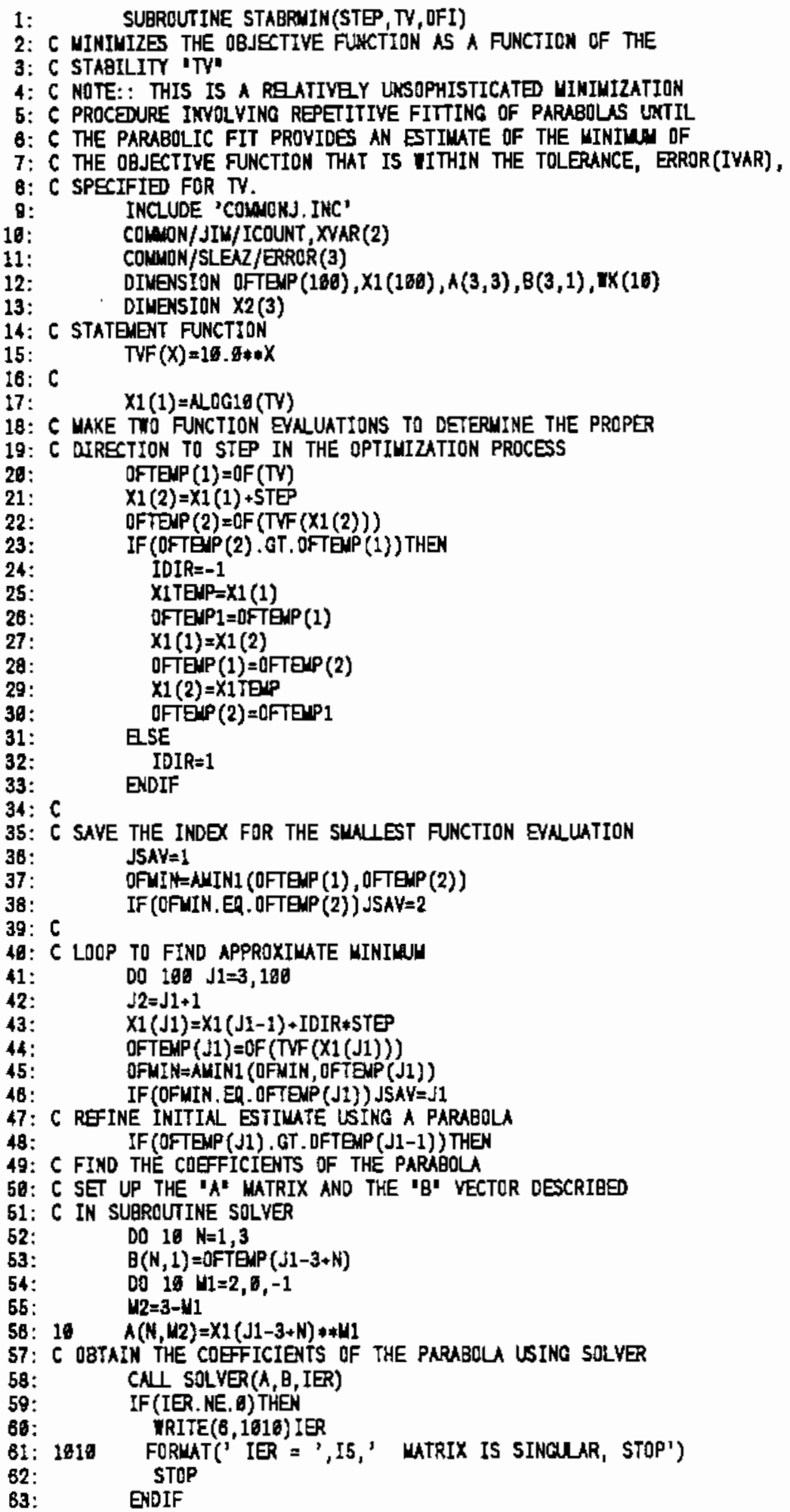




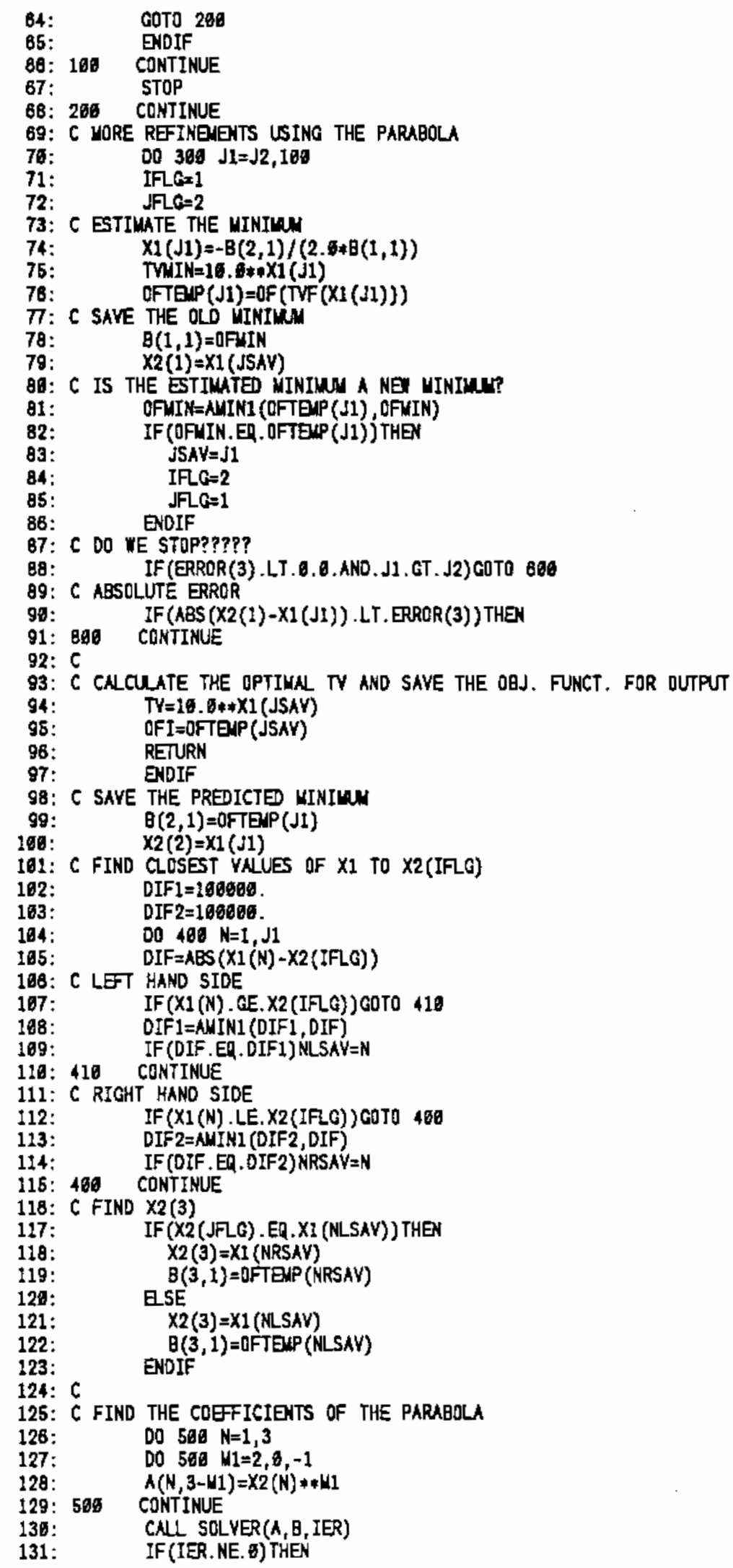




$\begin{array}{ll}\text { 132: } & \text { IRITE }(6,1918) \text { IER } \\ \text { 133: } & \text { STOP } \\ \text { 134: } & \text { ENOIF } \\ \text { 135: } 360 & \text { CONTINUE } \\ \text { 136: } & \text { STOP } \\ 137: & \text { ENO }\end{array}$




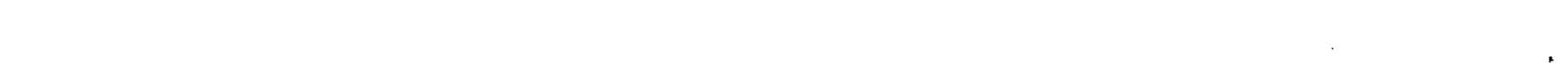




\section{APPENDIX C}

\section{TERRAIN DATA FOR MODEL TEST CASE}


APPENDIX C

\section{TERRAIN DATA FOR MODEL TEST CASE}

This appendix provides a listing of the terrain data used for the test case. These data are the heights above sea level (in meters) for each point of the 40 by 40 grid used for the test case. The first terrain elevation that is read by the code, in this case $181.30 \mathrm{~m}$, corresponds to the lower left-hand corner of the modeling grid. The terrain data is in 8F10.2 format.

Figure 3.1 is a contour plot of these data. 
.

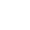




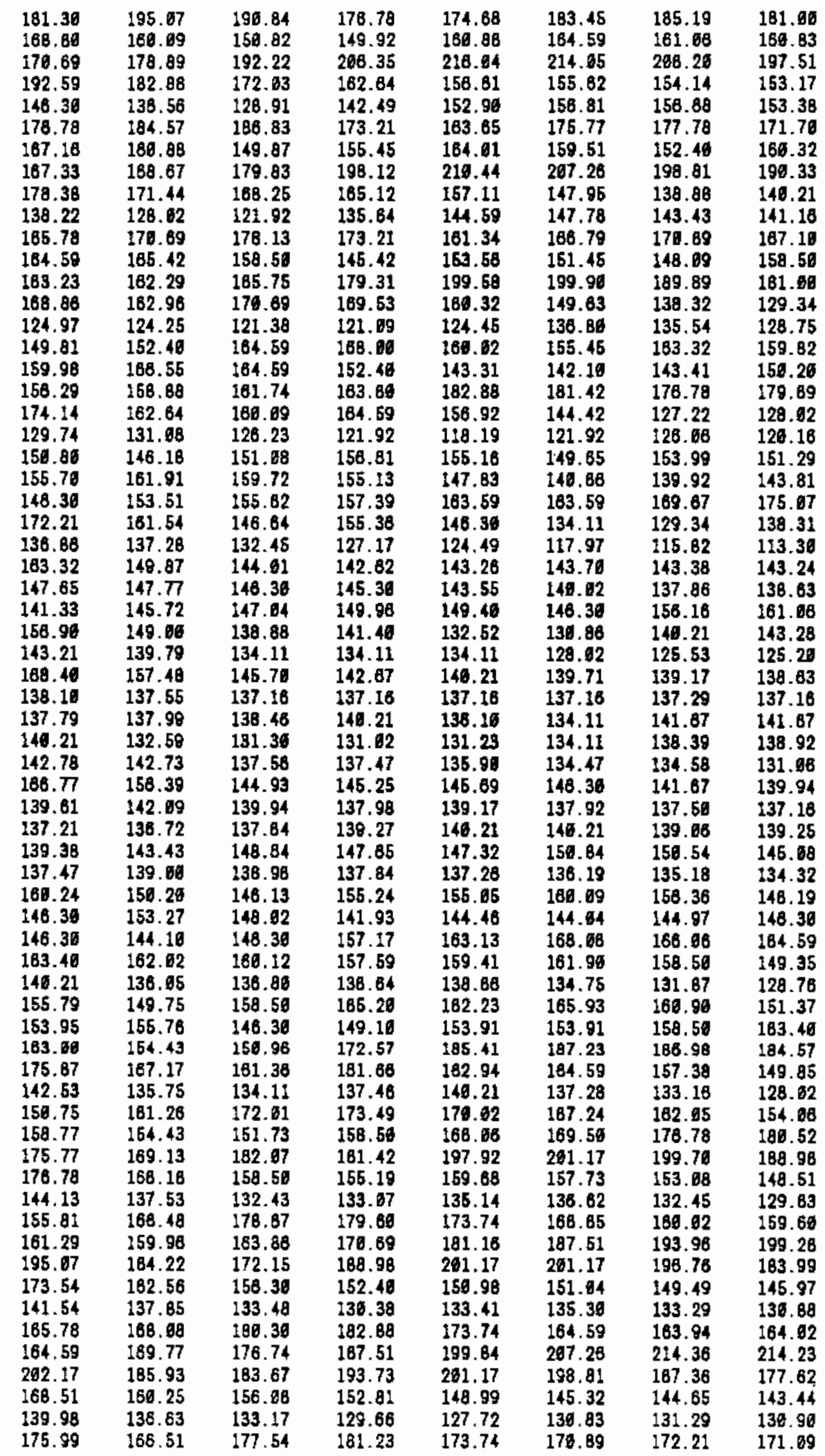




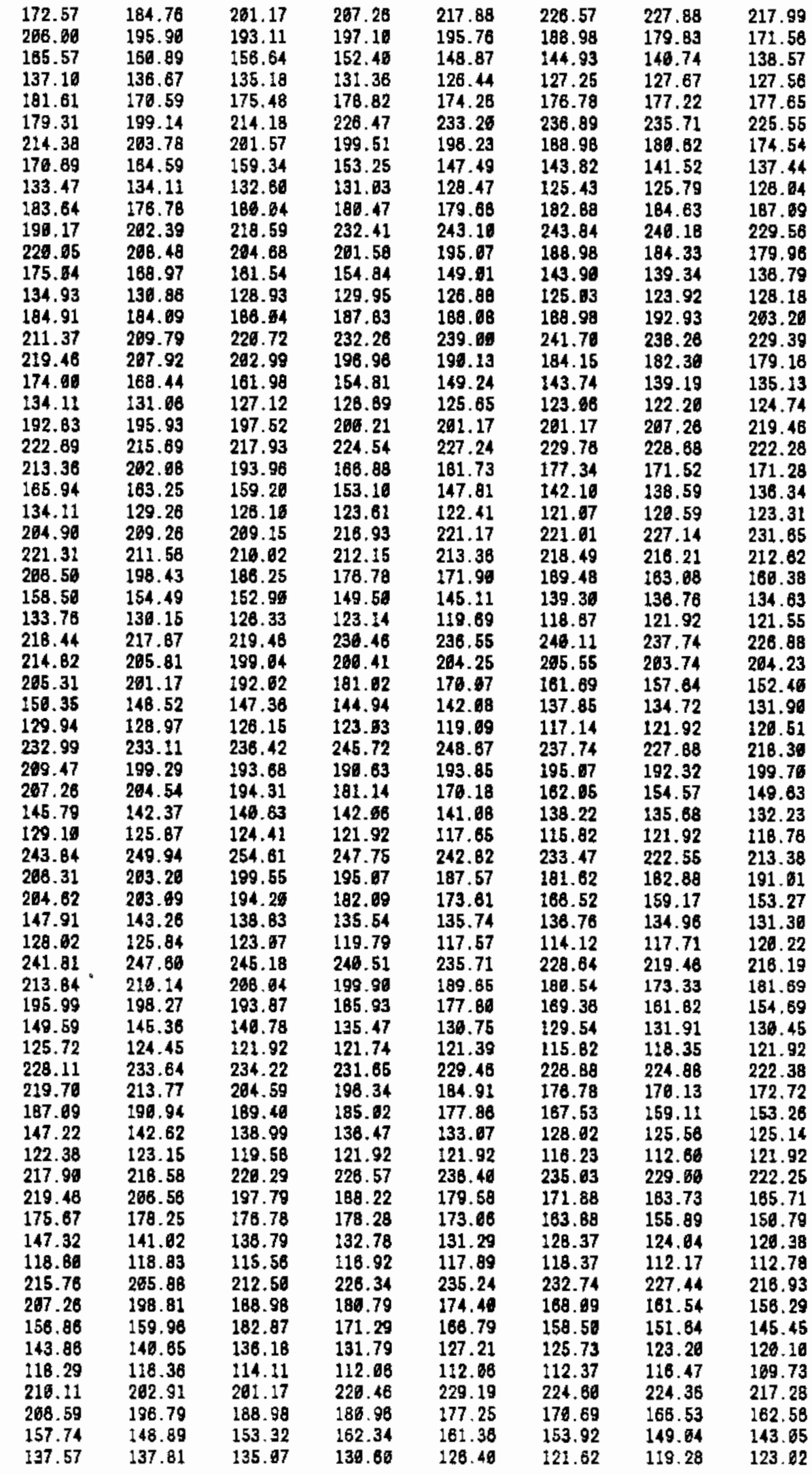




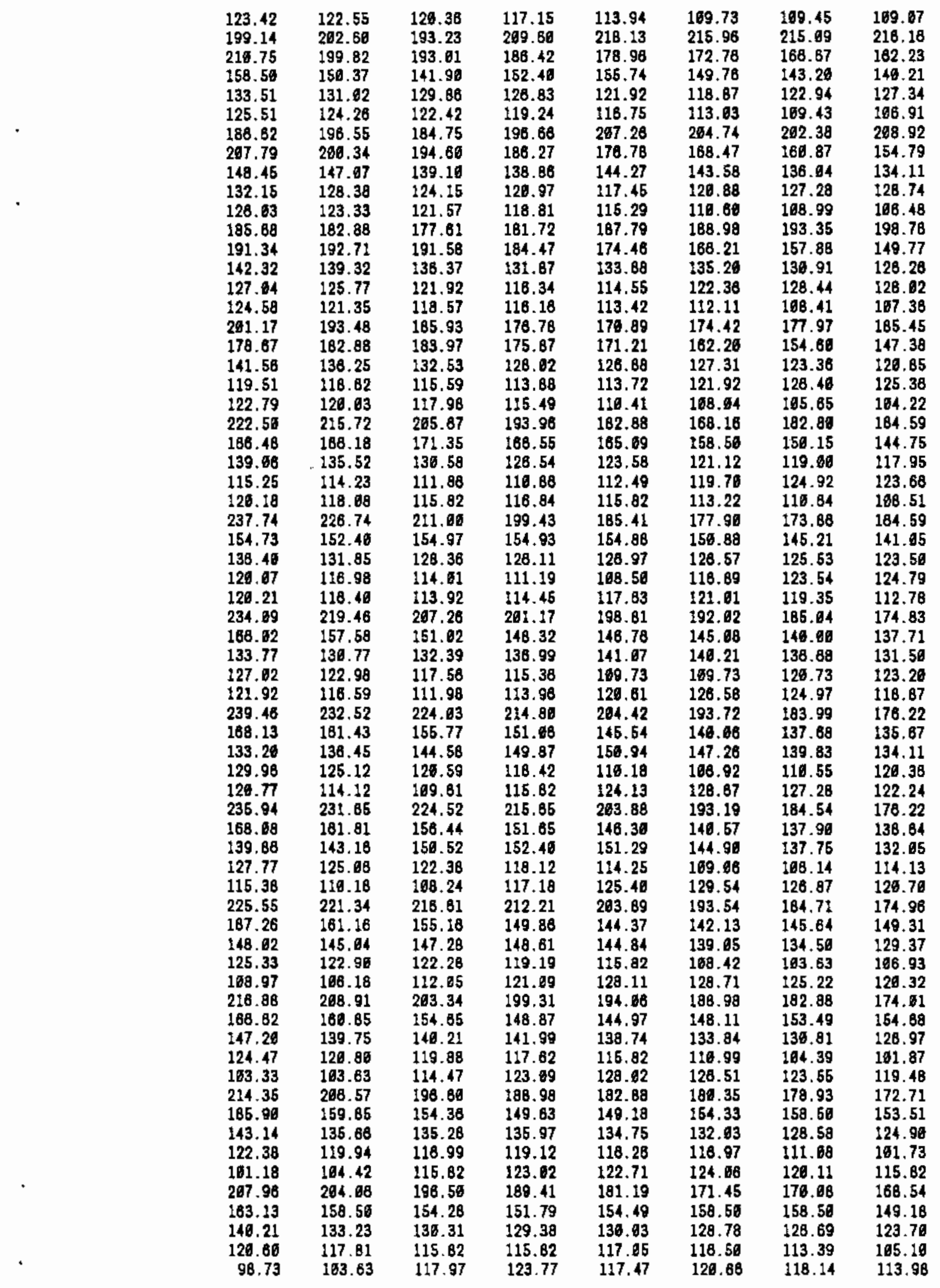


.

.

$+$ 
APPENDIX D

LISTING OF THE OBJECTIVE FUNCTION AS

A FUNCTION OF ITERATION NUMBER 


\section{APPENDIX D}

\section{LISTING OF THE OBJECTIVE FUNCTION AS}

A FUNCTION OF ITERATIONN NUMBER

When the switch on the last line of the input file is set equal to "1", the model is operated in a special mode whose purpose is to find how the objective function varies with iteration number in the subroutine CNWAD. This appendix contains a listing of the objective function and iteration number obtained using the input data of Figure 3.2 (with the appropriate switch set to 1 ). The first 50 values of the objective function are plotted in Figure 3.5 as the curve associated with $\operatorname{LOG}(T V)=0.0$. 


\begin{tabular}{|c|c|c|c|}
\hline $\begin{array}{c}\text { ITERATION } \\
1 \\
2 \\
3 \\
4 \\
5 \\
8 \\
7 \\
8 \\
9 \\
16 \\
11 \\
12 \\
13 \\
14 \\
25 \\
18 \\
17 \\
18 \\
18 \\
29 \\
21 \\
22 \\
23 \\
24 \\
25 \\
26 \\
27 \\
28 \\
28 \\
36 \\
31 \\
32 \\
33 \\
34 \\
35 \\
38 \\
37 \\
38 \\
39 \\
46 \\
41 \\
42 \\
43 \\
44 \\
45 \\
46 \\
47 \\
48 \\
49 \\
56 \\
51 \\
52 \\
53 \\
54 \\
55 \\
58 \\
57 \\
58 \\
59 \\
89 \\
81 \\
82 \\
63 \\
64 \\
85 \\
66\end{array}$ & 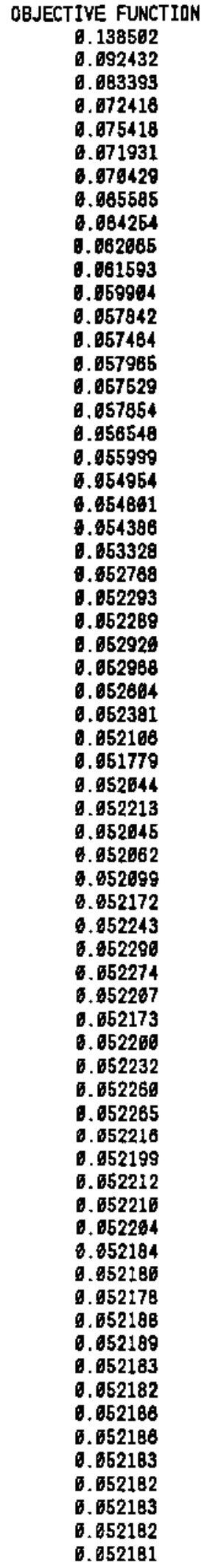 & 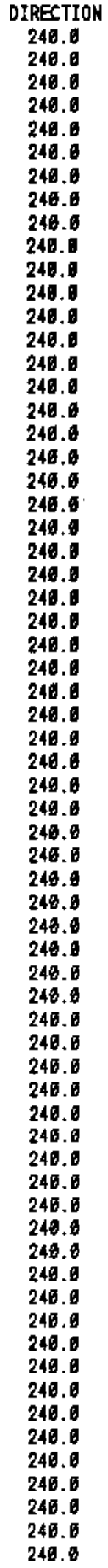 & 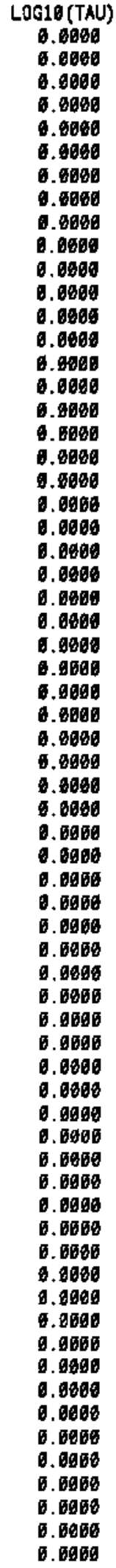 \\
\hline
\end{tabular}




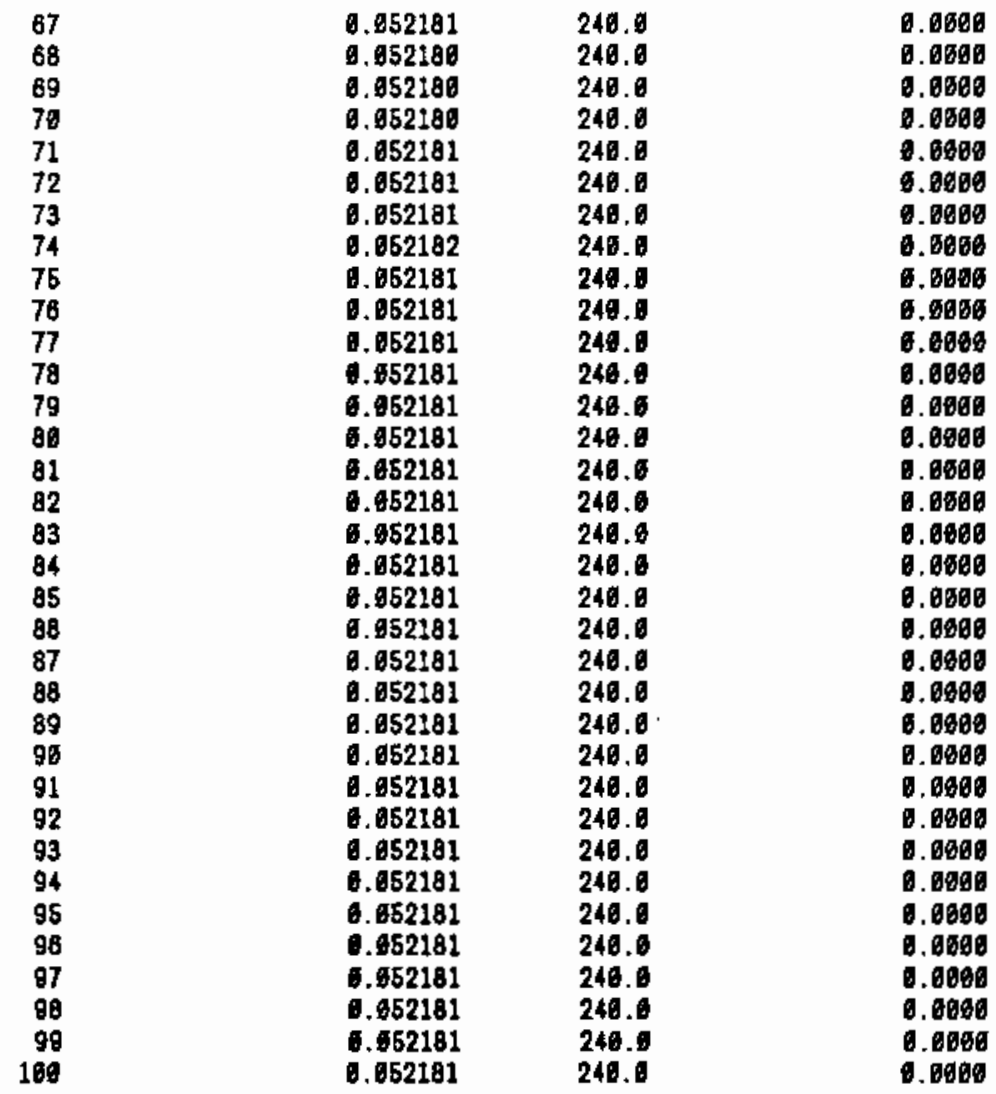


APPENDIX E

PRINTED OUTPUT FOR THE TEST CASE 


\section{APPENDIX E}

\section{PRINTED OUTPUT FOR THE TEST CASE}

This appendix provides the information written to logical unit 6 during a model run. The input data for the test case (Figure 3.2) was used to generate this output. The last lines of the output contain optimat values for TV and WDR and the minimum objective function. 
. 
TEST CASE DF NOABL WITH OPTIUIZATION ON 8 DATA LOCATIOHS

INPUT YNLES TO PROGRN ELNK COMOH

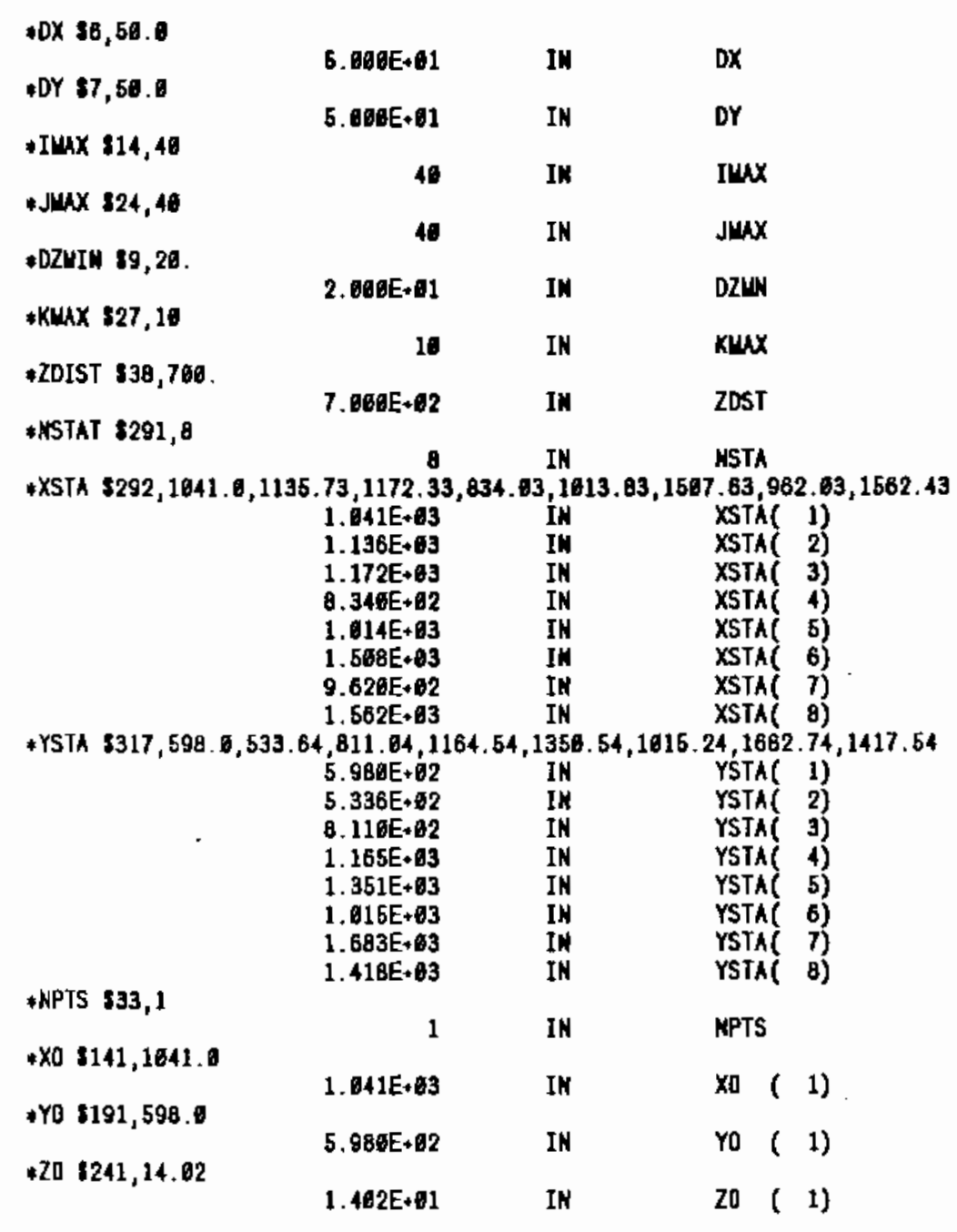




\begin{tabular}{|c|c|c|c|}
\hline •WSPD $\$ 91,18.3$ & 1. $839 E+01$ & IN & ISPD( 1) \\
\hline +IDR $\$ 41,240.6$ & $2.460 E \cdot 02$ & IN & YDR ( 1) \\
\hline *ITURX 848,25 & 25 & IN & $\operatorname{IT} x$ \\
\hline *ITERAN 819,1 & 1 & IN & ITRN \\
\hline *ITYOR 226,1 & 1 & IN & \\
\hline
\end{tabular}

* Blank field INdicates end af DATa INPUT * 
*** CAlCULATION TO BE PERFoRIED IN CONFDFula $(X, Y, S)$ SPACE ***

I N P U T DATA

CARD INPUT DATA

PROBLEY PARNETERS

\begin{tabular}{|c|c|c|c|c|c|c|c|c|c|}
\hline $\begin{array}{l}\text { NFA1 }= \\
\mathrm{OX}=\end{array}$ & $\begin{array}{r}0.7671 \\
50.0000\end{array}$ & $\begin{array}{l}\text { NFA2= } \\
\text { DY }=\end{array}$ & $\begin{array}{r}0.7071 \\
50.6000\end{array}$ & $\begin{array}{l}\text { 照T } A= \\
D Z=\end{array}$ & $\begin{array}{r}0.1429 \\
0.0808\end{array}$ & $\begin{array}{l}\text { CKVFSH= } \\
\text { DZUIN= }\end{array}$ & $\begin{array}{r}1.0000 \\
26.0000\end{array}$ & $\begin{array}{l}\text { DQUE= } \\
\text { EPSLN= }\end{array}$ & $0.1000 \mathrm{E}+60$ \\
\hline IDAY $=$ & 1 & IEDIT $=$ & 0 & IHOUR= & 1 & IMAX $=$ & 40 & $\mathrm{I} U \mathrm{HN}=$ & \\
\hline INXX = & 30 & IPATH= & 2 & ISIG & 3 & ITERAN $=$ & 1 & ITYOR= & \\
\hline ININD= & 1 & IYEAR= & 1 & $\mathrm{I} 2 \mathrm{D}=$ & 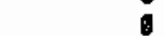 & $\operatorname{Ju} x=$ & 40 & $\mathrm{JMN}=$ & \\
\hline$J U X=$ & 36 & $\cos x=$ & 16 & $\mathrm{KUN}=$ & 1 & $X M X=$ & 16 & MONTH= & \\
\hline UPS $=$ & 1 & NDAYS= & 1 & NPTS= & 1 & OLEG & 1.8544 & GRIGKX = & \\
\hline ORIGNY= & - & QRIGHZ= & - $9006 \mathrm{E}+8 \theta$ & ZOIST= & $0.7608 \mathrm{E}+63$ & $D M P=$ & 0.0080 & QTOP= & \\
\hline ATOP= & 0.0800 & $\mathrm{ZBL}=$ & 200.0900 & NUA $=$ & 0 & IT $u x=$ & 25 & & \\
\hline
\end{tabular}

SUPFACE OBSERVATION DATA

\begin{tabular}{|c|c|c|c|c|}
\hline $\begin{array}{l}\text { WS } \\
\text { y/SEC }\end{array}$ & $\begin{array}{c}\text { WD } \\
\text { DECREE }\end{array}$ & $\begin{array}{c}\text { XO } \\
\text { MEJERS }\end{array}$ & $\begin{array}{c}\text { Y0 } \\
\text { METERS }\end{array}$ & $\begin{array}{c}20 \\
\text { WETERS }\end{array}$ \\
\hline
\end{tabular}

SIMUATED DUTPUT STATION LOCATIONS

\begin{tabular}{|c|c|c|c|c|c|c|c|c|c|c|c|}
\hline STATION & $\begin{array}{c}\text { UTUX } \\
\text { UETERS }\end{array}$ & $\begin{array}{c}\text { UTUY } \\
\text { WETERS }\end{array}$ & STATION & $\begin{array}{c}\text { UTWX } \\
\text { UETERS }\end{array}$ & $\begin{array}{c}\text { UTUY } \\
\text { MEIERS }\end{array}$ & STATION & $\begin{array}{c}\text { UTWX } \\
\text { UETERS }\end{array}$ & $\begin{array}{c}\text { UTrY } \\
\text { HETERS }\end{array}$ & STAIION & $\begin{array}{c}\text { UTWX } \\
\text { UETERS }\end{array}$ & $\begin{array}{c}\text { UTHY } \\
\text { METERS }\end{array}$ \\
\hline $\begin{array}{l}1 \\
5\end{array}$ & $\begin{array}{l}1.8410 E+83 \\
1.0138 E+83\end{array}$ & $\begin{array}{l}\text { 5. } 9866 \mathrm{E}+62 \\
1.3565 \mathrm{E}+83\end{array}$ & 2 & $\begin{array}{l}1.1357 \mathrm{E}+63 \\
1.5876 \mathrm{E}+83\end{array}$ & $\begin{array}{l}5.3364 \mathrm{E}+\theta 2 \\
1.6152 \mathrm{E}+83\end{array}$ & $\begin{array}{l}3 \\
7\end{array}$ & $\begin{array}{l}1.1723 \mathrm{E}+63 \\
9.6293 \mathrm{E}+82\end{array}$ & $\begin{array}{l}8.1164 \mathrm{E}+62 \\
1.6827 \mathrm{E}+63\end{array}$ & 8 & $\begin{array}{l}0.3463 \mathrm{E}+62 \\
1.5824 \mathrm{E}+63\end{array}$ & $\begin{array}{l}1.1645 E+63 \\
1.4175 E+83\end{array}$ \\
\hline
\end{tabular}




\begin{tabular}{|c|c|c|c|c|c|c|c|c|c|c|c|c|c|c|c|}
\hline \multirow{2}{*}{\multicolumn{3}{|c|}{ TERRAIN DATA (MEIERS) }} & \multirow[b]{2}{*}{ HEICHT } & \multirow[b]{2}{*}{1} & \multirow[b]{2}{*}{ HEIGHT } & \multirow[b]{2}{*}{ I } & \multirow[b]{2}{*}{ HEICHT } & \multirow[b]{2}{*}{ I } & \multirow[b]{2}{*}{ HEIGHT } & & \multirow[b]{2}{*}{ HEIGHT } & \multirow[b]{2}{*}{ I J } & \multirow[b]{2}{*}{ HEIGHT } & \multirow[b]{2}{*}{ I J } & \multirow[b]{2}{*}{ HEIGHT } \\
\hline & & & & & & & & & & & & & & & \\
\hline $\begin{array}{rr}1 & 40 \\
9 & 40 \\
17 & 40 \\
25 & 40 \\
33 & 40\end{array}$ & $\begin{array}{r}268.6 \\
163.1 \\
149.2 \\
120.6 \\
98.7\end{array}$ & $\begin{array}{r}240 \\
1040 \\
1840 \\
2840 \\
3440\end{array}$ & $\begin{array}{l}264.1 \\
158.5 \\
133.2 \\
117.8 \\
103.6\end{array}$ & $\begin{array}{rl}3 & 40 \\
11 & 40 \\
19 & 49 \\
27 & 46 \\
35 & 40\end{array}$ & $\begin{array}{l}198.5 \\
154.9 \\
130.3 \\
115.8 \\
118.8\end{array}$ & $\begin{array}{rr}4 & 40 \\
12 & 40 \\
20 & 40 \\
28 & 40 \\
38 & 40\end{array}$ & $\begin{array}{l}189.4 \\
151.8 \\
129.4 \\
115.8 \\
123.8\end{array}$ & $\begin{array}{rl}5 & 4 \\
13 & 4 \\
21 & 4 \\
29 & 4 \\
37 & 4\end{array}$ & $\begin{array}{l}181.2 \\
154.5 \\
136.0 \\
117.1 \\
117.5\end{array}$ & $\begin{array}{rr}8 & 4 \\
14 & 4 \\
22 & 4 \\
30 & 48 \\
38 & 48\end{array}$ & $\begin{array}{l}171.4 \\
158.5 \\
120.8 \\
118.5 \\
120.7\end{array}$ & $\begin{array}{rr}7 & 48 \\
15 & 48 \\
23 & 48 \\
31 & 48 \\
39 & 48\end{array}$ & $\begin{array}{l}176.1 \\
158.5 \\
126.7 \\
113.4 \\
118.1\end{array}$ & $\begin{array}{rr}840 \\
164 \\
2440 \\
3240 \\
4040\end{array}$ & $\begin{array}{l}168.5 \\
149.2 \\
123.7 \\
165.1 \\
114.8\end{array}$ \\
\hline 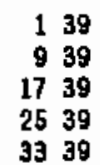 & $\begin{array}{l}214.4 \\
185.9 \\
143.1 \\
122.4 \\
161.2\end{array}$ & $\begin{array}{rr}2 & 39 \\
18 & 39 \\
18 & 39 \\
28 & 39 \\
34 & 39\end{array}$ & $\begin{array}{l}208.8 \\
159.8 \\
135.9 \\
119.9 \\
164.4\end{array}$ & $\begin{array}{rr}3 & 39 \\
11 & 39 \\
19 & 39 \\
27 & 39 \\
35 & 39\end{array}$ & $\begin{array}{l}196.8 \\
154.4 \\
135.3 \\
117.8 \\
115.8\end{array}$ & $\begin{array}{rr}4 & 99 \\
12 & 39 \\
28 & 39 \\
28 & 39 \\
36 & 39\end{array}$ & $\begin{array}{l}189.6 \\
149.6 \\
136.0 \\
119.1 \\
123.0\end{array}$ & $\begin{array}{rr}6 & 3 \\
13 & 3 \\
21 & 3 \\
29 & 35 \\
37 & 3\end{array}$ & $\begin{array}{l}182.9 \\
149.2 \\
134.0 \\
118.3 \\
122.7\end{array}$ & $\begin{array}{rr}6 & 39 \\
14 & 38 \\
22 & 38 \\
30 & 38 \\
38 & 39\end{array}$ & $\begin{array}{l}180.4 \\
154.3 \\
132.0 \\
117.0 \\
124.1\end{array}$ & $\begin{array}{rr}7 & 39 \\
15 & 39 \\
23 & 39 \\
31 & 39 \\
39 & 39\end{array}$ & $\begin{array}{l}170.8 \\
150.5 \\
120.8 \\
111.1 \\
120.1\end{array}$ & $\begin{array}{rr}6 & 39 \\
16 & 39 \\
24 & 39 \\
32 & 39 \\
49 & 39\end{array}$ & $\begin{array}{l}172.7 \\
153.6 \\
124.8 \\
101.7 \\
115.8\end{array}$ \\
\hline
\end{tabular}

THE STATION IIND SPEEDS ARE ;

$\begin{array}{ccccc}18.3060 & 17.4008 & 13.4600 & 13.4600 & 11.6000\end{array}$

$11.860012 .5090 \quad 12.1068$

THE HEICHTS AC (NETERS) FOR EACH STATION ARE:

$14.0214 .02 \quad 14.0214 .0214 .02 \quad 14.0214 .62 \quad 14.02$

THE INITINL PARAMETERS FOR DIRECTION AND TV = 0.2400E+63 0.1608E+01

IVAR (OIRECIION AND TV) $=11 \quad 1$
THE SIEP SIZES FOR DIRECTIOH AND LOG(TV) $=0.5000 E+01.2000 E+00$

ABSOLUTE ERRORS FOR DIRECTIOH AND LOG(TV $=0.5000 \mathrm{E}+000.5000 \mathrm{E}-01$

MXIUW HEIGHT OF TERRAIN (UETERS) $=254.810$

$\begin{array}{rr}\text { HINIMU HEIGHT OF TERRIN (UETERS) }= & 98.730\end{array}$ 
MESH PARANETERS

LOCATION OF ORIGIN (METERS)

$\begin{array}{ccc}\text { DRIGNX } & \text { ORIGNY } & \text { DRIGNZ } \\ 0.0006 \mathrm{E}+00 & 8.0000 \mathrm{E}+68 & 9.8736 \mathrm{E}+81\end{array}$

WESH SPACING (HETERS)

$\begin{array}{ccc}\text { DX } & \text { DY } & \text { DZHIN } \\ 66.00 & 50.00 & 26.00\end{array}$

EXPANSION FACTOR (QNMA), FOR GEAMETRIC PROGRESSION= $\quad 1.28631709$

\begin{tabular}{|c|c|c|c|c|c|c|c|}
\hline \multicolumn{8}{|c|}{ X-ARRAY (LETERS) } \\
\hline$n_{1}$ & $25968 E+01$ & 2 & $7.5969 E+81$ & 3 & $1.2560 E+82$ & 4 & $1.750 B E+62$ \\
\hline 5 & 2.250BE+02 & 6 & $2.7600 \mathrm{E}+82$ & 7 & $3.2500 E+02$ & 8 & $3.7500 \mathrm{E}+02$ \\
\hline$g$ & $4.2500 E+02$ & 10 & $4.7500 \mathrm{E}+82$ & 11 & B. $25900+02$ & 12 & $6.7580 E+\theta 2$ \\
\hline 13 & 6. $2606 E+02$ & 14 & $6.75998 E+62$ & 15 & $7.2566 \mathrm{E}+62$ & 18 & $7.7506 E+62$ \\
\hline 17 & $0.2500 \mathrm{E}+62$ & 18 & B. $750 \theta E+02$ & 19 & $9.2560 E+82$ & 26 & $9.7504 \mathrm{E}+62$ \\
\hline 21 & $1.0259 \mathrm{E}+63$ & 22 & $1.0750 E+63$ & 23 & $1.1250 E+63$ & 24 & $1.1750 E+63$ \\
\hline 25 & $1.2250 E+03$ & 26 & $1.2756 E+63$ & 27 & $1.3250 E+193$ & 28 & $1.3760 E+63$ \\
\hline 29 & $1.4250 E+63$ & 30 & $1.4750 \mathrm{E}+83$ & 31 & $1.5250 \mathrm{E}+83$ & 32 & $1.5750 \mathrm{E}+03$ \\
\hline 33 & $18258 E+03$ & 34 & $1.6759 \mathrm{~g} \cdot 03$ & 35 & $17250 \mathrm{E}+63$ & 38 & $1.7758 \mathrm{E}+63$ \\
\hline 37 & $1.825 \theta E+83$ & 38 & $1.876 \theta E+93$ & 39 & $1.9250 E+03$ & 40 & $1.9759 \mathrm{E}+63$ \\
\hline$Y-A R R$ & (METERS) & & & & & & \\
\hline 1 & $2.5000 \mathrm{E}+61$ & 2 & $7.5000 \mathrm{E}+61$ & 3 & $1.2560 E+62$ & 4 & $1.7500 E+02$ \\
\hline 5 & $2.2560 E+92$ & 6 & $2.7500 \mathrm{E}+02$ & 7 & $3.2560 \mathrm{E}+62$ & 8 & $3.7500 \mathrm{E}+202$ \\
\hline 9 & $4.2560 \mathrm{E}+62$ & 16 & $4.7500 E+02$ & 11 & $5.2500 E+62$ & 12 & $5.7568 E+82$ \\
\hline 13 & $6.2500 E+62$ & 14 & $8.7608 E+62$ & 16 & $7.2500 \mathrm{E}+82$ & 16 & $7.7500 \mathrm{E}+92$ \\
\hline 17 & $8.2506 E+62$ & 18 & $8.7500 \mathrm{E}+62$ & 19 & $8.2500 E+02$ & 20 & $9.7500 \mathrm{E}+02$ \\
\hline 21 & $1.8250 E+63$ & 22 & $1.6750 E+03$ & 23 & $1.1256 \mathrm{E}+63$ & 24 & $1.1756 \mathrm{E}+63$ \\
\hline 25 & $1.2250 E+03$ & 26 & $1.2750 \mathrm{E}+03$ & 27 & $1.3250 E+03$ & 28 & $1.3758 E+83$ \\
\hline 29 & $1.4250 E+83$ & 39 & $1.4750 \mathrm{E}+03$ & 31 & 1. $5250 E+63$ & 32 & 1. $575 \theta E+03$ \\
\hline 33 & $1.6250 E+03$ & 34 & $1.8769 E+63$ & 35 & $1.7250 \mathrm{E}+03$ & 36 & $1.7750 \mathrm{E}+63$ \\
\hline 37 & $1.6258 \mathrm{E}+63$ & 38 & $1.8750 \mathrm{E}+03$ & 39 & $1.925 B E+03$ & 40 & $1.9750 \mathrm{E}+03$ \\
\hline 5 IOMA & ARRAY & & & & & & \\
\hline 1 & $0.0006 \mathrm{E}+60$ & 2 & 2.2922E- -01 & 3 & 4.1169E-61 & 4 & $5.5546 \mathrm{E}-61$ \\
\hline 5 & 6.8996E-81 & 8 & $7.8076 \mathrm{E}-81$ & 7 & $8.3284 \mathrm{E}-01$ & 8 & $8.9684 \mathrm{E}-61$ \\
\hline 9 & 8. 3542E-61 & 10 & $9.7143 \mathrm{E}-91$ & 11 & $1.0600 \mathrm{E}+00$ & & \\
\hline DSIG' & ARRAY & & & & & & \\
\hline 1 & 2. $2922 \mathrm{E}-01$ & 2 & 1.8187E-61 & 3 & $1.4431 E-61$ & 4 & $1.1456 \mathrm{E}-61$ \\
\hline 5 & $9.0851 \mathrm{E}-02$ & 8 & $7.2086 \mathrm{E}-62$ & 7 & $6.7197 \mathrm{E}-62$ & 8 & 4.5383E-62 \\
\hline 9 & $3.6869 \mathrm{E}-62$ & 10 & $2.8571 \mathrm{E}-02$ & 11 & $2.8671 \mathrm{E}-62$ & & \\
\hline
\end{tabular}


SICUA ARRAY

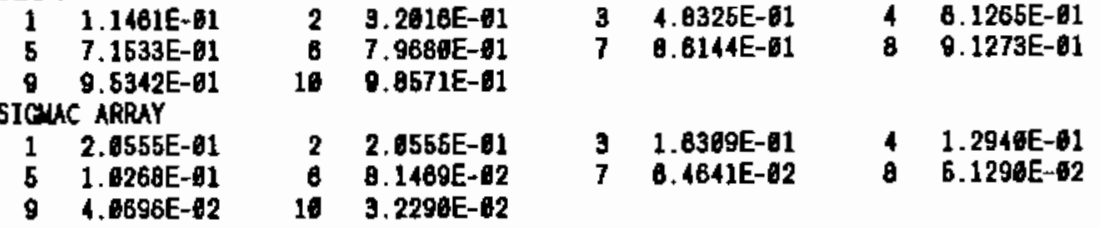

9 4. $6696 \mathrm{E}-\mathrm{t2}$

- $3.2298 \mathrm{E}-02$

********* OUTPUT FROU OPTIUIZATION PROCEXRE *********

OPTIUIZINO ON IIAD DIRECTION AND STABILITY

*** WARNING *** MXILW ITERATION LIUIT ENCOUNTERED

CHECK DIWUX TD DETERUINE IF EXCESSIVE LOCN DIVERGEMCES REUAN

N, R-CNLC, R-OBS, SP-CALC, SP-OBS, HEICHT ACL

$1 \quad 1.0008 \quad 1.0800 \quad 18.3090 \quad 18.360014 .0200$

$\begin{array}{llllll}2 & 0.9699 & 0.9508 & 17.6847 & 17.4606 & 14.0280\end{array}$

$\begin{array}{llllll}3 & 0.7668 & 0.7322 & 14.0285 & 13.4068 & 14.0286\end{array}$

$\begin{array}{llllll}4 & 6.8671 & 0.7322 & 14.7781 & 13.4800 & 14.0280 \\ 5 & 0.7341 & 0.6339 & 13.4335 & 11.8300 & 14.6200\end{array}$

$\begin{array}{llllll}B & 0.6807 & 0.6339 & 12.4559 & 11.6060 & 14.0209\end{array}$

$\begin{array}{llllll}8 & 0.6667 & .8831 & 12.2065 & 12.5609 & 14.0200 \\ 8 & 0.7168 & .8612 & 13.1024 & 12.1690 & 14.0209\end{array}$

IDR $=240.09$ BETA $=0.1429 \mathrm{TV}=1.0000 \mathrm{OF}=6.52892 \mathrm{E}-01$ ICDUNT $=28$

LINEAR SCALE FACTOR =

*** MARING *** WXILW ITERATION LIMIT EHCOUNTERED

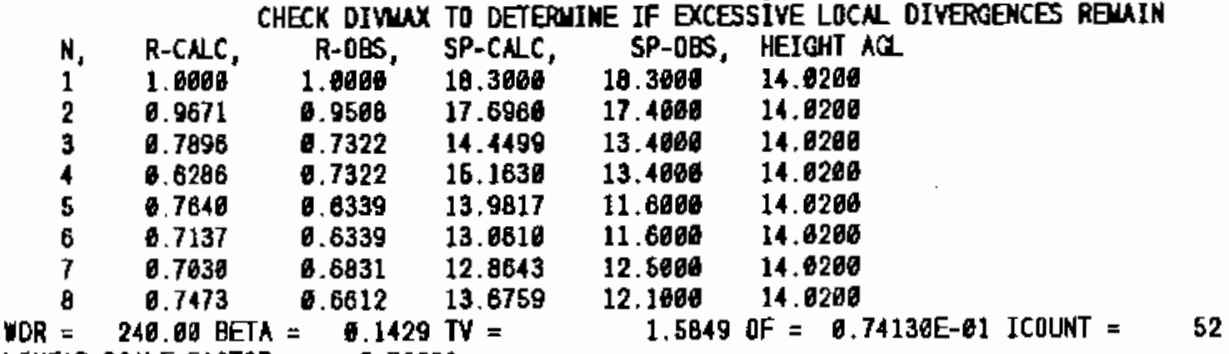
LINEAR SCALE FACTOR $=0.78291$

*** *ARNING *** WXIN ITERATION LIUIT ENCQLWTERED

CHECK DIVMAX TO DETERUINE IF EXCESSIYE LOCAL DIYERGENCES REMAIN

\begin{tabular}{|c|c|c|c|c|}
\hline $\begin{array}{ll}\text { N, } & \text { R-CALC, } \\
1 & 1.6960 \\
2 & 0.9539 \\
3 & 6.7363 \\
4 & 0.7760 \\
5 & 0.6994 \\
6 & 0.6165 \\
7 & 0.6268 \\
8 & 0.6822\end{array}$ & $\begin{array}{r}\text { R-0BS, } \\
1.0006 \\
0.9586 \\
0.7322 \\
0.7322 \\
0.6339 \\
0.6339 \\
0.6831 \\
0.6612\end{array}$ & $\begin{array}{l}\text { SP-CNLC, } \\
18.36869 \\
17.4559 \\
13.3642 \\
14.2961 \\
12.7996 \\
11.7266 \\
11.4764 \\
12.4643\end{array}$ & $\begin{array}{l}\text { SP-OBS, } \\
18.3000 \\
17.4009 \\
13.4000 \\
13.4000 \\
11.6080 \\
11.6090 \\
12.5900 \\
12.1000\end{array}$ & $\begin{array}{l}\text { HEIGHT AC } \\
14.6260 \\
14.6260 \\
14.6200 \\
14.6260 \\
14.6260 \\
14.6286 \\
14.6260 \\
14.6260\end{array}$ \\
\hline
\end{tabular}

$\mathrm{NDR}=248.00 \mathrm{BET}=0.0612 \mathrm{TV}=$

6318 OF $=0.35127 \mathrm{E}-61$ ICGUNT $=78$ 
*** MARNING *** MAXILM ITERATION LIUIT ENCOUNTERED,

CHECX DIVUX TD DETERUINE IF EXCESSIVE LOCN DIVERGEHCES REMIN

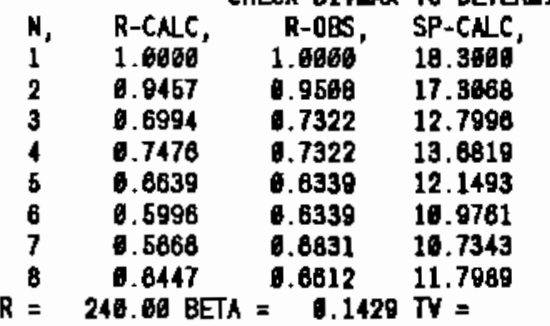

SP-OBS, HEIGHT AC

14.0200

14.0200

14.460014 .0280

$11.8809 \quad 14.0200$

1.000014 .6200

$12.5000 \quad 14.0206$

0.3901 OF $=\$ .49286 E-01$ ICOWN $=104$

LINEAR SCNE FACTOR $=8.69951$

** TARNING **" MAXIMY ITERATION LIVIT EHCOUHTERED,

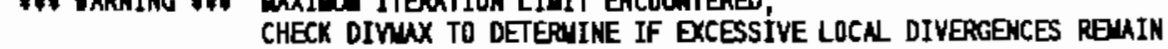

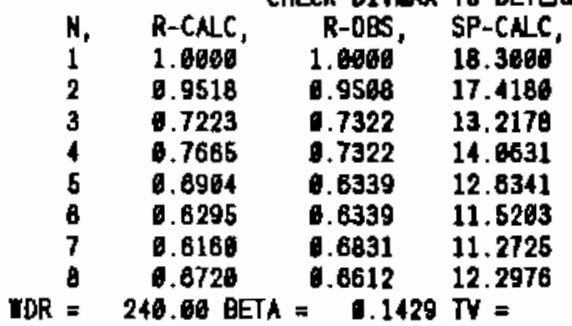

SP-OBS, HEIGHT ACL

LINEAR SCALE FACTOR $=0.71210$

** IARHING *** WAXILY ITERATION LIUIT ENCDUNTERED,

CHECK DIWUX TO DETERIINE IF EXCESSIVE LOCN DIVERGENES REMIN

N, R-CALC, R-OBS, SP-CALC, SP-OBS, HEIGHT RC

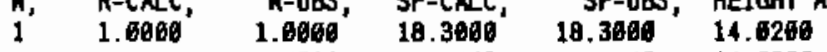

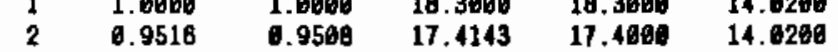

$\begin{array}{llllll}2 & .9516 & .9508 & 17.4143 & 17.4000 & 14.6280 \\ 3 & 0.7214 & 6.7322 & 13.2023 & 13.4006 & 14.0200\end{array}$

$\begin{array}{llllll}4 & 0.7678 & 0.7322 & 14.8573 & 13.4086 & 14.0206\end{array}$

$\begin{array}{llllll}5 & 0.6894 & 12.6339 & 12.6160 & 11.6800 & 14.0266\end{array}$

$\begin{array}{llllll}6 & 6.6285 & 0.6339 & 11.5017 & 11.6809 & 14.6260\end{array}$

$\begin{array}{llllll}7 & 0.6150 & 0.6631 & 11.2538 & 12.5060 & 14.6280 \\ 6 & 0.6713 & 0.6612 & 12.2848 & 12.1068 & 14.0208\end{array}$

YDR $=246.66$ BETA $=0.1429 \mathrm{TV}=0.5408 \mathrm{OF}=0.33966 \mathrm{E}-61$ ICOUNT $=156$

LINEAR SCALE FACTOR $=\$ .71139$

*** WARNIKG *** WAXIMY ITERATION LIUIT ENCOUNTERED

WAXILE ITERATION LIVIT ENCOUNTERES
CHECK DIVUAX TO DETERUINE IF EXCESSIVE LOCAL
R-DBS, SP-CALC, SP-DBS، HEIGHT AC.

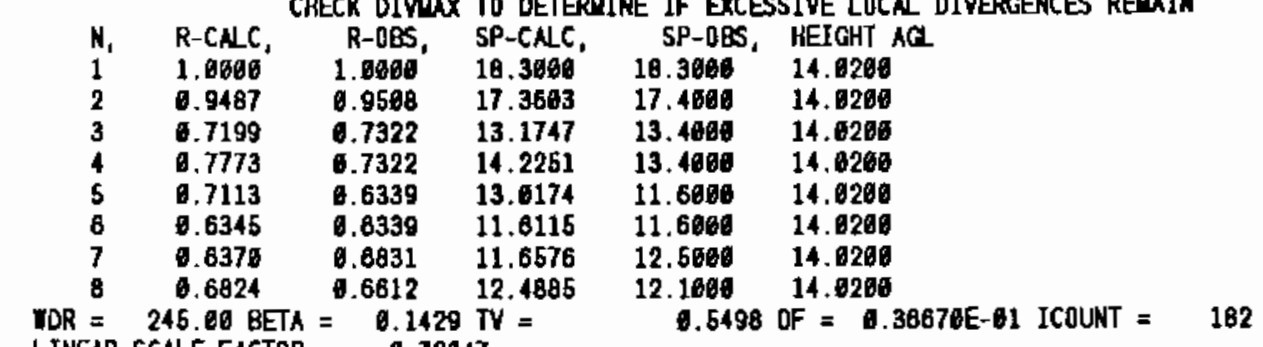

LINEAR SCALE FACTOR $=0.12647$ 
*** MARHIKG *** MAXIMN ITERATION LIUIT ENCOUNTERED,

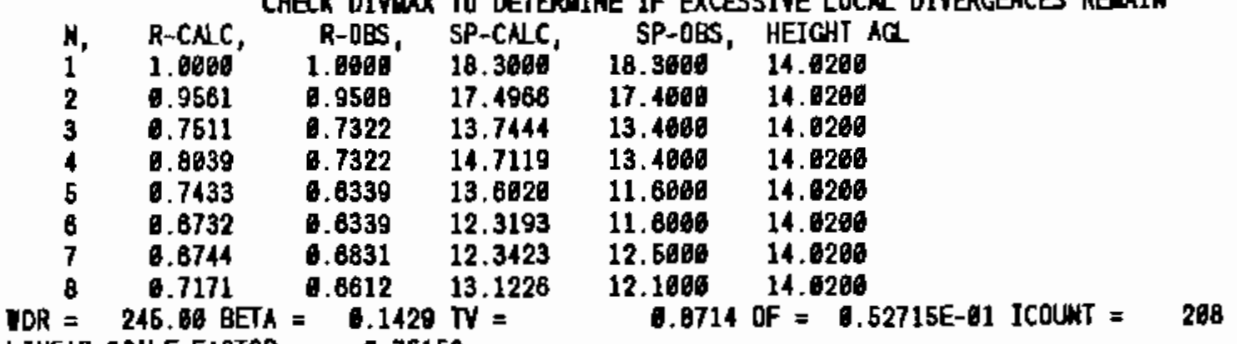

LINEAR SCNE FACTOR $=0.75153$

*** WARNING *** WXIUM ITERATION LIUIT ENCDUNTERED

CHECK DIVUX TO DETERNIHE IF EXCESSIVE LOCAL DIVERGEACES REMIN

\begin{tabular}{|c|c|c|c|}
\hline $\begin{array}{l}3 \\
4 \\
6 \\
8 \\
7 \\
8\end{array}$ & $\begin{array}{l}\text { R-CNC, } \\
1.0609 \\
6.9494 \\
6.6078 \\
6.7492 \\
6.6766 \\
.5936 \\
0.5991 \\
.6451\end{array}$ & $\begin{array}{c}\text { R-0BS, } \\
1.66896 \\
0.9588 \\
0.7322 \\
0.7322 \\
.6339 \\
0.6339 \\
0.6831 \\
6.6612\end{array}$ & $\begin{array}{l}\text { SP-CNLC } \\
10.3686 \\
17.2096 \\
12.6837 \\
13.7111 \\
12.3821 \\
19.8523 \\
19.9639 \\
11.8045\end{array}$ \\
\hline
\end{tabular}

WRR $=245 . B Q \mathrm{BETA}=0.1429 \mathrm{TV}$

LINEAR SCALE FACTOR =

** YARNING *** MXILW ITERATION LIUIT ENCOUNTERED

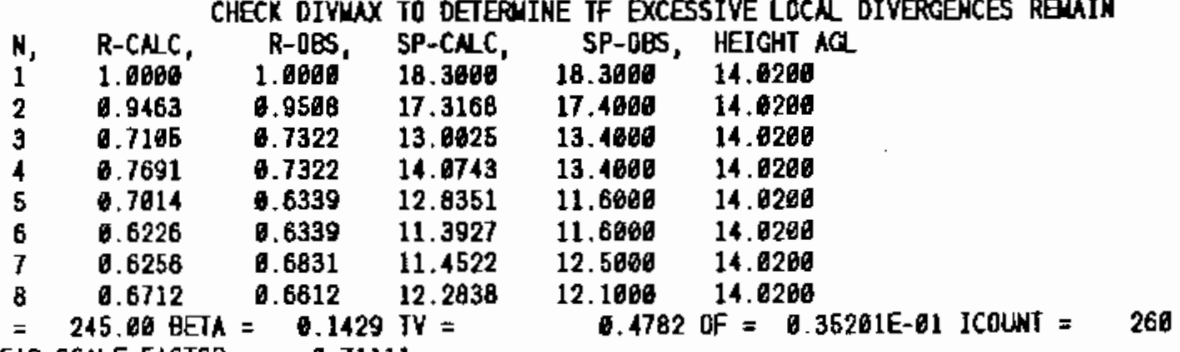

LINEAR SCALE FACTOR = 0.71111

*** WARNING *** WAXINYM ITERATION LIMIT EHCOUNTERED

N, R-CNC, R-OBS, SP-CNC, SP-OBS, HEIGHT AC

$\begin{array}{llllll}1 & 1.0606 & 1.0060 & 18.3860 & 18.3806 & 14.6286\end{array}$

$\begin{array}{llllll}2 & 0.9460 & 0.9568 & 17.3169 & 17.4068 & 14.0260 \\ 4 & 0.7091 & 0.7322 & 12.9769 & 13.4063 & 14.6260\end{array}$

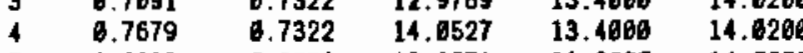

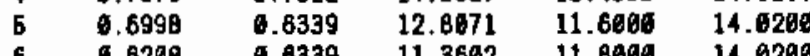

$\begin{array}{llllll}6 & 6.6208 & 0.8339 & 11.3682 & 11.8 B 00 & 14.0200\end{array}$

$\begin{array}{llllll}7 & 0.6241 & 0.6831 & 11.4216 & 12.5000 & 14.0200 \\ B & 0.6699 & 0.6612 & 12.2590 & 12.1000 & 14.0200\end{array}$

WDR $=245.06$ BET $=6.1429 \mathrm{TV}=\quad 6.4693$ OF $=0.36189 \mathrm{BE}-61 \mathrm{ICOUNT}=268$

LINEAR SCALE FACTOR $=0.76996$ 
*** UARNING *** UAXILN ITERATION LIUIT ENCOUNTERED,

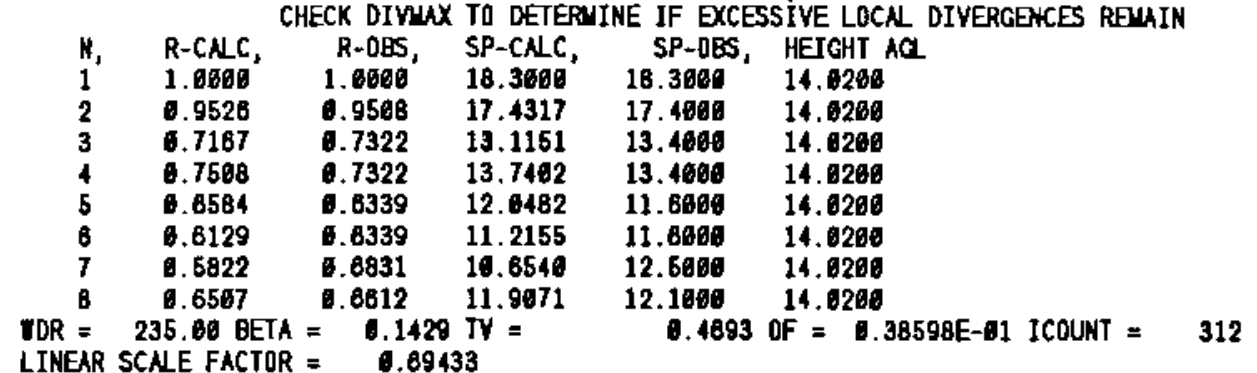

LTNEAR SCALE FACTOR =

CHECX DIVUXX TO DETERUINE IF EXCESSIVE LOCN DIVERGENES REUIN

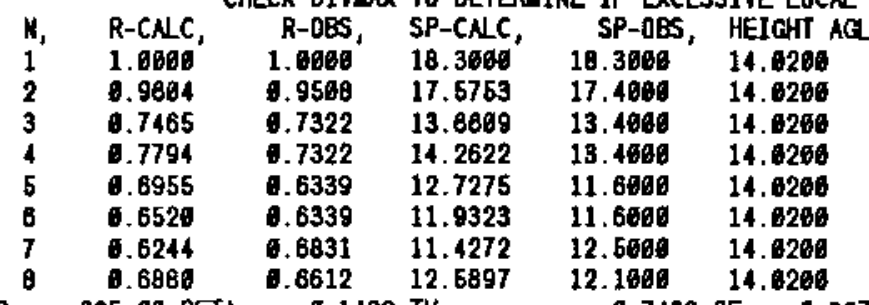

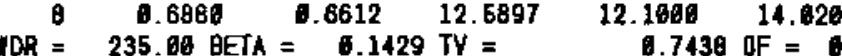

.7438 OF $=36732 \mathrm{E}-81$ ICOUNT $=338$

*** WARNING ** WXXINA ITERATION LINIT ENCOUNTERED

CHECK DIVUX TO DETEPUINE IF EXCESSIVE LOCN DIVERGENCES REUATN

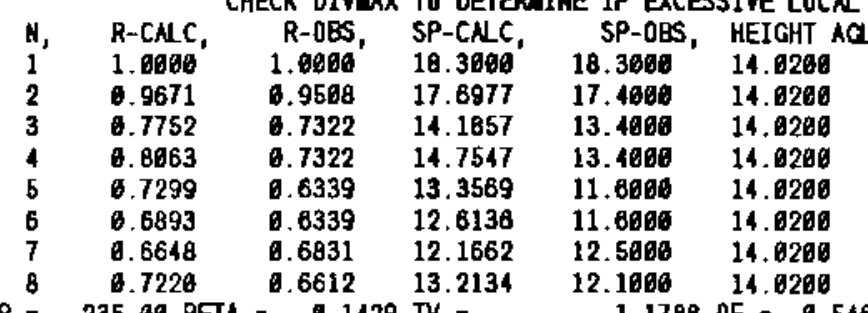

YOR $=235.86$ BETA $=0.1429 \mathrm{TV}=\quad 1.1788$ OF $=0.54666 \mathrm{E}-61 \mathrm{ICOUNT}=364$

LINEAR SCALE FACTOR $=\emptyset .75810$

*** MARNING *** WAXILW ITERATION LIHIT EXCQUNTERED

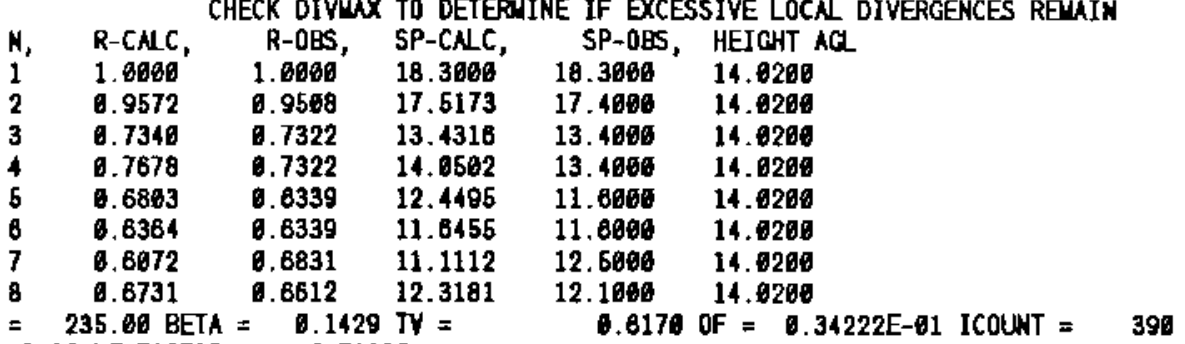

$235.60 \mathrm{BETA}=0.1429 \mathrm{TV}=$ 
*** WARYING *** MAXINU ITERATION LIMIT ENCOUNTERED,

CHECK DIVWX TO DETERUINE IF EXCESSIVE LDCN DIVERGENCES REMAIM

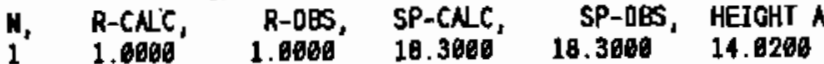

R-OBS, SP-CNC, SP-DES, HEIGHT AC

$\begin{array}{llllll}2 & 0.9571 & 0.9508 & 17.5142 & 17.4908 & 14.0200\end{array}$

$\begin{array}{llllll}3 & 0.7335 & 0.7322 & 13.4233 & 13.4008 & 14.0209\end{array}$

$\begin{array}{llllll}4 & 6.7872 & 0.7322 & 14.0398 & 13.4609 & 14.0206 \\ 5 & 0.6797 & 0.6339 & 12.4385 & 11.8600 & 14.0200\end{array}$

8 $\quad 0.6354 \quad 6.6339 \quad 11.6271 \quad 11.6608 \quad 14.0200$

$\begin{array}{llllll}7 & 0.6062 & 0.6831 & 11.6936 & 12.5060 & 14.6209\end{array}$

$\begin{array}{llllll}8 & 0.8722 & 0.6812 & 12.3685 & 12.1068 & 14.0209\end{array}$

IDR $=235.60 \mathrm{BETA}=0.1429 \mathrm{TV}=$

INEAR SCALE FACTOR =

4* IARNINO *** WAXIMN ITERATION LIUIT EMCOUWTERED,

CHECK OIVUX TO DETERIIIE IF EXESSIVE LOCN DIVERGENCES REMIN

H, R-CNC, R-OBS, SP-CNC, SP-OBS, HEIGHT AC

\begin{tabular}{|c|c|c|c|}
\hline $\begin{array}{l}1.0800 \\
0.9545 \\
0.7298 \\
0.7718 \\
.6912 \\
. .8363 \\
.6178 \\
.8767\end{array}$ & $\begin{array}{l}1.6009 \\
0.9508 \\
6.7322 \\
0.7322 \\
0.6339 \\
0.6339 \\
0.6831 \\
0.6812\end{array}$ & $\begin{array}{l}18.3066 \\
17.4687 \\
13.3522 \\
14.1269 \\
12.6489 \\
11.6442 \\
11.3951 \\
12.3845\end{array}$ & $\begin{array}{l}10.3000 \\
17.4000 \\
13.4606 \\
13.4000 \\
11.6000 \\
11.6008 \\
12.5000 \\
12.1000\end{array}$ \\
\hline
\end{tabular}

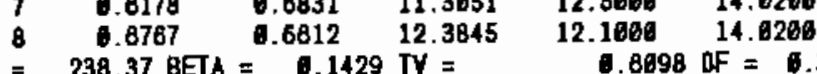

TOR $=238.37$ BET $=0.1429 \mathrm{TV}$

**A IARKING *\# MAXIMN ITERATION LIMIT ENCOURTERED,

CHECK DIVWX TD DETERYINE IF EXCESSIYE LOCN DIVERGENCES REMIN

$M$, R-CNC, R-DES, SP-CALC, SP-OBS, HEIGHT AG

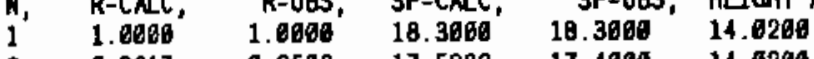

$\begin{array}{llllll}2 & 0.9817 & 0.9588 & 17.5989 & 17.4006 & 14.6206 \\ 3 & 0.7596 & 0.7322 & 13.8999 & 13.4006 & 14.6260\end{array}$

$\begin{array}{llllll}4 & 0.7987 & 0.7322 & 14.6160 & 13.4600 & 14.6200\end{array}$

$\begin{array}{llllll}5 & 0.7255 & 0.6339 & 13.2768 & 11.6080 & 14.0200\end{array}$

$\begin{array}{llllll}8 & 0.6746 & .6339 & 12.3453 & 11.6000 & 14.0200\end{array}$

$\begin{array}{llllll}7 & 0.6579 & 0.6831 & 12.0377 & 12.5000 & 14.6200 \\ 8 & 0.7119 & 0.6612 & 13.0276 & 12.1000 & 14.0200\end{array}$

$\mathrm{DDR}=236.37 \mathrm{GETA}=0.1429 \mathrm{TY}=$

6.9685 $\mathrm{OF}=0.48142 \mathrm{E}-61$ ICRUNT $=$

LINEAR SCALE FACTOR = 0.74798

*** YARNING *** WAXIMU ITERATION LIUIT ENCDUNTERED,

CHECK DIVWAX TO DETERUINE IF EXCESSIYE LOCA DIVERGENCES REMAIN

\begin{tabular}{|c|c|c|c|c|}
\hline $\begin{array}{l}\text { R-CALC, } \\
1.0806 \\
0.9482 \\
0.6984 \\
0.7425 \\
0.8538 \\
0.5953 \\
0.5763 \\
0.0388\end{array}$ & $\begin{array}{r}\text { R-0BS, } \\
1.0806 \\
0.958 B \\
0.7322 \\
9.7322 \\
0.8339 \\
6.6339 \\
0.8931 \\
0.8612\end{array}$ & $\begin{array}{l}\text { SP-CALC, } \\
18.3886 \\
17.3149 \\
12.7865 \\
13.5875 \\
11.9852 \\
19.8941 \\
18.5464 \\
11.6968\end{array}$ & $\begin{array}{l}\text { SP-OBS, } \\
18.3800 \\
17.4000 \\
13.4000 \\
13.4060 \\
11.6000 \\
11.6000 \\
12.5000 \\
12.1000\end{array}$ & $\begin{array}{l}14.6206 \\
14.6206 \\
14.6206 \\
14.6208 \\
14.6206 \\
14.6206\end{array}$ \\
\hline
\end{tabular}

WDR $=238.37 \mathrm{AETA}=0.1429 \mathrm{TV}=$

LINEAR SCNE FACTDR $=0.68465$

0.3848 DF $=8.43384 E-81$ ICOUNT $=$ 
*** WARHING *** MAXIMU ITERATION LIUIT ENCOLNTERED,

CHECK DIVUAX TO DETERUINE IF EXCESSIVE LOCN DIVERGEACES REUAIN

H. R-CNC, R-OBS, SP-CNC, SP-OBS, HEICHT AC

$1 \quad 1.0680$ 1.0086 $18.3060^{\circ} 18.3906$ 14.0200

$20.8566 \quad 0.7322 \quad 13.2971$

$\begin{array}{llllll}3 & 0.7266 & 0.7322 & 13.2971 & 13.4606 & 14.0268 \\ 6 & 0.7687 & 0.7322 & 14.0668 & 13.4909 & 14.8209\end{array}$

$\begin{array}{llllll}6 & 6.6877 & 0.6339 & 12.5841 & 11.8000 & 14.0200\end{array}$

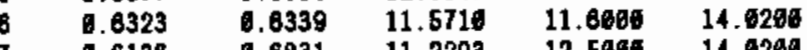

\begin{tabular}{llllll}
7 & 0.6136 & 0.6831 & 11.2293 & 12.5668 & 14.6260 \\
\hline & 0.6728 & .6612 & 12.3120 & 12.1698 & 14.0200
\end{tabular}

WDR $=238.37$ BETA $=0.1429 \mathrm{TV}=\quad 0.5016$ OF $=0.33943 \mathrm{E}-01$ ICOLWT $=620$

LINEAR SCNE FACTOR $=$ T.71288

*** MARHING ** MXXIMN ITERATION LIMIT ENCOLATERED

CHECK DIVUXX TO DETERUINE IF EXCESSIVE LOCN DIVERGENCES REMIM

$N$ R-CNC, R-OBS, SP CAL, SP-OBS, HEICHT AC

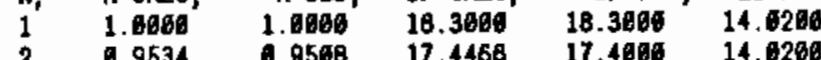

$13.4006 \quad 14.6206$

$\begin{array}{llll}0.7322 & 14.6784 \quad 13.4006 & 14.0260\end{array}$

$\begin{array}{llllll}6 & 0.6325 & 6.6339 & 11.5749 & 11.6680 & 14.6200\end{array}$

$7 \quad 0.6153 \quad 0.6831 \quad 11.2591 \quad 12.5800114 .8200$

$\begin{array}{lllll}0.6737 & 0.6812 & 12.3281 & 12.1600 & 14.0280\end{array}$

DINEAR SCAE FACTOR $=0.1429 \mathrm{TV}=$

** VARNING ** WAXILN ITERATION LIUTT ENCOUNTERED

CHECK DIVUNX TO DETERMINE IF EXCESSIVE LOCN DIVERGEKCES REUAIN

$N$ R-CALC, R-OBS, SP-CNC, SP-OBS, HEIGHT AGL

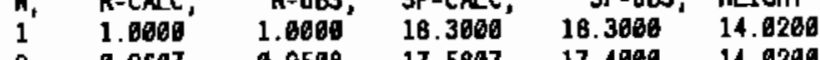

$\begin{array}{llllll}2 & 0.9607 & .9508 & 17.5867 & 17.4098 & 14.0200\end{array}$

$\begin{array}{llllll}3 & 0.7562 & 6.7322 & 13.8388 & 13.4900 & 14.0290 \\ 4 & 0.7968 & 0.7322 & 14.5773 & 13.4960 & 14.0200\end{array}$

$\begin{array}{llllll}5 & 0.7238 & 0.6339 & 13.2413 & 11.6800 & 14.0206\end{array}$

$\begin{array}{llllll}8 & 6.6716 & 0.6339 & 12.2861 & 11.6806 & 14.0206\end{array}$

$\begin{array}{lllll}0.7091 \quad 0.8 B 12 & 12.9766 & 12.1006 & 14.0209\end{array}$

MOR $=238.82$ BET $=0.1429 \mathrm{TV}=\quad 0.9218$ OF $=0.48565 E-01$ ICOUNT $=572$

LINEAR SCALE FACTOR $=0.74529$

MXIMN ITERATION LIHIT ENCOUNTERED

CHECK DIVWX TO DETERUINE IF EXCESSIVE LDCAL DIVERGEACES REMIN

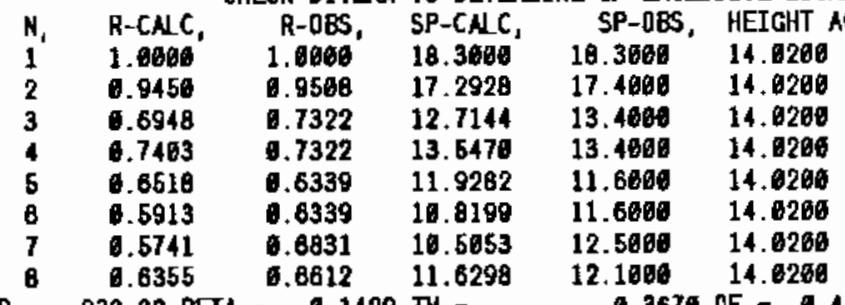

WDR $=238.82$ BETA $=0.1429 \mathrm{TV}=0.3670 \mathrm{OF}=0.44976 \mathrm{E}-61$ ICOLNT $=59$

LIMEAR SCNLE FACTOR $=\boldsymbol{0 . 6 8 2 1 4}$ 
*** WARNING *** MAXILM ITERATION LIUIT ENCOLWTERED

CHECK DIVIAX TO DETERNINE IF EXCESSIVE LOCAL DIVERGEACES REMAIN

N, R-CNC, R-OBS, SP-CALC, SP-OBS, HEICHT ACL

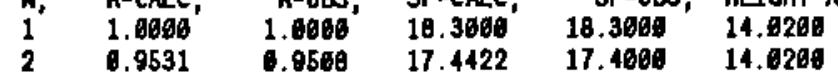

$\begin{array}{llllll}2 & 0.9531 & .8589 & 17.4422 & 17.4609 & 14.0209 \\ 3 & 0.7252 & .7322 & 13.2718 & 13.4669 & 14.6209\end{array}$

$\begin{array}{llllll}4 & 0.7684 & 0.7322 & 14.0624 & 13.4000 & 14.0200\end{array}$

$\begin{array}{llllll}5 & 0.6882 & 0.6339 & 12.5846 & 11.6868 & 14.6206\end{array}$

$\begin{array}{llllll}6 & 0.6313 & 0.6339 & 11.5525 & 11.6030 & 14.6260\end{array}$

B $\quad 0.8 \mathrm{B31} \quad 11.2365 \quad 12.5869 \quad 14.6280$

TDR $=238.82$ BETA $=0.1429 \mathrm{TV}=0.673$ OF $=0.33934 \mathrm{E}-01$ ICOUNT $=824$

LINEAR SCAE FACTOR $=$

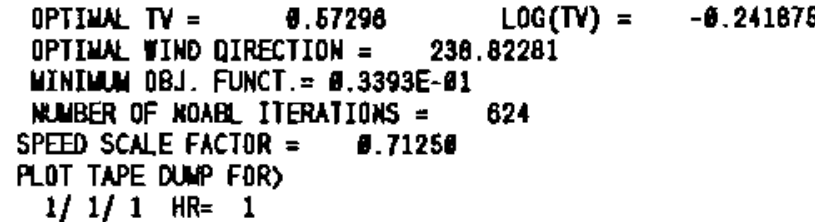


APPENDIX $F$

SUPPLEMENTARY SOFTWARE 
APPENDIX F

\section{SUPPLEMENTARY SOFTWARE}

The model produces a binary file that contains the terrain data and the final, calculated winds. The supplementary software listed here takes that binary file and makes a contour plot of the terrain and wind speed. In this way the output of a model run can be interpreted.

The software consists of three files, listed in this order:

1) HCONPLOT.FOR

2) COMMONJ.INC

3) GETSPEED.FOR

File 2, COMMONJ.INC, contains a common block that is shared both by the model and the supplementary software. After compilation, this software must be linked with the DISSPLA ${ }^{(a)}$ library, which contains the graphics subroutines used by this software. If this library is not available, other plotting commands must be substituted for the DISSPLA commands.

(a) DISSPLA is a proprietary software product of Integrated Software systems Corporation. 

1: PREGRN HCONPLDT

2: C PROGRAN TO CONTQUR THE INDSPEED AT A SPECIFIC HEGHT (AG)

3: C CAN OPTIONALY CONTOUR THE TERAIA

4: comon work (16906)

5: INCLUDE 'COMONA.IH/LIST'

8: CHARACTER*40 INPUT FILE

7: CHARACTER 1 ANS

COYHOK/CNB/SPED1 (18:9) IHPUT FILE

$c$ CaLnN/ARRAY/ zant $(40,46), x \operatorname{con}(1806), y \operatorname{con}(1606), z \operatorname{con}(1606)$

2:

C

14:

:

B: $C$

1011

:

WRITE(* '( ${ }^{\prime \prime}$ HECHT (ACL) FOR SPEED CONTDURS? ")')

$\operatorname{READ}(*, *) H$

WRITE(*, (" RATIOS??? (Y/N)" ')')

READ (*,' (A)') ANS

WRITE $(*, 1011)$

FORUT(' ENTER SPEED CDNTQUR INTERVA (U/S) CR RATIO INTERVAL')

READ $(*, *)$ SPEED_INT

URITE (*, ' (" EITER TERRAIN CONTOUR INTERYL (U) ' ')')

REND $(*, *)$ COXT_INT

C

TYPE *, 'EITER MOAQ IMPUT FILE:'

ACCEPT 101, INPST FILE

101 FORUT (A)

OPGIUAIT=10, KHEE=INPUT FILE, TYPE=' OLD', READDNLY,

- FORL='UFORMTIED'?

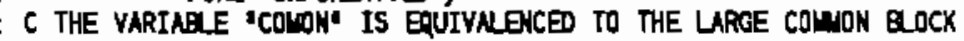

read (16) comon

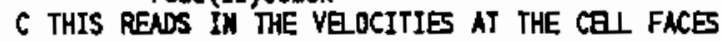

read(19) $u, Y$,

COSE(10)

call conprs

call pago $(8.5,11.6)$

C

$x a x i s=6.25$

$y 2 x i g=6.25$

C DIMEISIONS BF NODEING DOMAIN DOMAIM

$X L E N T H=(I W X * D X) / 1000$.

YENGTH=JWX:DY/1600.

IF (XLEIGTH. GT. MEHGTH) THEY

YAXIS=XAXIS YLENGTH/XLENOTH

QLSE

XXXIS-YAXIS*XLENGTH/RENGTH

ENDIF

CNL NDBRDR

call area2d(xaxis, yaxis)

CHL HEICHT (.25)

CNL INTAXS

call xnano('X (XY) \$',106)

Call ynano('Y (KM) 8', 100)

call xticks(5)

call yticks(b)

call graf $(0 ., 1$, XleiGTH, $6,1 .$, MEIGTH)

call frape

C COMTOUR THE TERRAIN

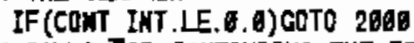

: C DISPLAY CNLS FOR CDNTOURIMG THE TERRAIN

call beomon (16098)

call bgnaat (inax, jarax)

63: C EXTRACT THE TERRIN DATA FROY THE COMNON BLOCK 


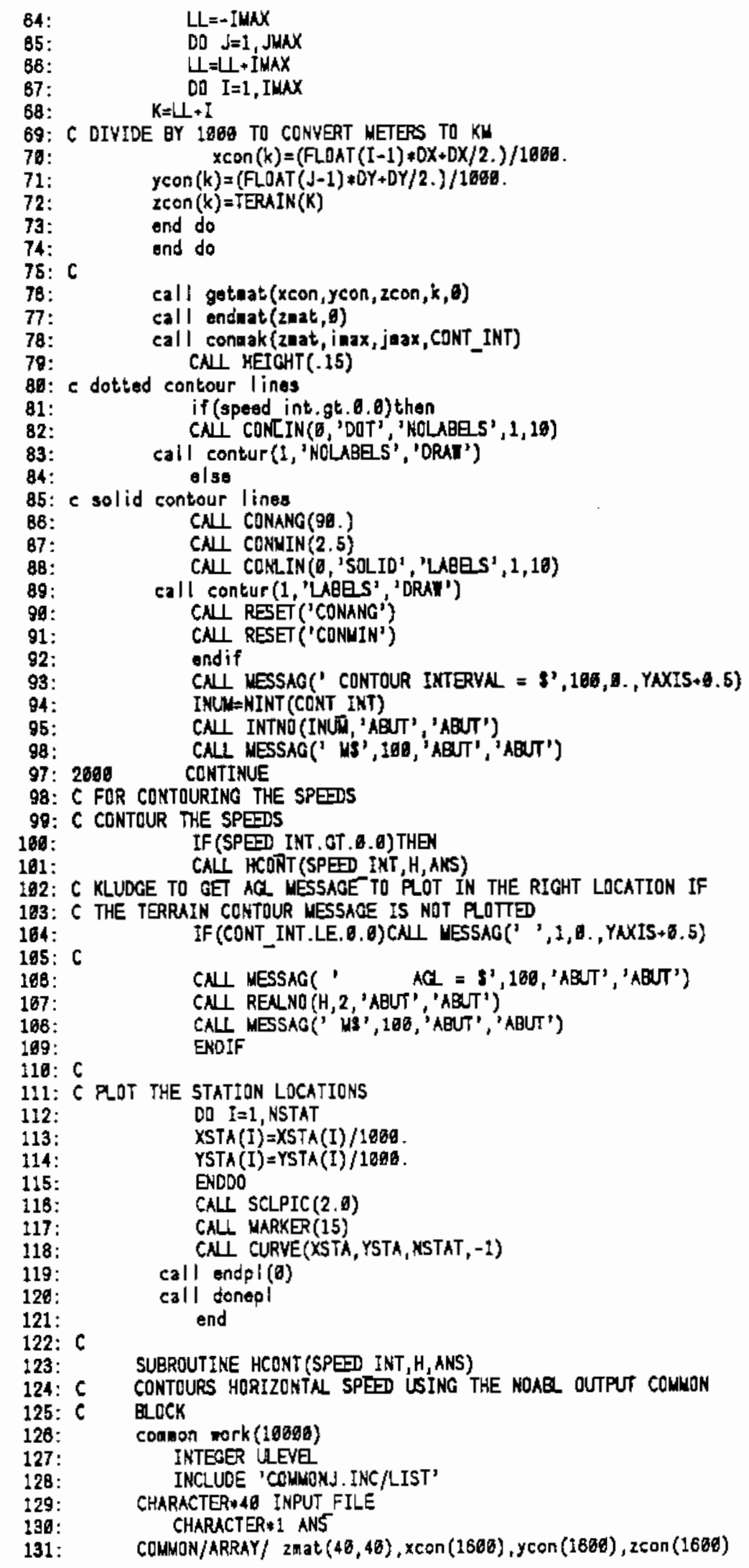




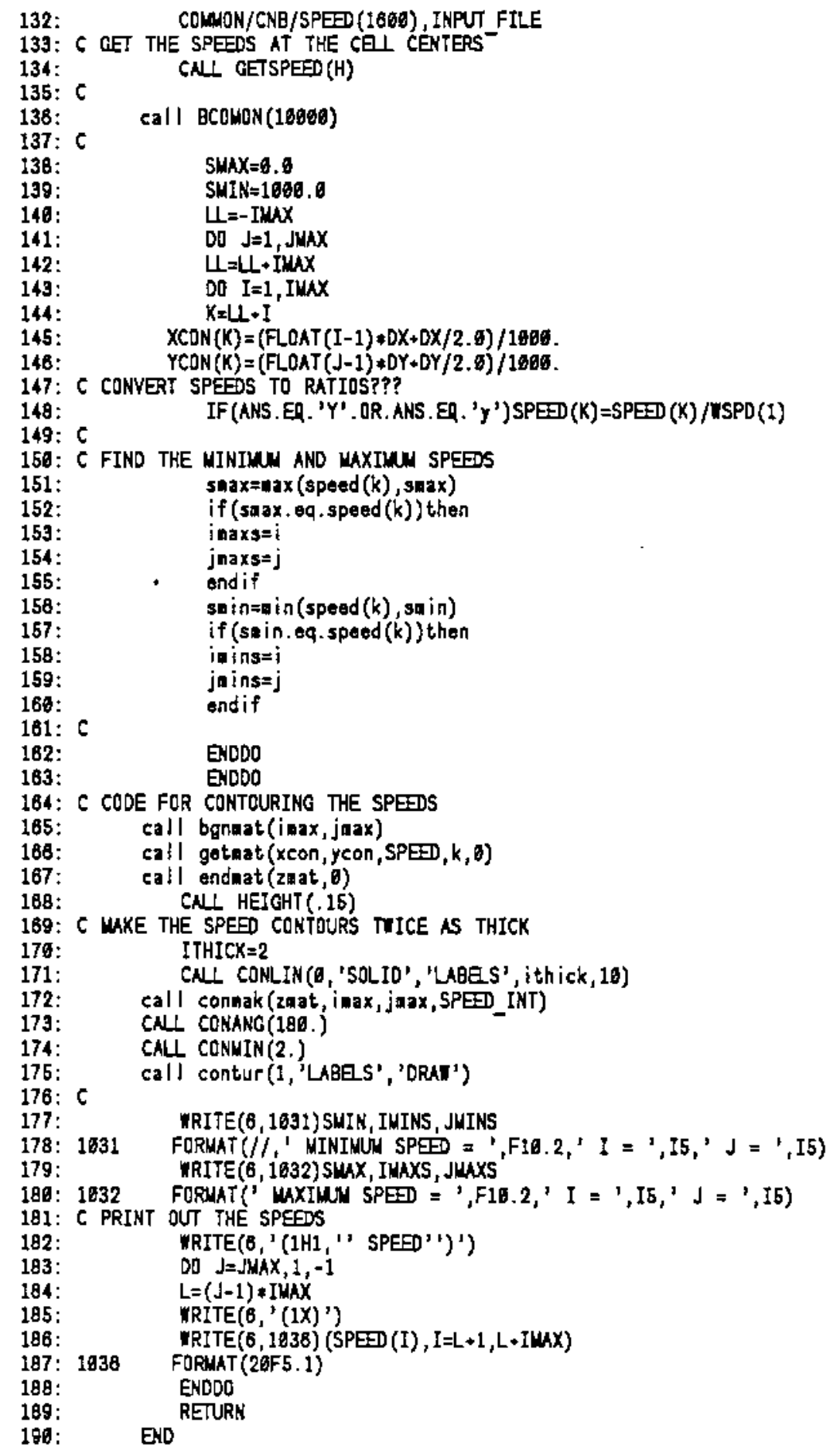


FILE: COMMONJ.INC

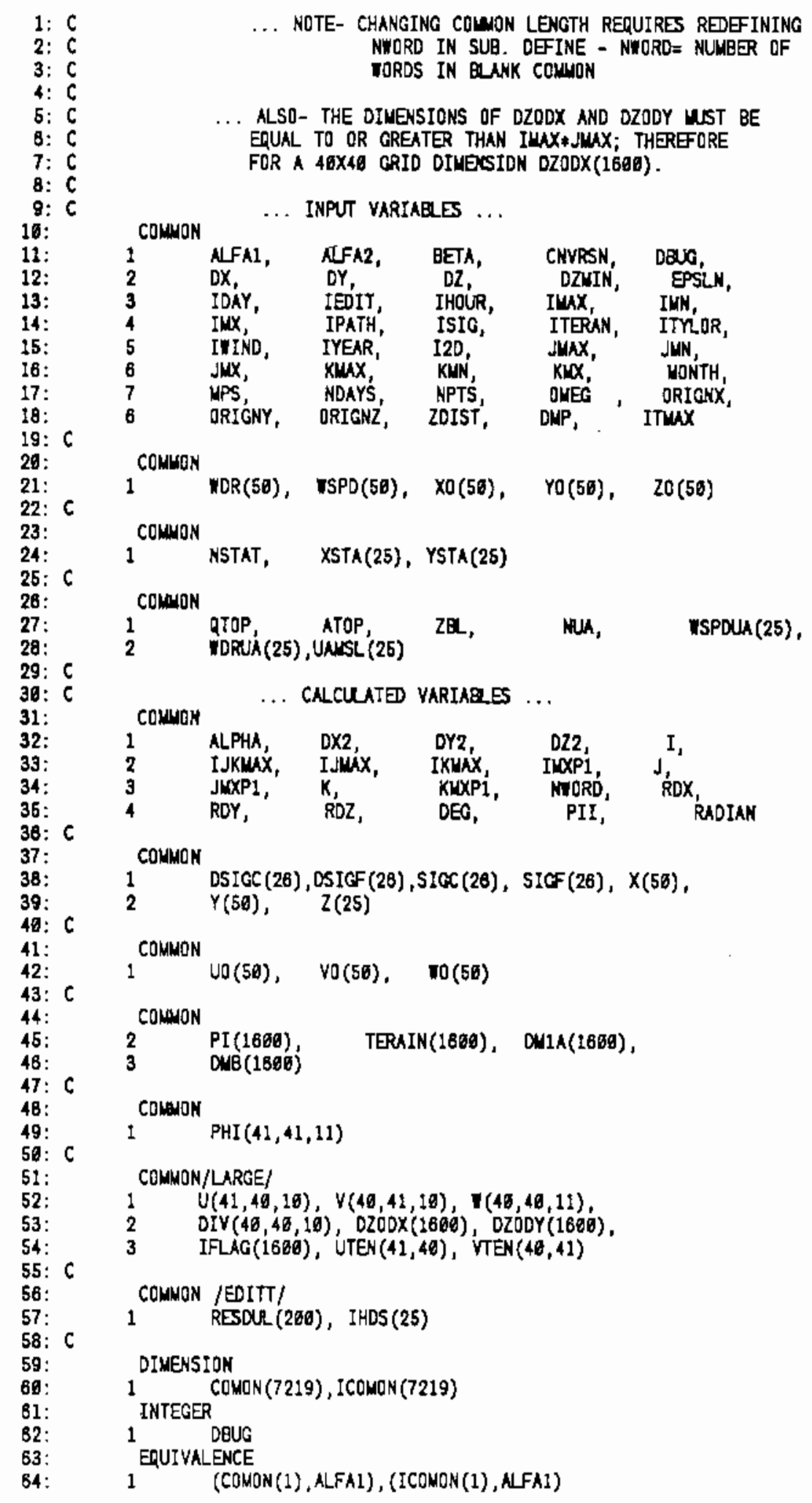


FILE： GETSPEED.FOR

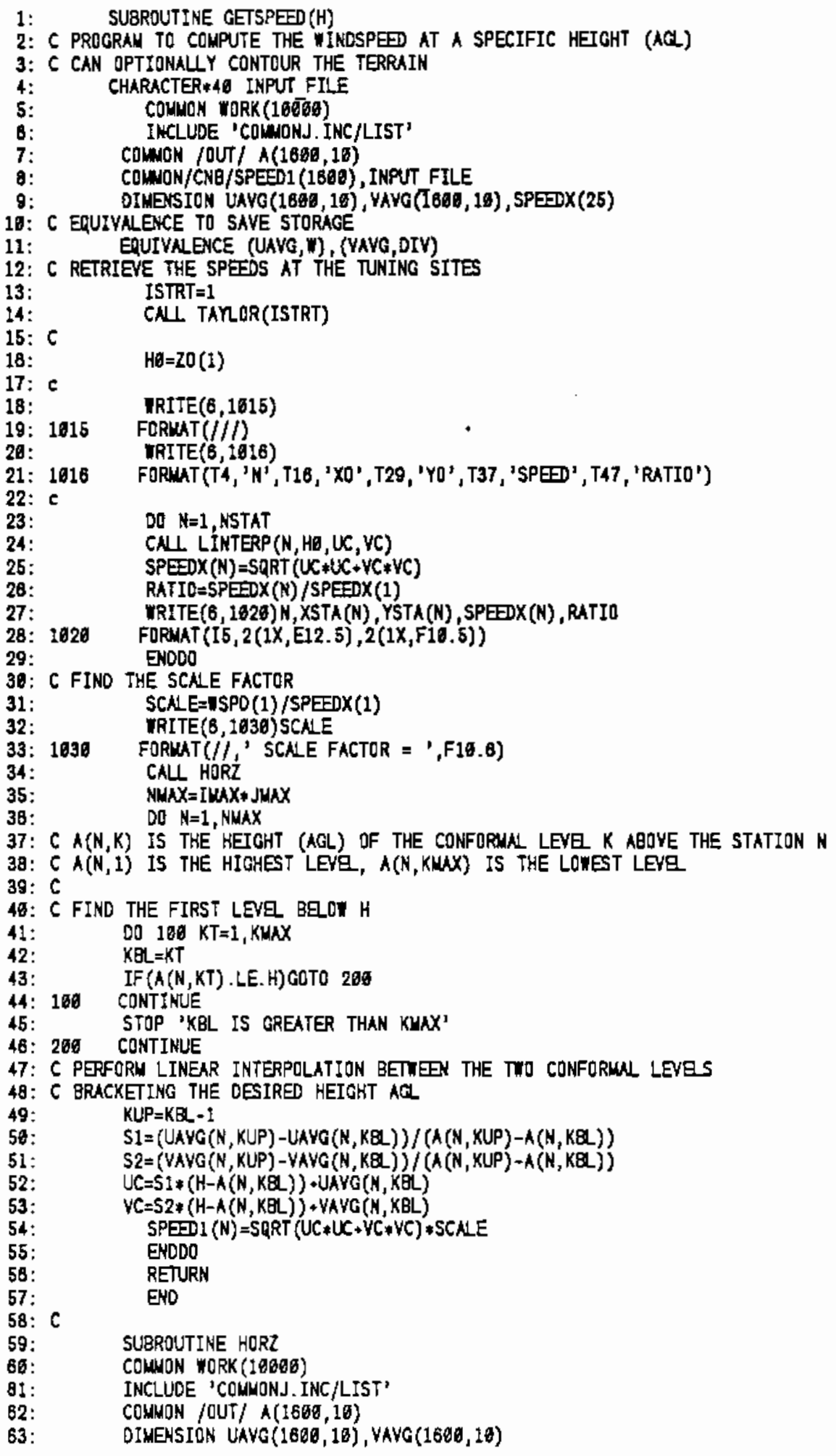




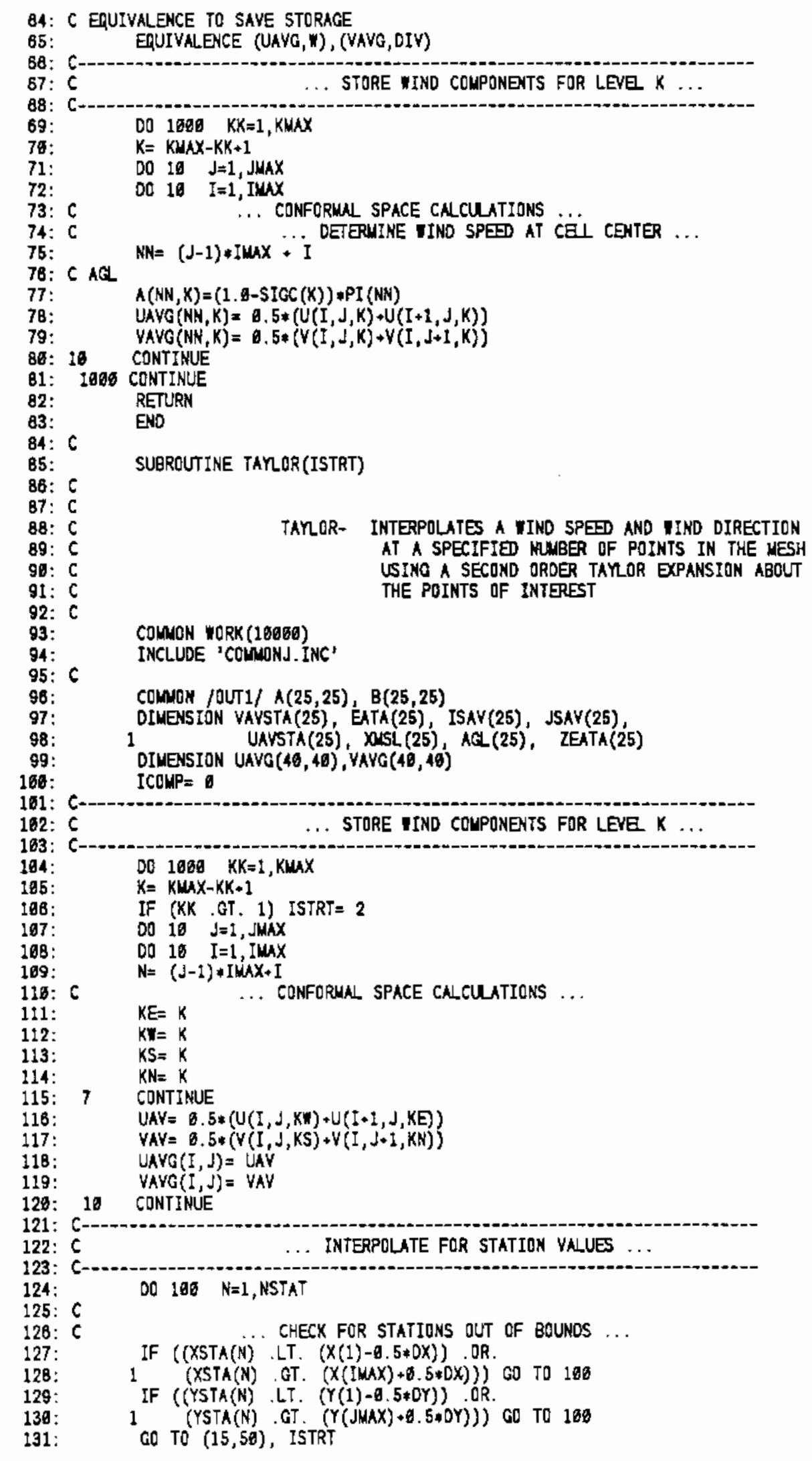




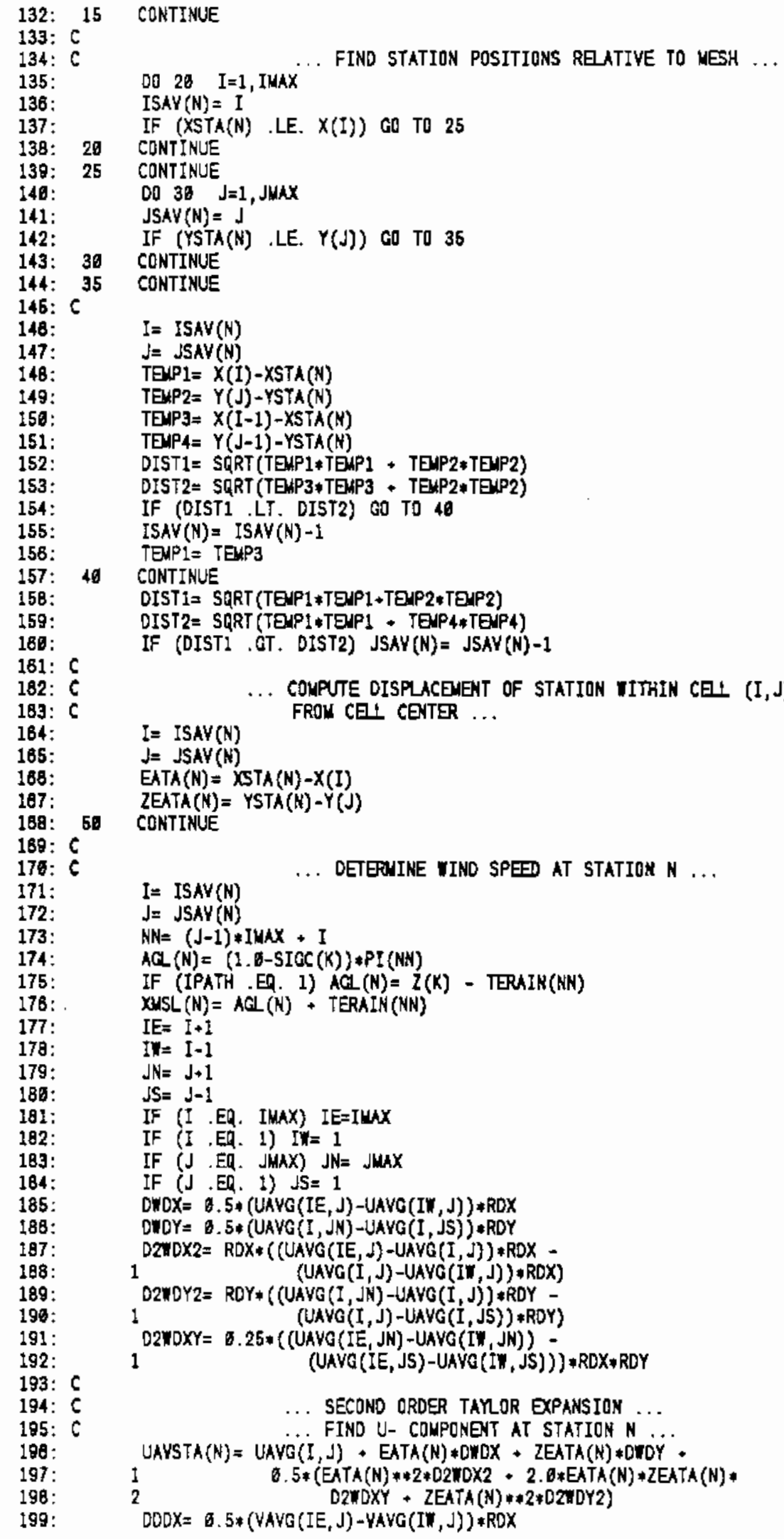

193: $C$

194: $\mathrm{C}$

105: $C$

198:

197:

198:

199:

$I=I S A V(N)$ .. DETEFINE IND SPEED AT STATIOM N ... $J=J S A Y(N)$ 


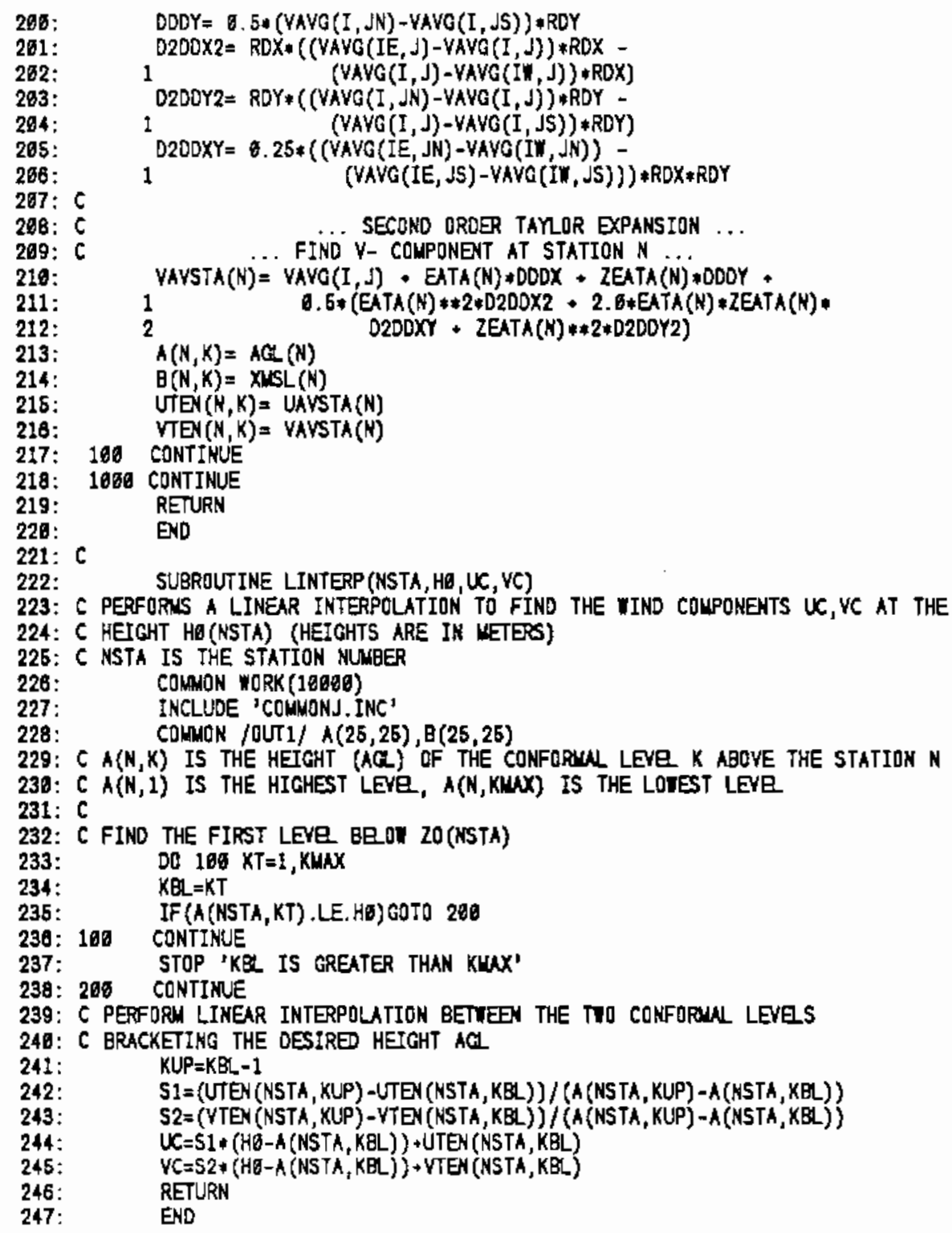




\section{APPENDIX G}

PRINTED OUTPUT FROM THE SUPPLEMENTARY SOFTWARE 


\section{APPENDIX G}

\section{PRINTED OUTPUT FROM THE SUPPLEMENTARY SOFTWARE}

The supplementary software produces both graphical and printed output. The printed output is shown here. The first page starts by listing the $x$ and $y$ coordinates of the tuning sites and the calculated speeds and ratios at these sites. This information is followed by the speed scale factor, which should be 1.0, and then the maximum and minimum speeds, and the horizontal grid point locations where these speeds occur.

The next pages list the final, calculated wind speeds at each horizontal grid point for the height specified in the input. These speeds are listed downwards, row by row, so that the first speed, $13.4 \mathrm{~m} / \mathrm{s}$, corresponds to the grid point $I=1, J=40$; the second speed, $12.2 \mathrm{~m} / \mathrm{s}$, corresponds to $I=2, J=40$, etc. This pattern continues until the lowest row of speeds has been printed; these are the speeds along the bottom edge of the modeled area.

The width of the paper does not allow all the speeds from one row of model grid potnts to be printed on one line. Because of this, the speeds from one row require two printed lines, one directiy below the other. Speeds from different rows are separated by a blank line. 
. 


\begin{tabular}{|c|c|c|c|c|}
\hline & $\times 0$ & Y & SPEED & RATIO \\
\hline & $0.10410 E+04$ & $0.59800 \mathrm{E}+83$ & 18.30000 & 1.80000 \\
\hline 2 & 6.11957E+04 & $0.53384 E+03$ & $\begin{array}{l}17.44162 \\
13.26912\end{array}$ & $\begin{array}{l}0.95309 \\
0.72599\end{array}$ \\
\hline & Q.B3463E+63 & $0.11845 E+04$ & $14.6617 !$ & 0.78840 \\
\hline & $0.16138 E+64$ & $0.13505 E+64$ & & 0.88798 \\
\hline & $0.15676 \mathrm{E}+04$ & $0.16152 \mathrm{E}+04$ & & \\
\hline & - $.96263 E+63$ & $0.18827 \mathrm{E}+04$ & & \\
\hline & $0.15824 E+64$ & $6.14175 E+64$ & 12.3 & .67247 \\
\hline
\end{tabular}

SCNE FACTOR $=1.080800$

$\begin{array}{rrrr}\text { MINIMY SPEE } & 9.3 B I= & 36 \mathrm{~J}= & 5\end{array}$

SPED

$\begin{array}{lllllllllllllllllllllllll}13.4 & 12.2 & 11.8 & 11.3 & 10.9 & 10.7 & 10.8 & 11.0 & 10.9 & 10.7 & 10.6 & 10.7 & 11.4 & 12.5 & 12.8 & 11.8 & 10.9 & 10.9 & 11.2 & 11.4\end{array}$

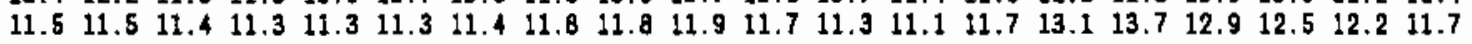

$\begin{array}{llllllllllllllllllll}14.8 & 13.0 & 12.1 & 11.5 & 11.2 & 11.2 & 11.2 & 11.1 & 10.9 & 16.7 & 10.4 & 16.1 & 16.5 & 11.9 & 13.2 & 12.9 & 11.7 & 11.2 & 11.8 & 11.8\end{array}$

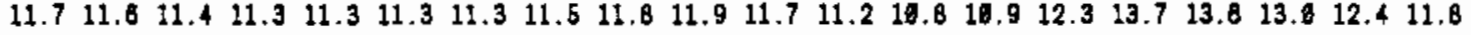

$\begin{array}{llllllllllllllllllll}15.5 & 13.8 & 12.8 & 12.2 & 11.7 & 11.4 & 11.3 & 11.1 & 11.0 & 10.9 & 10.6 & 10.2 & 10.0 & 10.8 & 12.5 & 13.3 & 12.8 & 11.9 & 12.1 & 12.4\end{array}$

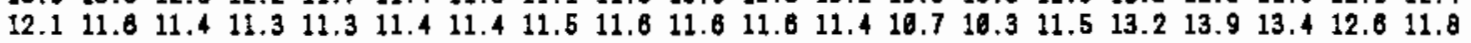

$\begin{array}{llllllllllllllllllllllllllll}15.8 & 14.3 & 13.4 & 12.8 & 12.2 & 11.8 & 11.8 & 11.4 & 11.2 & 11.1 & 11.6 & 10.6 & 10.1 & 16.1 & 11.1 & 12.3 & 12.8 & 12.7 & 12.9 & 13.1\end{array}$ $\begin{array}{llllllllllllllllllll}12.7 & 12.0 & 11.6 & 11.4 & 11.3 & 11.4 & 11.6 & 11.6 & 11.6 & 11.4 & 11.5 & 11.7 & 11.0 & 10.1 & 16.8 & 12.3 & 13.7 & 13.7 & 12.8 & 11.8\end{array}$

$\begin{array}{llllllllllllllllllllllllll}15.8 & 14.7 & 14.9 & 13.4 & 12.8 & 12.3 & 12.1 & 11.8 & 11.5 & 11.4 & 11.3 & 11.1 & 10.7 & 10.2 & 10.3 & 10.8 & 11.3 & 12.6 & 12.9 & 13.8\end{array}$ $\begin{array}{llllllllllllllllllll}13.5 & 12.7 & 11.9 & 11.8 & 11.5 & 11.5 & 11.6 & 11.8 & 11.8 & 11.8 & 11.7 & 12.0 & 11.5 & 10.3 & 10.6 & 11.4 & 13.0 & 13.7 & 13.1 & 11.9\end{array}$

$\begin{array}{lllllllllllllllllllllll}15.8 & 14.5 & 14.1 & 14.2 & 13.8 & 13.2 & 12.7 & 12.3 & 11.9 & 11.7 & 11.8 & 11.5 & 11.2 & 10.8 & 10.4 & 10.2 & 10.1 & 10.4 & 11.8 & 12.9\end{array}$

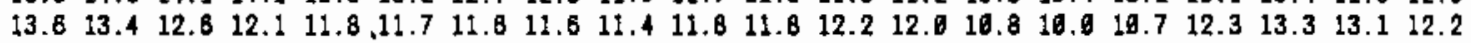

$\begin{array}{lllllllllllllllllllllll}16.1 & 13.9 & 13.1 & 13.2 & 13.7 & 13.9 & 13.5 & 12.8 & 12.3 & 12.1 & 11.8 & 11.7 & 11.5 & 11.1 & 10.6 & 10.4 & 10.6 & 9.8 & 10.2 & 11.3\end{array}$ $\begin{array}{llllllllllllllllllllllll}12.5 & 13.0 & 12.8 & 12.3 & 12.0 & 11.8 & 11.8 & 11.5 & 11.4 & 11.8 & 12.0 & 12.2 & 12.0 & 11.3 & 10.4 & 10.4 & 11.8 & 12.7 & 12.9 & 12.2\end{array}$

$\begin{array}{lllllllllllllllllllllll}16.4 & 15.3 & 14.6 & 13.2 & 12.8 & 13.9 & 13.6 & 13.3 & 12.4 & 12.2 & 12.2 & 12.6 & 11.7 & 11.2 & 10.8 & 19.8 & 16.4 & 10.2 & 19.1 & 10.5\end{array}$ $\begin{array}{lllllllllllllllllllll}11.3 & 11.9 & 12.1 & 12.0 & 11.8 & 11.8 & 11.4 & 11.2 & 11.2 & 11.7 & 12.2 & 12.3 & 11.9 & 11.4 & 19.8 & 10.6 & 11.1 & 12.9 & 12.5 & 12.1\end{array}$

$\begin{array}{llllllllllllllllllllllllllll}15.8 & 18.6 & 15.8 & 14.8 & 14.0 & 13.1 & 13.2 & 13.3 & 12.8 & 12.7 & 12.5 & 12.1 & 11.8 & 11.4 & 18.9 & 10.7 & 10.7 & 10.7 & 19.8 & 18.7\end{array}$

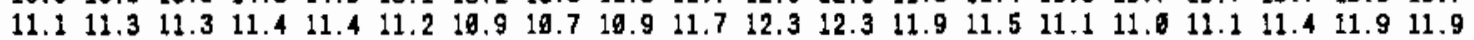

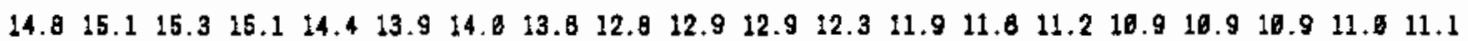

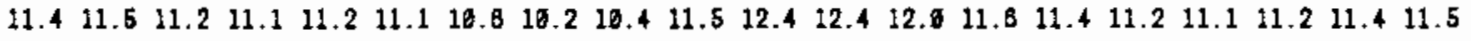

$\begin{array}{lllllllllllllllllllllllll}15.6 & 14.7 & 14.4 & 15.3 & 14.8 & 13.8 & 14.6 & 14.2 & 13.1 & 12.8 & 13.1 & 12.7 & 12.2 & 11.9 & 11.8 & 11.3 & 11.1 & 11.1 & 11.2 & 11.4\end{array}$

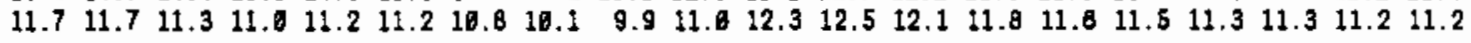

$\begin{array}{llllllllllllllllllllllll}14.8 & 14.7 & 14.0 & 15.1 & 15.5 & 14.3 & 13.6 & 14.1 & 13.7 & 13.0 & 13.0 & 13.0 & 12.8 & 12.3 & 12.1 & 11.9 & 11.6 & 11.4 & 11.5 & 12.9\end{array}$

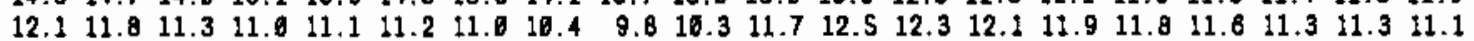

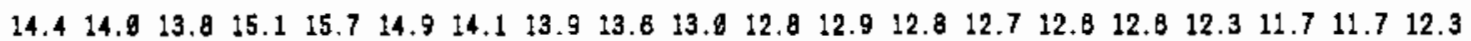
$\begin{array}{lllllllllllllllllllllll}12.5 & 11.9 & 11.4 & 11.1 & 11.1 & 11.2 & 11.2 & 18.8 & 18.1 & 9.9 & 10.8 & 12.0 & 12.2 & 12.2 & 12.9 & 11.9 & 11.8 & 11.6 & 11.4 & 11.1\end{array}$ 
$\begin{array}{lllllllllllllllllllllllllll}14.4 & 13.6 & 13.2 & 14.9 & 18.0 & 15.3 & 14.5 & 14.6 & 13.4 & 12.8 & 12.4 & 12.3 & 12.4 & 12.4 & 12.5 & 12.8 & 12.8 & 12.1 & 12.1 & 12.7\end{array}$

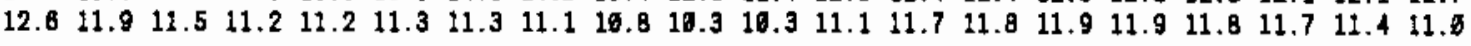

$\begin{array}{llllllllllllllllllllllllll}14.9 & 12.8 & 12.8 & 14.1 & 15.9 & 15.8 & 15.1 & 14.6 & 13.8 & 13.9 & 12.4 & 12.6 & 11.9 & 11.9 & 12.1 & 12.7 & 13.1 & 12.5 & 12.2 & 12.8\end{array}$

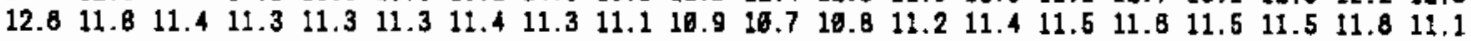

$\begin{array}{lllllllllllllllllllllllllllll}15.1 & 13.9 & 12.7 & 13.1 & 14.8 & 15.5 & 15.4 & 15.4 & 15.1 & 14.1 & 13.2 & 12.5 & 12.6 & 11.7 & 11.8 & 12.9 & 13.6 & 13.3 & 12.6 & 12.7\end{array}$

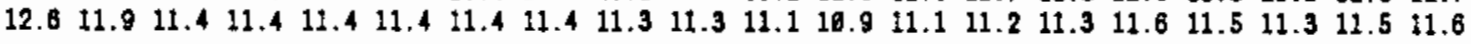

$\begin{array}{llllllllllllllllllllllllllll}15.0 & 14.9 & 14.0 & 13.4 & 13.7 & 14.1 & 14.5 & 14.9 & 15.4 & 15.4 & 14.8 & 13.7 & 12.7 & 12.1 & 11.9 & 12.7 & 13.9 & 14.6 & 13.3 & 12.9\end{array}$

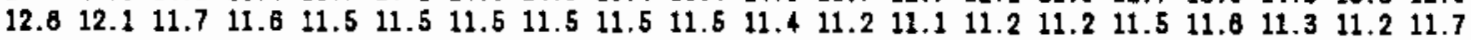

$\begin{array}{llllllllllllllllllllllll}14.6 & 15.7 & 15.6 & 14.9 & 14.3 & 13.7 & 13.2 & 13.5 & 14.3 & 15.6 & 15.2 & 14.8 & 13.7 & 12.8 & 12.6 & 12.7 & 14.6 & 14.2 & 13.4 & 12.8\end{array}$

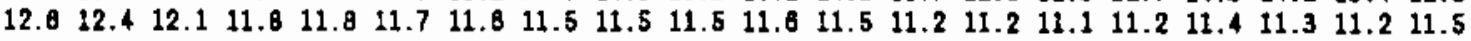

$\begin{array}{lllllllllllllllllllllllll}13.1 & 15.6 & 16.8 & 17.1 & 18.2 & 15.6 & 13.8 & 13.1 & 13.1 & 13.8 & 14.4 & 14.9 & 14.4 & 12.9 & 12.2 & 12.8 & 14.1 & 14.4 & 13.3 & 12.4\end{array}$

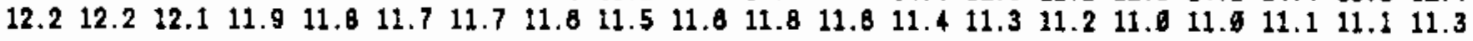

$\begin{array}{llllllllllllllllllllllll}11.8 & 12.7 & 14.7 & 17.2 & 18.2 & 17.6 & 15.9 & 14.3 & 13.4 & 13.1 & 13.5 & 14.2 & 14.8 & 13.6 & 12.4 & 12.8 & 13.9 & 14.4 & 13.8 & 12.6\end{array}$

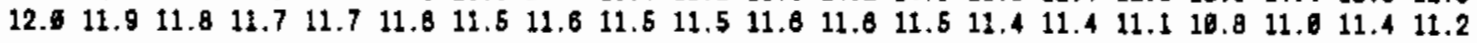

$\begin{array}{lllllllllllllllllllllll}16.8 & 11.8 & 12.3 & 14.4 & 16.7 & 18.5 & 18.8 & 17.0 & 15.6 & 14.3 & 14.2 & 14.4 & 14.7 & 14.4 & 13.3 & 12.8 & 13.3 & 13.8 & 13.8 & 13.6\end{array}$

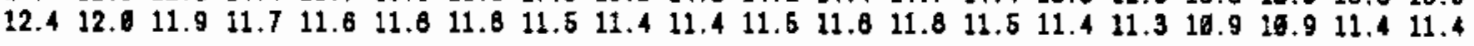

$\begin{array}{lllllllllllllllllllllllllll}10.3 & 11.3 & 11.6 & 12.6 & 14.0 & 15.4 & 17.9 & 19.3 & 17.7 & 18.3 & 16.1 & 15.7 & 15.4 & 15.2 & 14.4 & 13.6 & 13.2 & 13.2 & 13.1 & 12.8\end{array}$

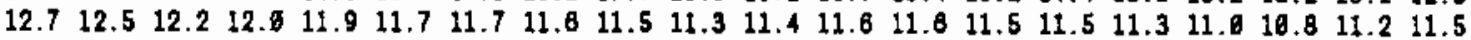

$\begin{array}{lllllllllllllllllllllll}9.9 & 10.8 & 11.4 & 11.8 & 12.4 & 12.7 & 14.1 & 17.2 & 18.6 & 18.0 & 17.7 & 17.8 & 18.9 & 16.3 & 15.4 & 14.5 & 13.8 & 13.8 & 13.8 & 13.2\end{array}$

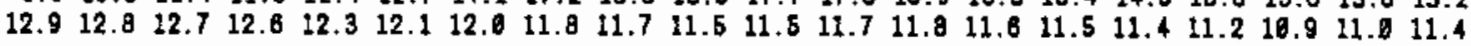

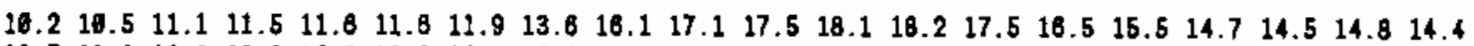

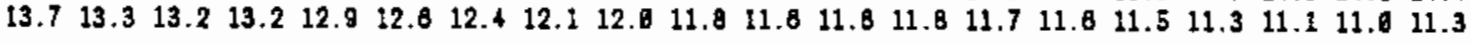

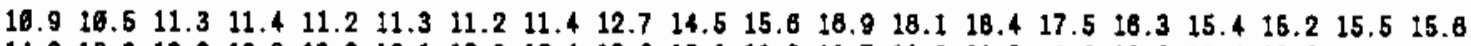
$\begin{array}{lllllllllllllllllllll}14.8 & 13.8 & 13.3 & 13.3 & 13.3 & 13.1 & 12.8 & 12.4 & 12.2 & 12.1 & 11.8 & 11.7 & 11.8 & 11.8 & 11.6 & 11.8 & 11.4 & 11.2 & 11.1 & 11.2\end{array}$

$\begin{array}{llllllllllllllllllllll}11.6 & 11.0 & 11.7 & 11.8 & 11.0 & 10.9 & 10.9 & 19.5 & 10.6 & 12.1 & 13.7 & 15.1 & 16.9 & 18.4 & 18.2 & 16.8 & 16.5 & 15.1 & 15.8 & 16.4\end{array}$

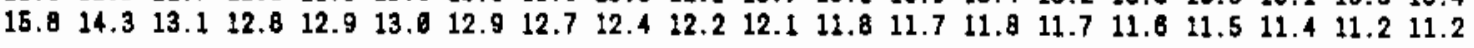

$\begin{array}{lllllllllllllllllllllll}12.1 & 11.8 & 12.5 & 12.5 & 11.2 & 10.5 & 10.6 & 16.2 & 9.8 & 10.2 & 11.9 & 13.3 & 15.0 & 17.3 & 18.6 & 17.4 & 15.3 & 14.4 & 15.4 & 17.1\end{array}$

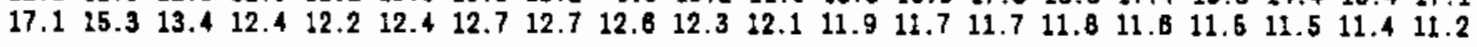

$\begin{array}{lllllllllllllllllllllllll}11.6 & 12.4 & 13.1 & 13.3 & 11.9 & 10.5 & 16.2 & 10.2 & 9.8 & 9.4 & 10.4 & 11.8 & 13.2 & 15.2 & 17.4 & 18.1 & 16.0 & 13.8 & 14.2 & 16.7\end{array}$ $\begin{array}{lllllllllllllllllllllll}18.1 & 17.6 & 14.7 & 13.0 & 12.2 & 12.6 & 12.3 & 12.7 & 12.7 & 12.5 & 12.3 & 12.1 & 11.8 & 11.6 & 11.7 & 11.7 & 11.7 & 11.8 & 11.5 & 11.3\end{array}$

$\begin{array}{lllllllllllllllllllllll}19.2 & 11.8 & 13.1 & 13.7 & 13.1 & 11.6 & 19.4 & 10.3 & 10.1 & 9.5 & 9.7 & 10.7 & 12.9 & 13.4 & 15.1 & 16.7 & 18.5 & 14.4 & 13.2 & 15.4\end{array}$ $\begin{array}{llllllllllllllllllll}17.6 & 18.2 & 16.7 & 14.5 & 13.2 & 12.4 & 12.4 & 12.8 & 13.1 & 12.8 & 12.4 & 12.2 & 11.9 & 11.7 & 11.7 & 11.7 & 11.9 & 11.8 & 11.5 & 11.3\end{array}$

$\begin{array}{lllllllllllllllllllllllll}9.8 & 10.6 & 12.4 & 13.5 & 13.5 & 12.7 & 11.3 & 18.5 & 10.8 & 16.2 & 9.5 & 16.2 & 11.3 & 12.2 & 13.6 & 15.0 & 15.9 & 13.6 & 12.2 & 13.5\end{array}$

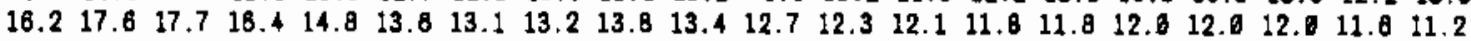

$\begin{array}{lllllllllllllllllllllllll}10.8 & 9.5 & 16.9 & 12.8 & 13.1 & 13.2 & 12.2 & 11.0 & 13.3 & 11.3 & 10.1 & 18.1 & 11.6 & 11.4 & 12.3 & 13.8 & 13.8 & 12.4 & 11.9 & 12.0\end{array}$

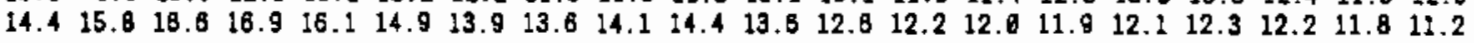

$\begin{array}{lllllllllllllllllllllllll}12.1 & 9.8 & 9.7 & 11.2 & 12.2 & 12.7 & 12.5 & 11.5 & 11.2 & 11.9 & 11.3 & 16.5 & 19.9 & 11.3 & 11.7 & 12.4 & 12.7 & 12.8 & 12.0 & 11.5\end{array}$ $13.613 .9 \quad 14.4 \quad 14.8 \quad 14.9 \quad 14.6 \quad 33.9 \quad 13.3 \quad 13.8 \quad 14.5 \quad 14.5 \quad 13.4 \quad 12.6 \quad 12.2 \quad 12.012 .1 \quad 12.4 \quad 12.412 .1 \quad 11.5$

$\begin{array}{lllllllllllllllllllllllll}13.2 & 11.0 & 10.0 & 10.5 & 11.4 & 12.0 & 12.1 & 11.6 & 11.3 & 11.6 & 11.8 & 11.1 & 11.1 & 11.4 & 11.6 & 12.6 & 12.2 & 12.0 & 11.6 & 11.7\end{array}$

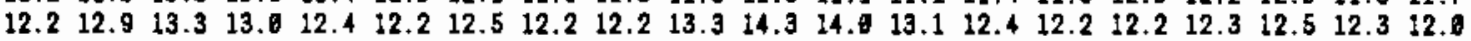

$\begin{array}{llllllllllllllllllll}13.8 & 12.3 & 11.2 & 11.8 & 11.3 & 11.6 & 11.8 & 11.8 & 11.7 & 11.6 & 11.4 & 11.2 & 11.1 & 11.3 & 11.6 & 12.1 & 12.4 & 12.5 & 12.5 & 12.6\end{array}$

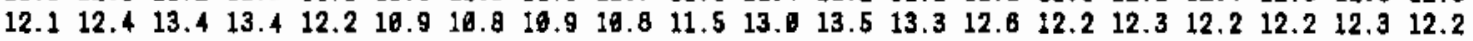

$\begin{array}{llllllllllllllllllll}14.1 & 13.1 & 12.4 & 11.8 & 11.8 & 11.7 & 11.7 & 11.8 & 12.3 & 12.3 & 11.7 & 11.4 & 11.2 & 11.2 & 11.6 & 12.1 & 12.8 & 13.6 & 13.1 & 13.5\end{array}$

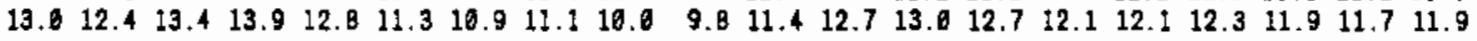

$\begin{array}{lllllllllllllllllllllllllll}13.9 & 13.5 & 13.3 & 12.7 & 12.9 & 11.9 & 12.0 & 11.8 & 12.3 & 12.9 & 12.4 & 11.9 & 11.5 & 11.3 & 11.7 & 12.3 & 12.8 & 13.1 & 13.5 & 14.2\end{array}$ $\begin{array}{lllllllllllllllllllll}14.2 & 13.6 & 13.0 & 13.8 & 13.3 & 12.3 & 11.9 & 12.2 & 11.1 & 9.4 & 9.8 & 11.4 & 12.5 & 12.8 & 12.4 & 12.1 & 12.3 & 12.1 & 11.4 & 11.8\end{array}$ 
$\begin{array}{lllllllllllllllllllllll}13.5 & 13.3 & 13.4 & 12.8 & 12.3 & 12.2 & 12.4 & 11.9 & 11.9 & 12.8 & 12.9 & 12.5 & 12.9 & 11.4 & 11.7 & 12.5 & 12.8 & 13.9 & 13.4 & 14.4\end{array}$ $\begin{array}{llllllllllllllllllllll}15.3 & 13.9 & 12.8 & 12.8 & 13.6 & 12.9 & 13.6 & 13.2 & 12.8 & 16.9 & 9.5 & 10.1 & 11.4 & 12.2 & 12.5 & 12.3 & 12.4 & 12.6 & 11.9 & 10.5\end{array}$

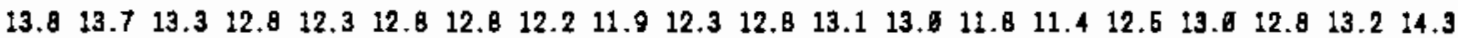
$\begin{array}{llllllllllllllllllllllll}15.5 & 14.9 & 13.2 & 12.3 & 11.8 & 12.0 & 13.6 & 13.7 & 13.6 & 12.7 & 11.5 & 16.8 & 16.7 & 11.2 & 12.2 & 12.8 & 12.8 & 12.9 & 12.2 & 16.6\end{array}$

$\begin{array}{lllllllllllllllllllllll}13.9 & 14.3 & 13.6 & 12.5 & 12.2 & 13.2 & 13.5 & 12.6 & 12.1 & 11.9 & 12.0 & 13.6 & 13.7 & 12.8 & 11.4 & 12.0 & 12.9 & 12.8 & 13.0 & 14.2\end{array}$

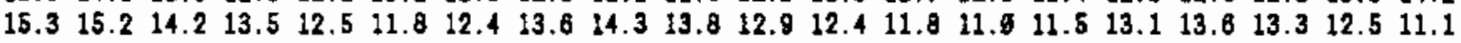

$\begin{array}{lllllllllllllllllllllll}13.1 & 14.3 & 14.0 & 13.4 & 13.9 & 13.5 & 14.1 & 13.6 & 12.9 & 12.6 & 12.6 & 11.9 & 13.2 & 13.6 & 12.3 & 11.6 & 12.2 & 12.4 & 12.5 & 13.5\end{array}$ $\begin{array}{llllllllllllllllllllllll}14.8 & 15.3 & 15.1 & 15.1 & 14.8 & 14.6 & 13.5 & 13.8 & 14.8 & 15.6 & 14.6 & 14.6 & 13.5 & 12.7 & 12.0 & 12.7 & 13.7 & 14.8 & 13.5 & 12.2\end{array}$

END OF DISSPL 10.0 - 9969 VECTORS IN 1 PLOTS.

RUN ON B/1/86 LSING SERIAL NLABER 60 AT BATTELE NORTHWET

PROPRIETARY SOFTTARE PRODUCT OF ISSCO, SAN DIEGO, CALIF.

208463 VIRTJAL STDRAGE REFERENCE; 5 READS; WRITES. 



\section{$\underline{\text { DISTRIBUTION }}$}

No. of

Copies

OFFSITE

Carl Aspliden

Battelle Memorial Institute

Washington Office

2030 M Street, NW

Washington, DC 20036

J. Cadogan

U.S. Department of Energy

Wind/Ocean Technologies Division

1000 Independence Avenue

Forrestal Building, Room $5 \mathrm{H} 048$

Washington, DC 20585

D. F. Ancona

U.S. Department of Energy

Wind/Ocean Technologies Division

1000 Independence Avenue

Forrestal Building, Room $5 \mathrm{H} 048$

Washington, DC 20585

G. P. Tennyson

U.S. Department of Energy

Albuquerque Operations Office

P.0. Box 5400

Albuquerque, NM 87110

30 DOE Technical Information Center

George Bergeles

National Technical University

of Athens

Dept. of Mechanical Engineering

42, Patission Street

GR I04 33 Athens

GREECE

Earl L. Davis

U.S. Windpower, Inc.

2305 S. Vasco Road

Livermore, CA 94550
No. of

Copies

Dr. Edgar DeMeo

Electric Power Research Institute

$3412 \mathrm{Hillview}$ Avenue

Palo Alto, CA 94303

Phillip French

NASA Scientific and Technical

Information Facility

P.0. Box 8757

Baltimore/Washington International Airport

Baltimore, MD 21240

Frank Goodman, Jr.

Electric Power Research Institute $3412 \mathrm{Hillview}$ Avenue

Palo Alto, CA 94303

Tom Gray

American Wind Energy Association

$1516 \mathrm{King}$ Street

Alexandria, VA 22314

Tom Hiester

Flow Industries, Inc.

Kent, WA 98031

Ron Holeman

Bonneville Power Administration

Generation Engineering

P.0. Box 3621

Portland, OR 97208

W. D. Johnston

Hawaijan Electric Company, Inc.

P.0. Box 2750

Honolulu, HI 96840

R. H. Kirchhoff

Department of Mechanical Engineering

University of Massachusetts

Amherst, MA 01003 
No. of

Copies

P. Kl jmas

Sandia Laboratories

Division 5443, P.0. Box 5800

Albuquerque, NM 87115

Leif Kristensen

Department of Physics

Ris $\varnothing$ National Laboratory

4000 Roskilde

DENMARK

D. Lindley

Taylor Woodrow Construction, Ltd. Taywood House

345 Ruislip Road

Southall

Middlesex UBI 2QX

ENGLAND

Peter Lissaman

Aerovironment, Inc.

$145 \mathrm{Vista}$ Avenue

Pasadena, CA 91107

Robert Noun

Solar Energy Research Inst tute

1617 Cole Boulevard

Golden, Co 80401

G. T. Phillips

Science Applications, Inc.

1200 Prospect Street

La Jolla, CA 92038

Farrell Smith Seiler

Wind Energy News Service

P.0. Box 4008

St. Johnsbury, VT 05819

David Spera

NASA/Lewis Research Center

21000 Brookpark Road

Cleveland, $\mathrm{OH} 44135$

Robert Thresher

Solar Energy Research Institute

1617 Cole Boulevard

Golden, co 80401
No. of

Copies

Andrew Trenka

Solar Energy Research Institute

1617 Cole Boulevard

Golden, CO 80401

W. A. Vachon

P.0. Box 149

Manchester, MA 01944

Scott Veenhuizen

United Industries Corporation

12835 Bell-Red Road, Suite 20

Bellevue, WA 98005

H. L. Wegley

21414 68th Avenue, S.

Kent, WA 98032

Robert Wilson

Department of Mechanical

Engineering

Oregon State University

Corvallis, OR 97331

Andy Zalay

American Diversified

Tech Division

3200 Park Center

Costa Mesa, CA 92626

ONSITE

DOE Richland Operations Office

J. J. Sutey/D. R. Segna 
No. of

Copies

32 Pacific Northwest Laboratory

J. C. Barnard (5)

J. W. Buck

J. R. Connel]

D. W. Dragnich

C. E. Elderkin

D. L. Elliott

J. M. Hales

P. C. Hays

M. E. Hinchee

A. H. Miller

V. R. Morris

E. L. Owczarski

D. C. Powell

J. A. Stottlemyre

T. K. Thompson

L. L. Wendel 1

R. E. Wildung

Technical Information $\mathrm{Files}$ (5)

Publishing Coordination (2)

WCPE Program Office (5) 
